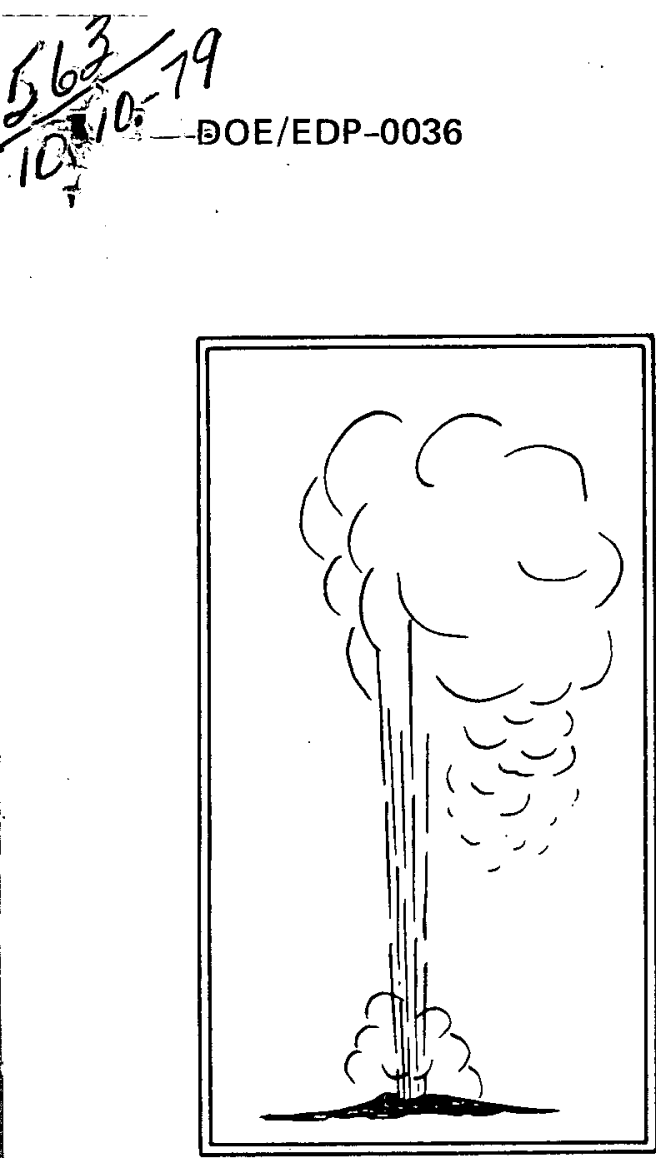

\title{
ENVIRONMENTAL DEVELOPMENT PLAN GEOTHERMAL ENERGY SYSTEMS
}

August 1979

\section{U.S. Department of Energy}

Assistant Secretary for Energy Technology Assistant Secretary for Environment 


\section{DISCLAIMER}

This report was prepared as an account of work sponsored by an agency of the United States Government. Neither the United States Government nor any agency Thereof, nor any of their employees, makes any warranty, express or implied, or assumes any legal liability or responsibility for the accuracy, completeness, or usefulness of any information, apparatus, product, or process disclosed, or represents that its use would not infringe privately owned rights. Reference herein to any specific commercial product, process, or service by trade name, trademark, manufacturer, or otherwise does not necessarily constitute or imply its endorsement, recommendation, or favoring by the United States Government or any agency thereof. The views and opinions of authors expressed herein do not necessarily state or reflect those of the United States Government or any agency thereof. 


\section{DISCLAIMER}

Portions of this document may be illegible in electronic image products. Images are produced from the best available original document. 


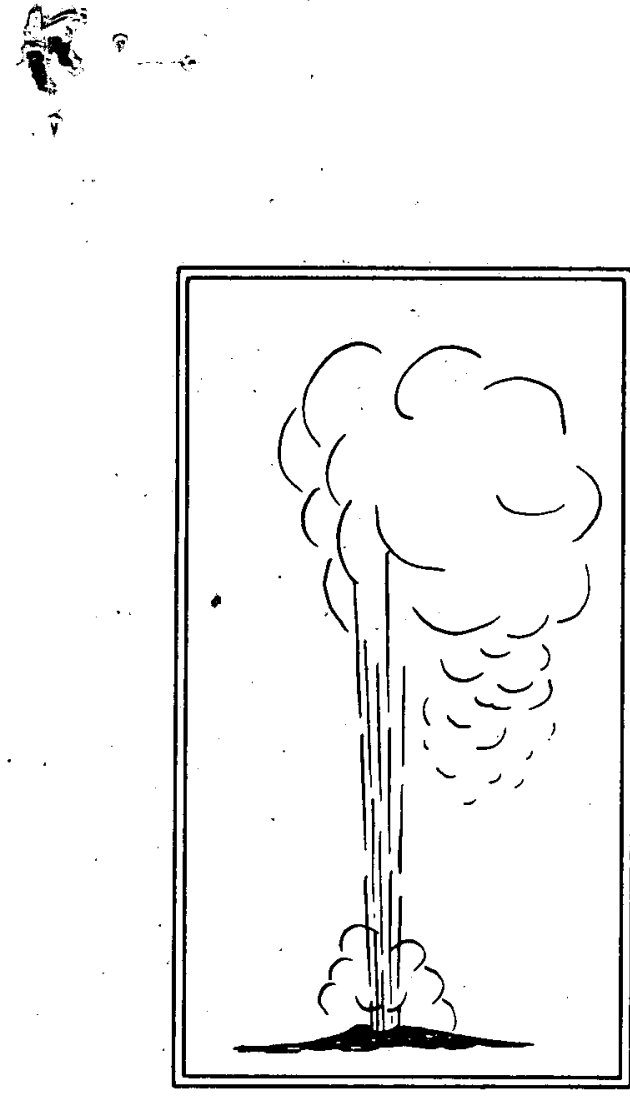

DOE/EDP-0036

UC-11, 41, 64

\section{ENVIRONMENTAL DEVELOPMENT PLAN GEOTHERMAL ENERGY SYSTEMS}

\section{August 1979}
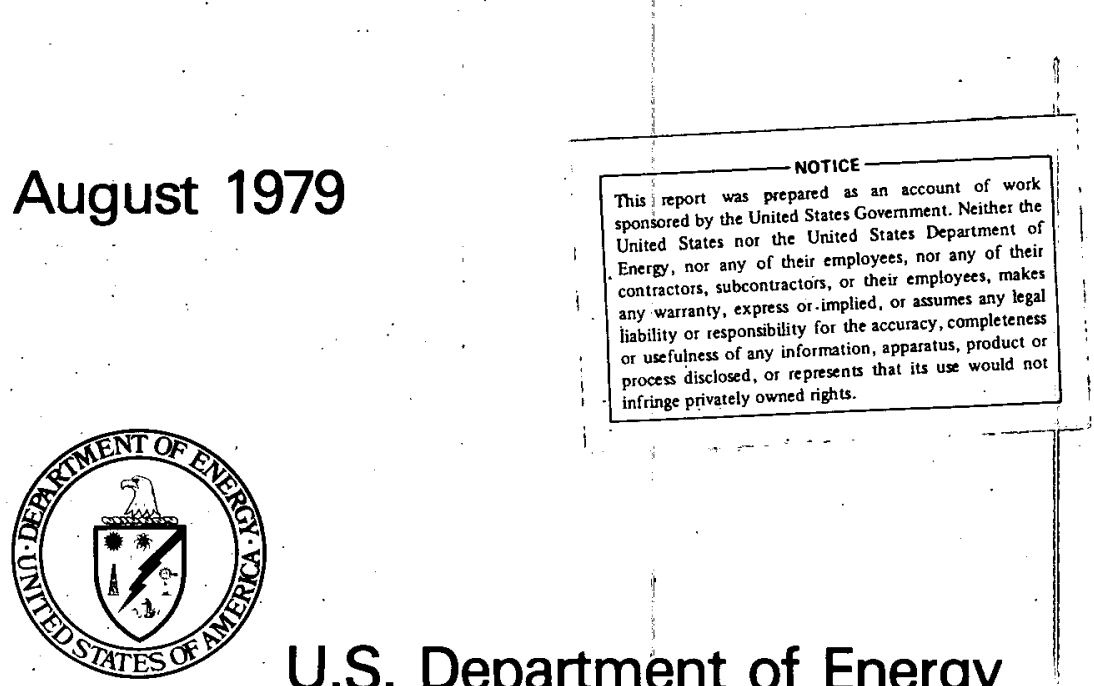

\section{U.S. Department of Energy}

Assistant Secretary for Energy Technology Assistant Secretary for Environment Washington, D.C. 20585 
Avallable from:

National Technical Information Service (NTIS)

U.S. Department of Commerce

5285 Port Royal Road

Springfield, Virginia 22161

Price: Printed Copy: $\quad \$ 6.00$

Microfiche: $\quad \$: 3.00$ 


\section{FOREWORD}

Environmental Development Plans (EDPs) are prepared by the Department of Energy (DOE) to help fulfill the Department's responsibility for the development of environmentally acceptable energy technologies. The EDP provides a common basis for planning, managing, and reviewing all environmental aspects of the energy programs under DOE's jurisdiction.

The EDP is timed to precede key technology program decisions as the technology moves from the exploratory development stage to an engineering development or technology demonstration phase. To ensure that environmental, health, and safety (EH\&S) considerations will be addressed adequately in the technology decisionmaking process, the EDP (1) identifies and evaluates EH\&S concerns; (2) defines EH\&S reseách and related assessments to examine or resolve the concerns; (3) provides a coordinated schedule with the technology program for required EH\&S research and development; and (4) indicates the timing for Environmental Assessments, Environmental Impact Statements, Environmental Readiness Documents, and Safety Analysis Reports.

'The initial EDP for Geothermal Energy Systems (DOE/EDP-0014) was published in March 1978. This EDP provides a substantial updating of the 1978 document. It draws on analysis contained in the Environmental Readiness Document (ERD) for Hydrothermal Electric and Direct Heat (DOE/ERD-0005). ERDs are assessments prepared independently by the Office of Environment to provide a critical review of the environmental readiness of a technology.

The revised EDP on Geothermal Energy Systems is being released under authority of DOE Order 5420.1 dated August 10, 1978. It was prepared jointly by the Division of Planning and Technology Transfer (ET) and the Technology Assessment Division (EV), with the assistance of the research and support divisions of the Office of Environment.

This EDP on Geothermal Energy Systems is being distributed so that everyone having interests and responsibilities with respect to geothermal energy systems may have the opportunity to review and provide suggested - changes for future updates.
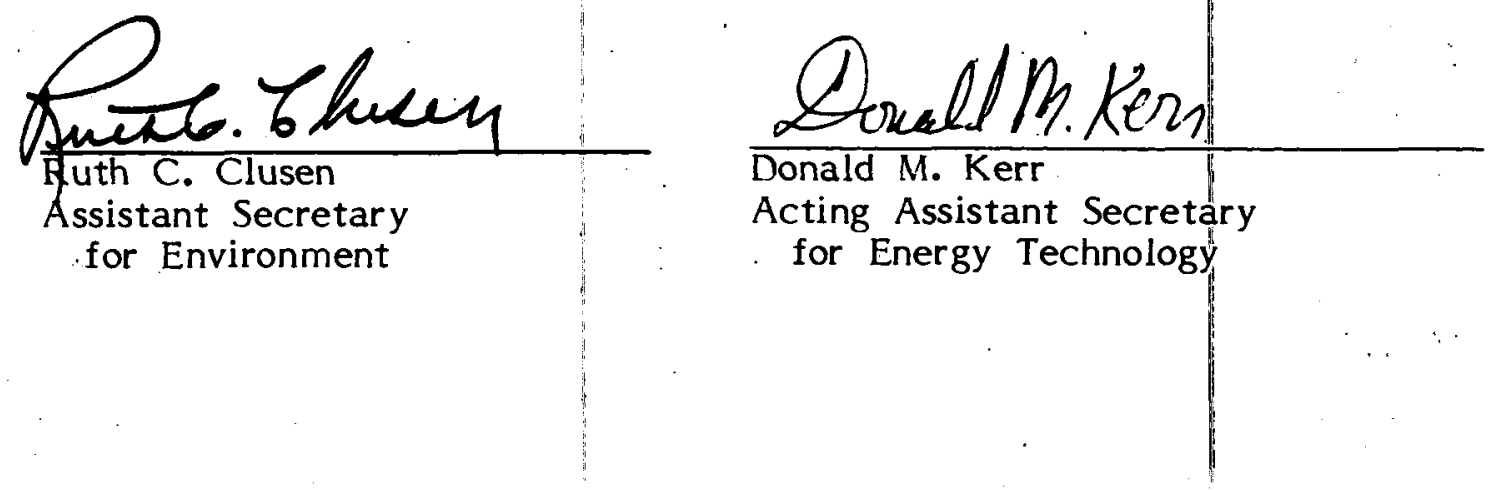


CONTENTS

I. SUMMARY ...................... . . 1

II. TECHNOLOGY PROGRAM . . . . . . . . . . . . . . . 3

A. Technology Description . . . . . . . . . . . . 3

1. Hydrothermal Systems . . . . . . . . . . 3

2. Geopressured Systems ............. 3

3. Hot Dry Rock Systems. . . . . . . . . . . 3

B. Program Description and Milestones ... . . . . . 6

1. Federal Program. .. . . . . . . . . . 6

2. Geothermal Loan Guaranty Program. . . . . . 8

III. ENVIRONMENTAL CONCERNS AND REQUIREMENTS ........................ . . 17

A. Introduction . . . . . . . . . . . . . . . . . 17

B. Analysis of Concerns and Research

Requirements. . . . . . . . . . . . . . . . . . . . 17

C. Hydrothermal Systems: Concerns, Requirements,

and Status ................... . 18

1. Release of Airborne Effluents... . . . . . . 18

2. Release of Waterborne Effluents . . . . . . . . 27

3. Noise. . . . . . . . . . . . . . . 28

4. Subsidence . . . . . . . . . . . . . 28

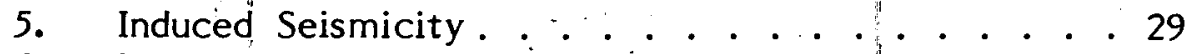

6. Water Use . . . . . . . . . . . . 30

7. Land Use . . . . . . . . . . . . . . . . . 30

8. Social Services and Community Structure . . . . 31

9. System Safety and Occupational Health. . . . . 32

D. Geopressured Systems: Concerns, Requirements,

and Status . . . . . . . . . . . . . . . . . 32

1. Release of Airborne Effluents . . . . . . . 32

2. Release of Waterborne Effluents . . . . . . . 38

3. Noise . . . . . . . . . . . . . . . . 38

4. Subsidence . . . . . . . . . . . . . 38

5. Induced Seismicity. . . . . . . . . . . . . 39

6. Water Use . . . . . . . . . . . . . . . . . . . 39

7. Land Use ... . . . . . . . . . . . . . . . . . . 39

8. Social Services and Community Structure . . . . 39

9. System Safety and Occupational Health . . . . 39 
E. Hot Dry Rock Systems: Concerns, Requirements, and Status .................. . 40

1. Release of Airborne Effluents :. . . ..... . 40

2. Release of Waterborne Effluents . . . . . . . 40

3. Noise . . . . . . . . . . . . . . . 40

4. Subsidence :............... 40

5. Induced Seismicity ............. 45

6. Water Use . . . . . . . . . . . . . . . 45

7. Land Use. . . . . . . . . . . . . . . . 45

8. Social Services and Community Structure . . . . 45

9. System Safety and Occupational Health . . . . . 45

IV. ENVIRONMENTAL PROGRAM STRATEGY AND

MANAGEMENT ..................... . . 46

A. Program Goal ................. . 46

B. Program Strategy .. . . . . . . . . . . . . . 46

C. Program Management. . . . . . . . . . . . . . 47

1. Responsibility. . . . . . . . . . . . . 47

2. Coordination ............... . 50

3. Management Documents .......... 50

BIBLIOGRAPHY . . . . . . . . . . . . . . . 52

APPENDIX A. Setting Research Priorities for Environmental, Health, and Safety Research. . . . . . . . 55

APPENDIX B. Summary of Completed, Current, and Planned Environmental Research Projects... . . . 57

GLOSSARY . . . . . . . . . . . . . . . . . . . 71 
The Environmental Development Plan (EDP) system is designed to provide a common basis for planning, managing, and reviewing the environmental aspects of the various energy technology programs under the Department of Energy's (DOE) jurisdiction. For a specified technology development program, the EDP performs the following functions:

- Governs the nature and content of the Environmental Issues and Control Technology annex to the Energy System Acquisition Project Plan, which is the baseline management: document for DOE project activities; $*$

- Summarizes the environmental concerns associated with technology development, demonstration, and commercialization identified and evaluated in the previous EDP and the Environmental Readiness Document (ERD)** if one has been prepared;

- Defines general requirements for environmental, health, $\therefore$ and safety research and assessments to resolve these concerns and defines an implementation strategy;

- Provides a coordinated timing schedule for required environmental research and development ( $R \& D$ ), technology program activities, and decision points; and

- Indicates approximate timing for documents required in the National Environmental Policy Act (NEPA) process, ERDs, and safety analyses where appropriate.

The publication of an EDP is generally timed to precede key technology program decisions that result in program shifts from an exploratory development into the technology development, engineering development, demonstration, or commercialization phase. The time frame covered by an EDP generally encompasses all significant decision points relating to the technology program. Projects or subprograms that are likely to result in a demonstration or commercialization within the near term are presented in detail. Projects that will need to be considered in greater detail in the next EDP update are identified.

*"Program and Project Management System for DOE Outlay Programs;" memorandum from Dale D. Myers, Under Secretary, Department of Energy, May $31,1978$.

**The ERD is an independent evaluation by the Office of Environment which analyzes a technology's environmental acceptability. 
This EDP for geothermal energy systems covers all current and planned activities of the DOE Geothermal Energy Systems Program. The goal of this program is to provide those initiatives which are needed to accelerate commercial development of geothermal resources and to ensure environmental and social acceptability and operational safety. Major elements of this program include exploration of resources, confirmation of reservoirs, development of energy extraction systems, demonstration of utilization systems, identification and removal of institutional barriers, and a loan guaranty program.

Three types of geothermal resources are covered in this EDP: hydrothermal convection systems, geopressured systems, and hot dry rock systems. Of these three, only hydrothermal convection systems are considered ready for commercial development, and an ERD for these systems has been published. The other two systems show promise of future development, but current research is now oriented : toward resource exploration and confirmation and toward small-scale experiments of heat extraction systems. The geopressured resource is projected to contain large amounts of dissolved methane. The recovery of this methane is part of the geothermal geopressured program.

Environmental concerns and requirements for resolution of these concerns are discussed at length in Section III. In terms of immediate need and importance in getting power online, the emission of $\mathrm{H}_{2} \mathrm{~S}$ is the most important concern and the demonstration of an effective abatement system is the most significant requirement. Demonstration of one such system is targeted for FY 1979 at The Geysers geothermal area. Other significant concerns are the management or disposal of spent geothermal fluids, the potential of land subsidence, questions of water availability for heat rejection systems, land use conflicts, and socioeconomic and cultural problems. The requirements to appropriately research and mitigate these and other concerns in time to permit orderly and timely. development of geothermal energy systems are scheduled in this EDP. 


\section{A. TECHNOLOGY DESCRIPTION}

Geothermal resources of near-term interest are of three types: hydrothermal, geopressured, and hot dry rock.

\section{Hydrothermal Systems}

Hydrothermal systems are convective systems of water and steam that are trapped in fractured rocks or permeable sediments by impermeable surface layers. Geothermal fluids may be released when such systems are tapped by drilling. A specific resource is classified as being either vapor- or liquid-dominated, according to the state of the fluid produced." Typical electrical power generation systems for high-temperature resources are shown schematically in Figures 2-1 (a) and (b). A closed binary system schematic for moderate temperature hydrothermal resources is shown in Figure $2-1$ (c).

Hydrothermal resources have high potential for near-term commercial development. For example, vapor-dominated resources are presently being used for the generation of electricity in the United States, Japan, and Italy; liquid-dominated resources are in use in Iceland, Mexico, El Salvador, Russia, and New Zealand.

\section{Geopressured Systems}

Geopressured zones consist of highly porous sands saturated with saline water at very high pressure and temperature. The high temperature is thought to be the result of normal heat flow being trapped by uncompacted clays 'which 'serve as' insulating layers. 'Waters derived from the compaction and dehydration of clays accumulate in the sands and greatly increase the fluid reserve. The marine sediments are under-compacted below depths of 6,500 to 10,000 feet, and the interstitial fluid carities part of the overburden load (i.e., the fluids are at pressures between the hydrostatic and the lithostatic head). Temperatures up to $290^{\circ} \mathrm{C}$ and pressures up to 1000 atmospheres have been measured in these systems. In the United States, the principal geopressured formations are located under the gulf coast of Texas and Louisiana. The magnitude of the resource is substantial, and its economic value is enhanced by the presence of natural gas dissolved in the geopressured fluid; however, difficult technical and economic problems must be solved before geopressured resources can be utilized commercially. A proposed system for generating electricity and recovering methane is shown in Figure 2-2.

\section{Hot Dry Rock Systems}

Hot dry rock resources are those geothermal reservoirs where the heat is contained in rock of low permeability. Hot dry rock systems are potentially the largest and most widely distributed geothermal resource in the 


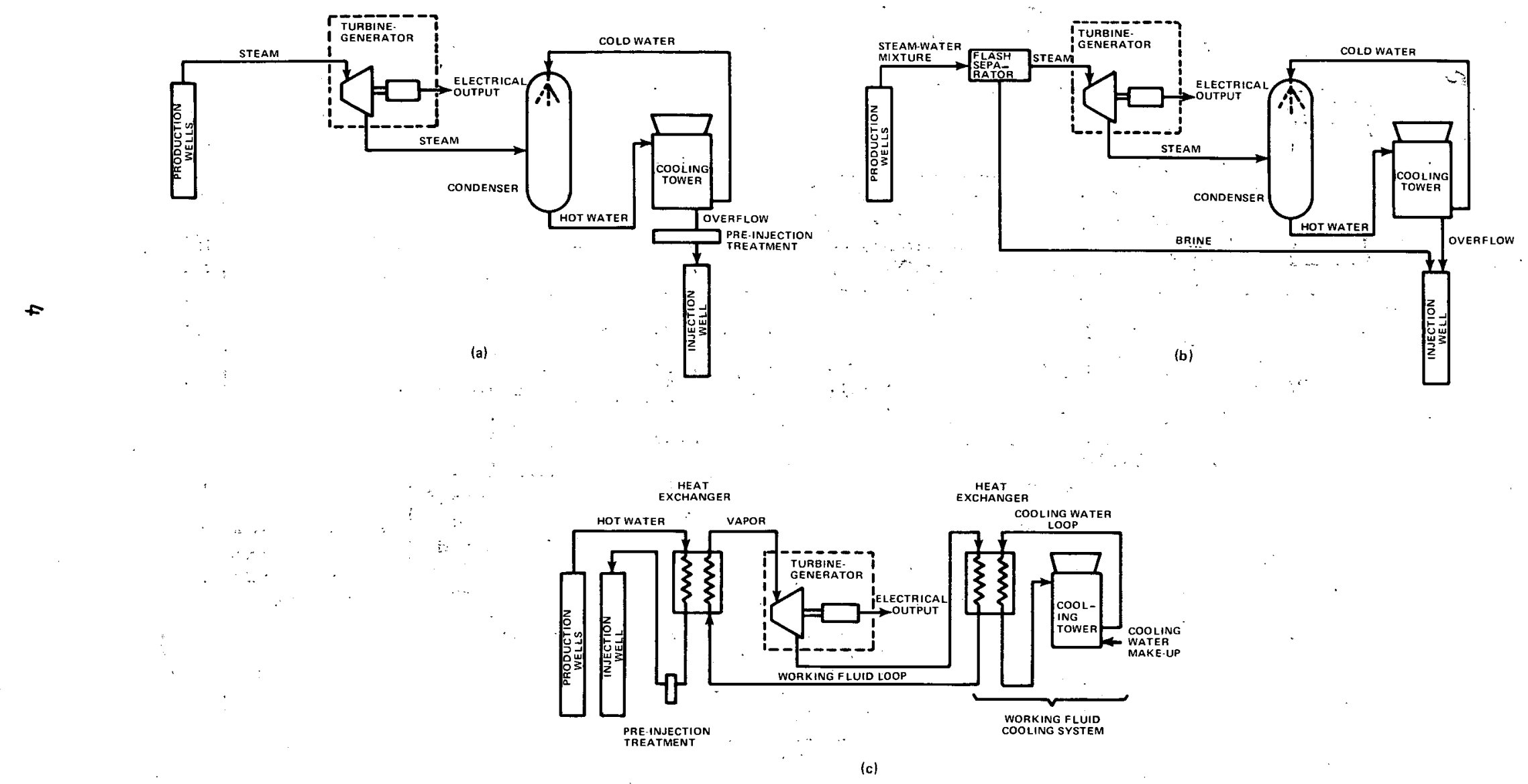

Figure 2-1. Electrical Power Generation From (a) a Vapor-Dominated Resource, (b) a Liquid-Dominated Resource, and (c) a Closed Binary System From a Hydrothermal Resource 


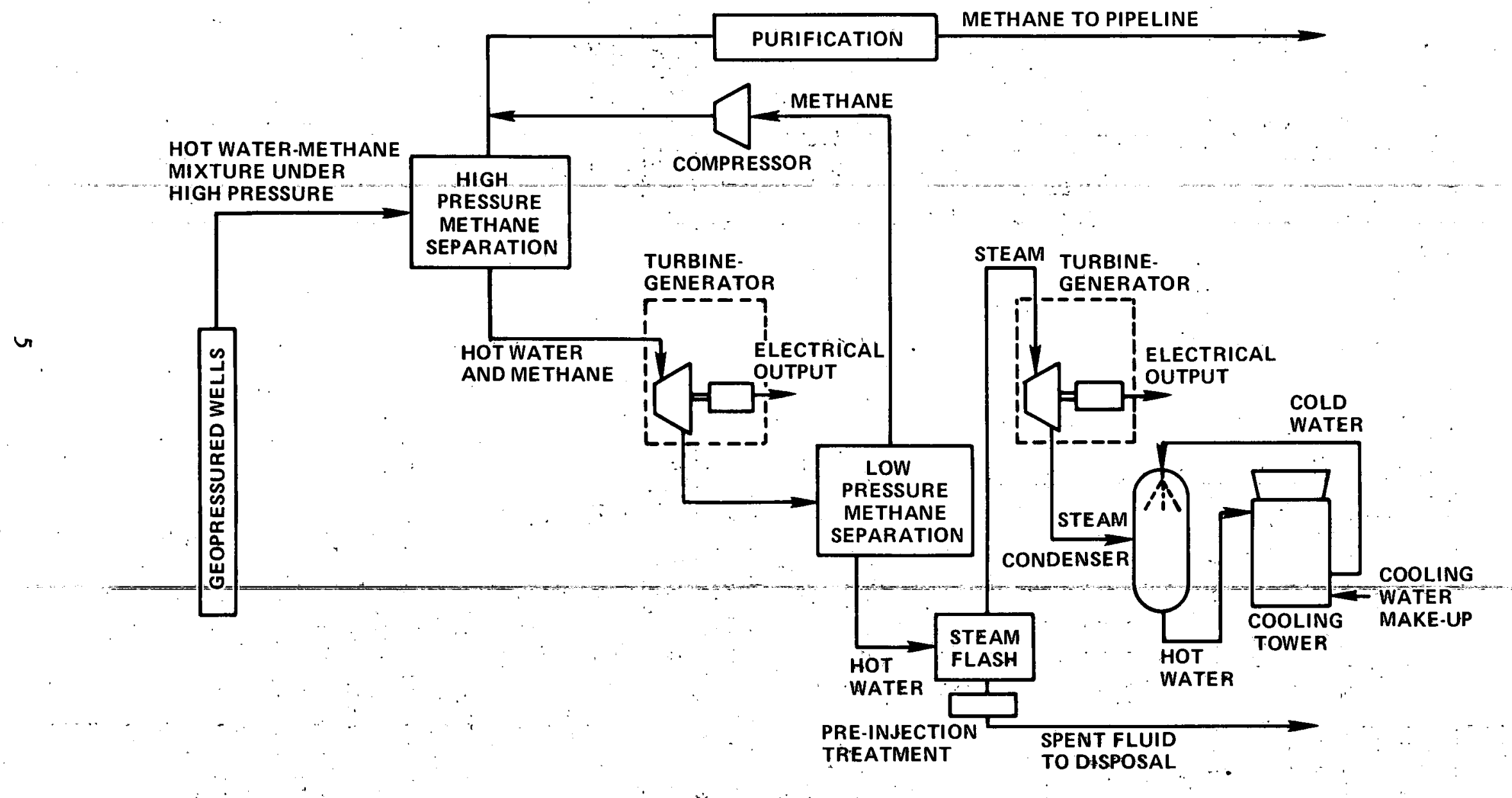

Figure 2-2. Electrical Power Generation and Methane Production From Geopressured Resource 
Nation. A large volume of hot dry rock (normal gradient resource) is located in the Earth's crust at depths in excess of $15 \mathrm{~km}(50,000 \mathrm{ft})$, which is beyond present drilling capability. However, the volume of hot dry rock at more shallow, accessible depths is also considerable. It is estimated that 95,000 square miles of the Western Heat Flow Province (the 13 Rocky Mountain and Pacific Coast States) are underlain by hot dry rock at temperatures greater than $29.3^{\circ} \mathrm{C}$ at depths less than $5 \mathrm{~km}(16,000 \mathrm{ft})$. Two specific promising areas are the Valles Caldera, near Los Alamos, New Mexico, and the Coso Hot Springs, near China Lake, California. Other potential sites being evaluated are located on the eastern coastal plain, the midwestern region, and the Pacific Coast.

Development of these resources requires drilling into the rock, inducing fractures, injecting fluid, and removing the resultant heated fluid through separate wells. Technical.problems associated with fracturing and maintaining the fractures must be solved before these resources can be developed commercially. A system for extracting energy proposed for the Fenton Hill area near Los Alamos is shown in Figure 2-3.

\section{B. PROGRAM DESCRIPTION AND MILESTONES}

The DOE program management for geothermal energy research, development, demonstration, and commercialization is the responsibility of the Office of Energy Technology (ET) and the Office of Resource Applications (RA), with program implementation carried out by the Division of Geothermal Energy/ET and the Division of Geothermal Resource Management/RA. DOE has been established as the lead agency for coordinating the Federal geothermal energy program. The goal of this Federal program is to enable and stimulate commercial and industrial development and use of the Nation's geothermal resources in an environmentally and socially acceptable manner. This development and use are to encompass both generation of electricity and the direct thermal energy use of geothermal resources, as well as methane extraction from the gulf coast geopressured geothermal resource.

\section{Federal Program}

The Federal geothermal program is directed toward providing those initiatives that are needed to effect accelerated commercial development while maintaining environmental acceptability and operational safety. It involves the activities of several agencies including DOE, the Department of the Interior (DOI), the Department of Agriculture, the Environmental Protection Agency (EPA), and others. DOE has the responsibility for coordinating the program and for coordinating the formulation of national goals for geothermal development. Coordination is accomplished through the Interagency Geothermal Coordinating Council (Figure 2-4). The achievement of environmental acceptability and operational safety through laws and regulations is the responsibility of several agencies: DOE, DOI, EPA, the Council on Environmental Quality, and the Occupational Safety and Health Administration (Figure 2-5). 


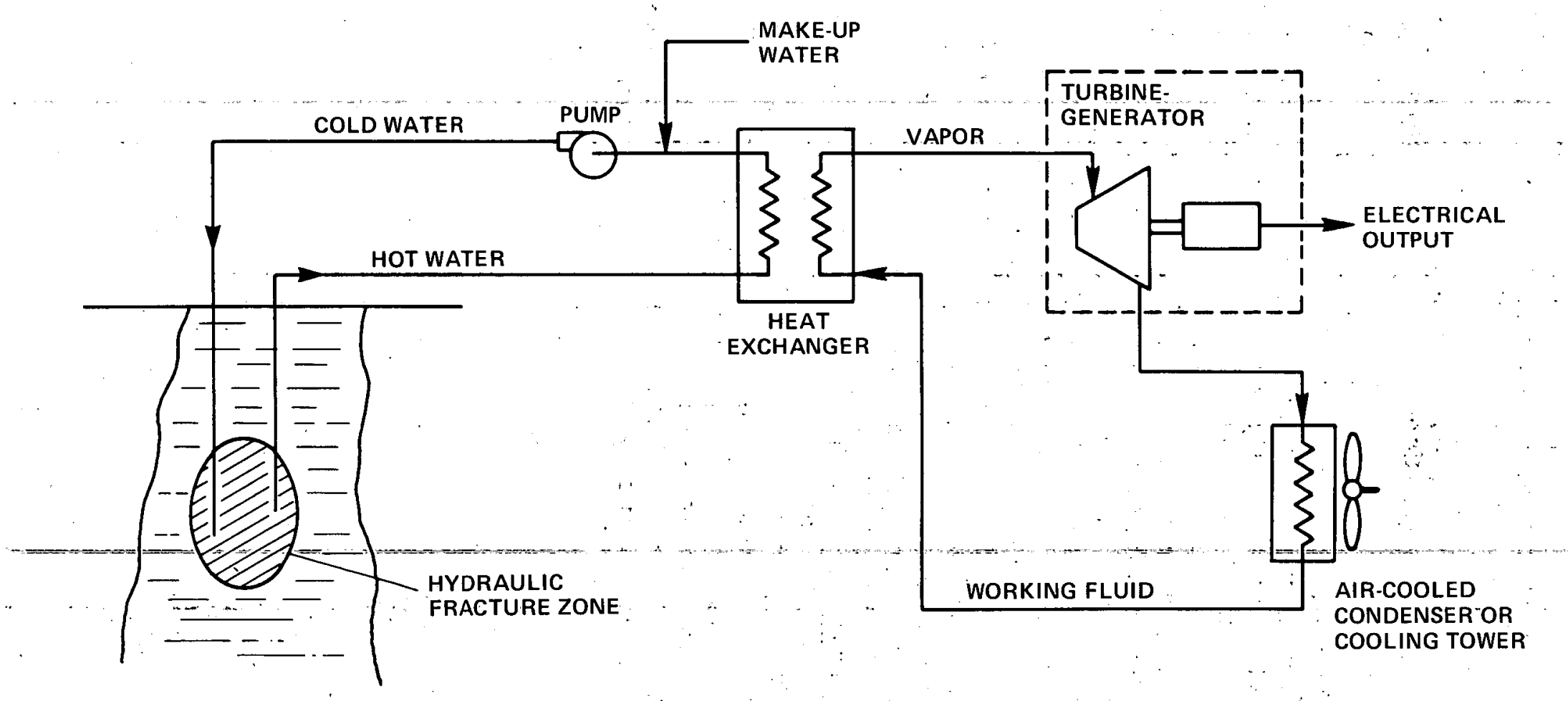

Figure 2-3. Electrical Power Generation From Hot Dry Rock Geothermal Resource 
The DOE geothermal environmental program consists of several elements:

- Environmental aspects of projects directly supportive of DOE geothermal resource and energy conversion technology development;

- Projects addressing generic environmental, health, and safety (EH\&S) issues, generally of longer term and more fundamental in ": nature, with applicability to geothermal as well as other technologies;

- Projects designed to support and enhance the geothermal resource development efforts. of other Federal agencies; and

- Projects designed to support promising regional or area geothermal resource development activities outside the Federal program.

These elements support DOE and other agency projects for development, demonstration, and commercialization of geothermal resources. Schedules and milestones of the geothermal technology development and demonstration program are presented in Figures 2-6 through 2-9.

\section{Geothermal Loan Guaranty Program}

In addition to the research, development, and demonstration of geothermal energy technologies as provided for by the Geothermal Energy Research, Development, and Demonstration Act of 1974 (P.L. 93-410), a loan guaranty program was provided for encouraging and assisting the financing of geothermal energy development. A summary of activities covered by the Geothermal Loan Guaranty Program is given in Table 2-1. 


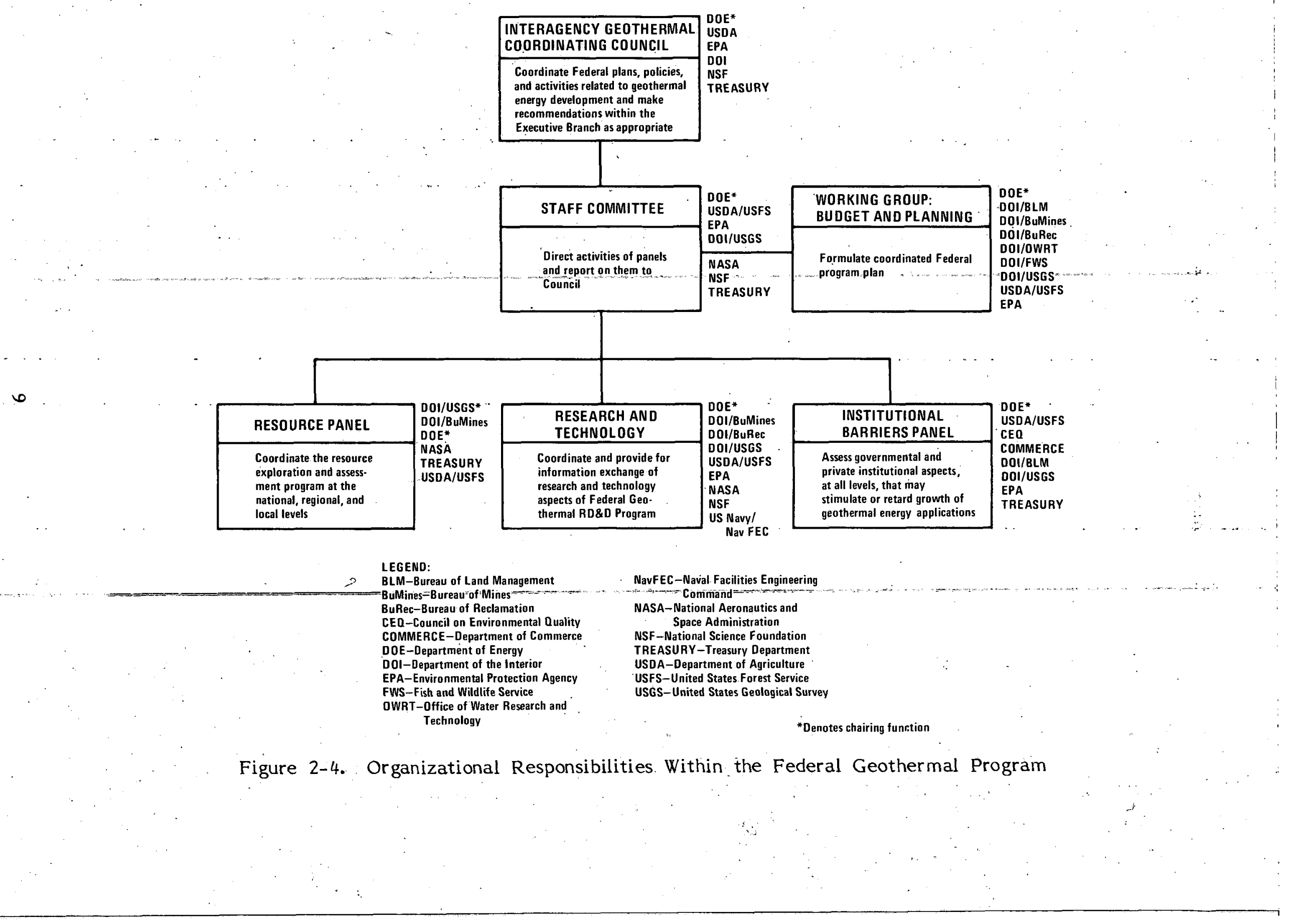




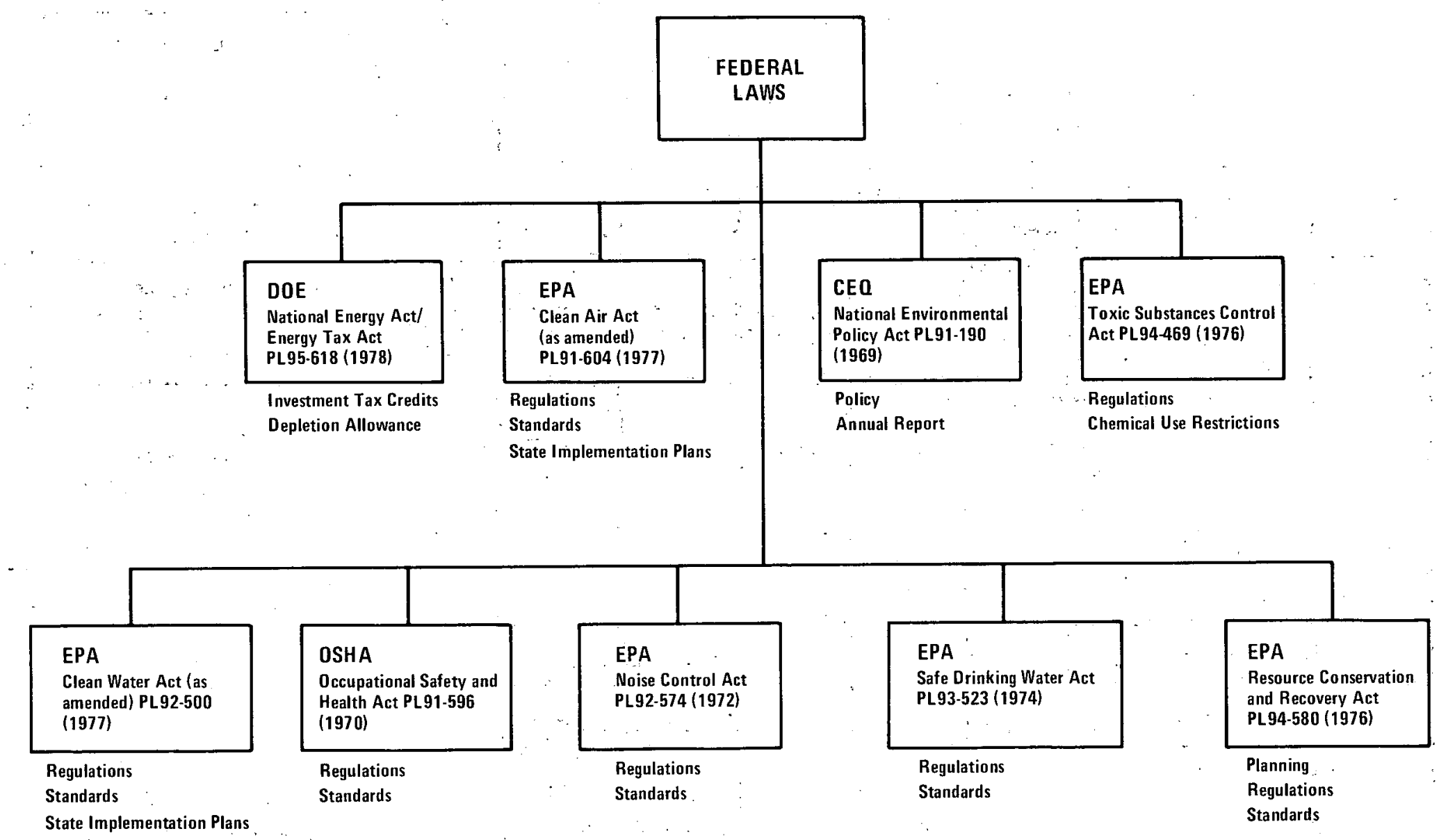

Figure 2-5. Federal Environmental Laws for Geothermal Energy Systems 


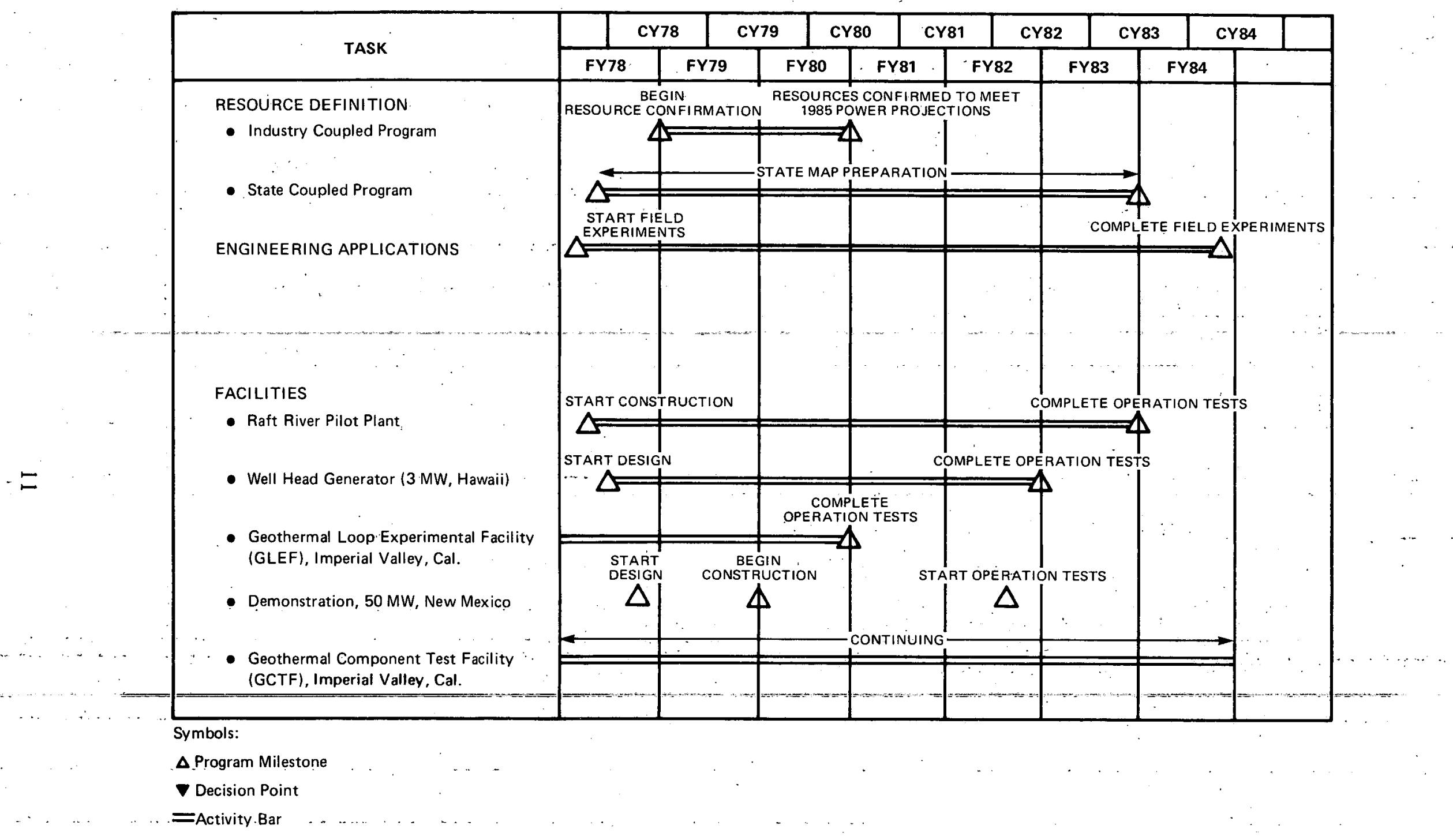

Figure 2-6. Milestones for Hydrothermal Systems 


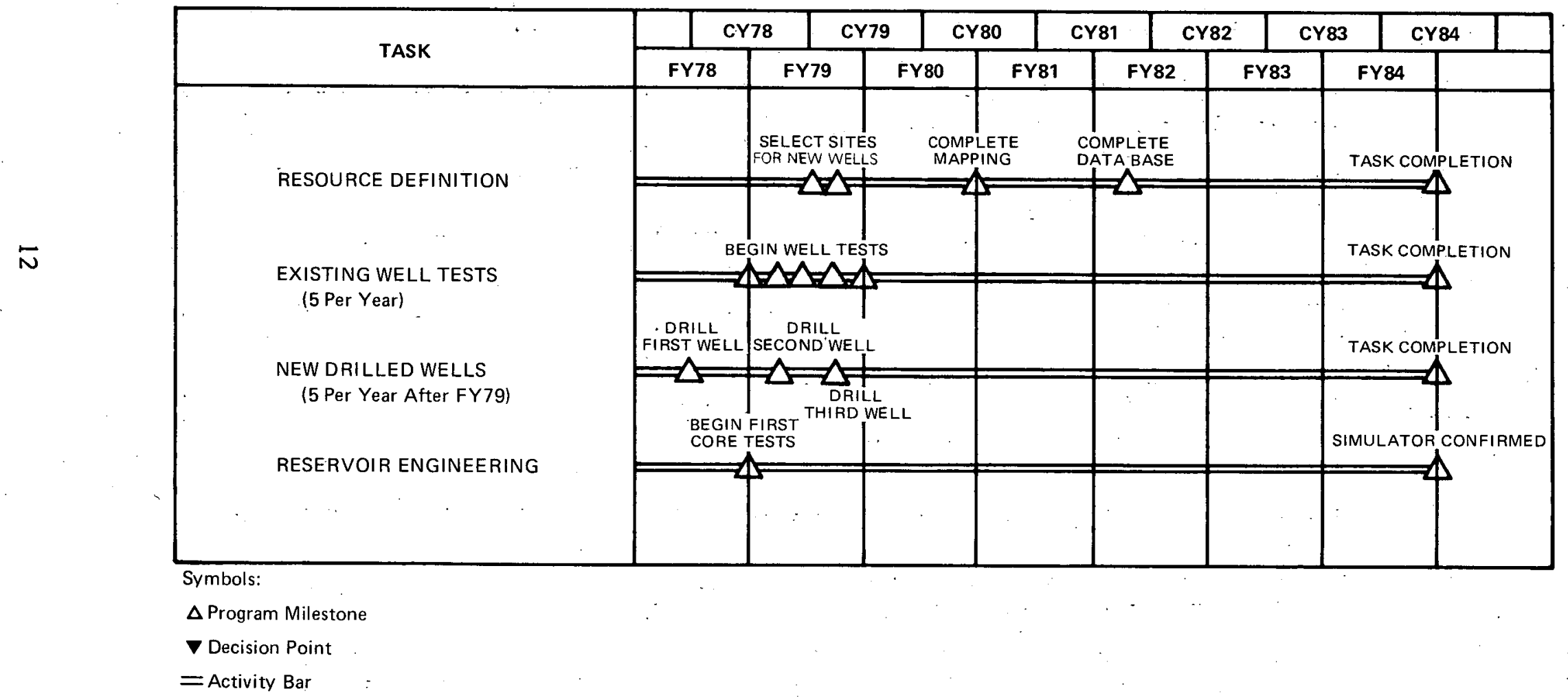

Figure 2-7. Milestones for Geopressured Systems 


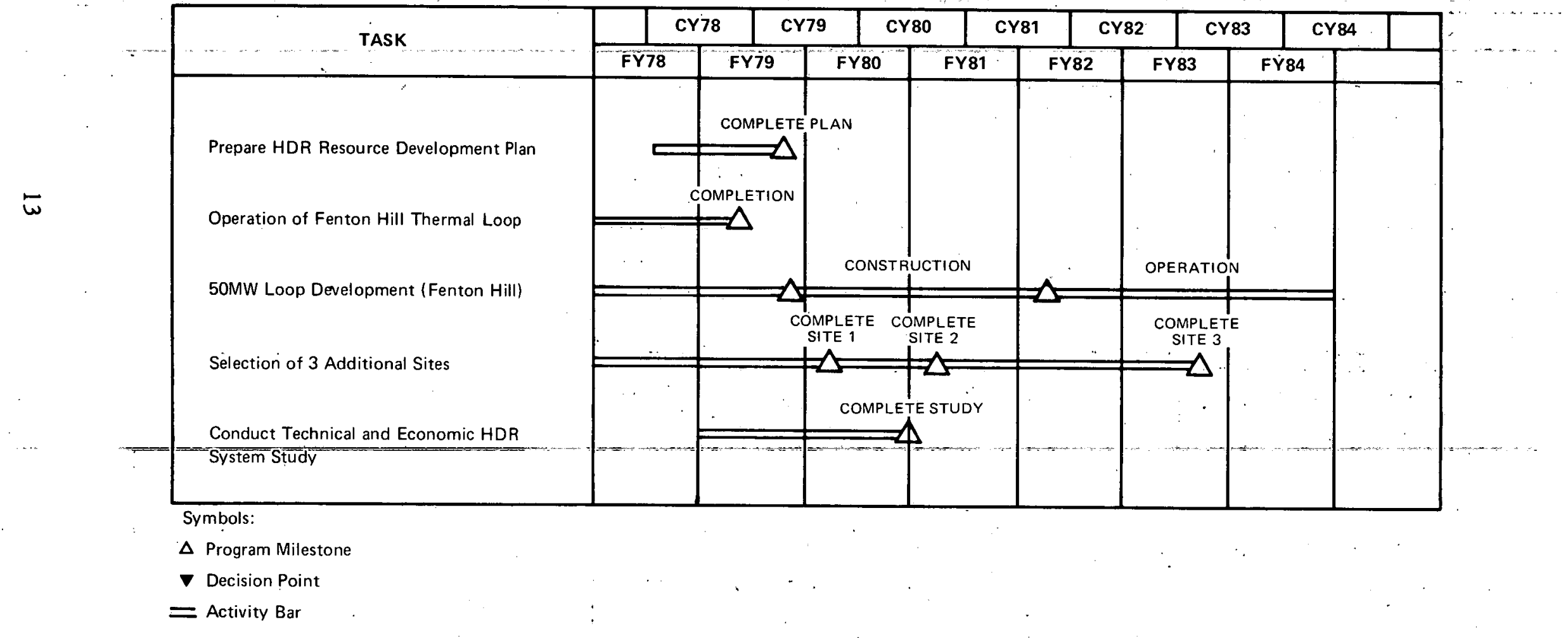

Figure 2-8. Milestones for Hot Dry Rock Systems 


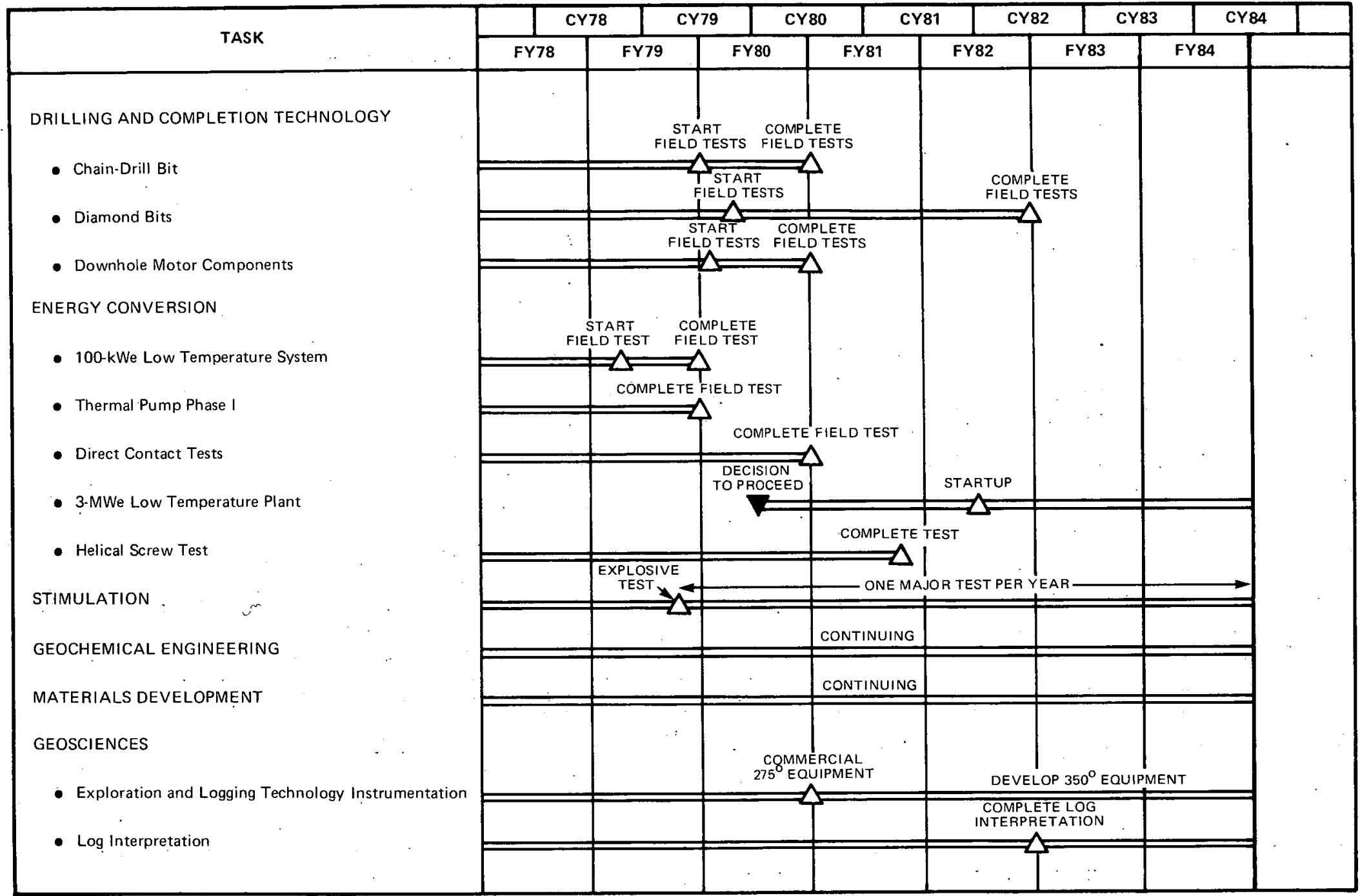

Symbols:

$\Delta$ Program Milestone

$\nabla$ Decision Point

$=$ Activity Bar

Figure 2-9. Geothermal Technology Development 


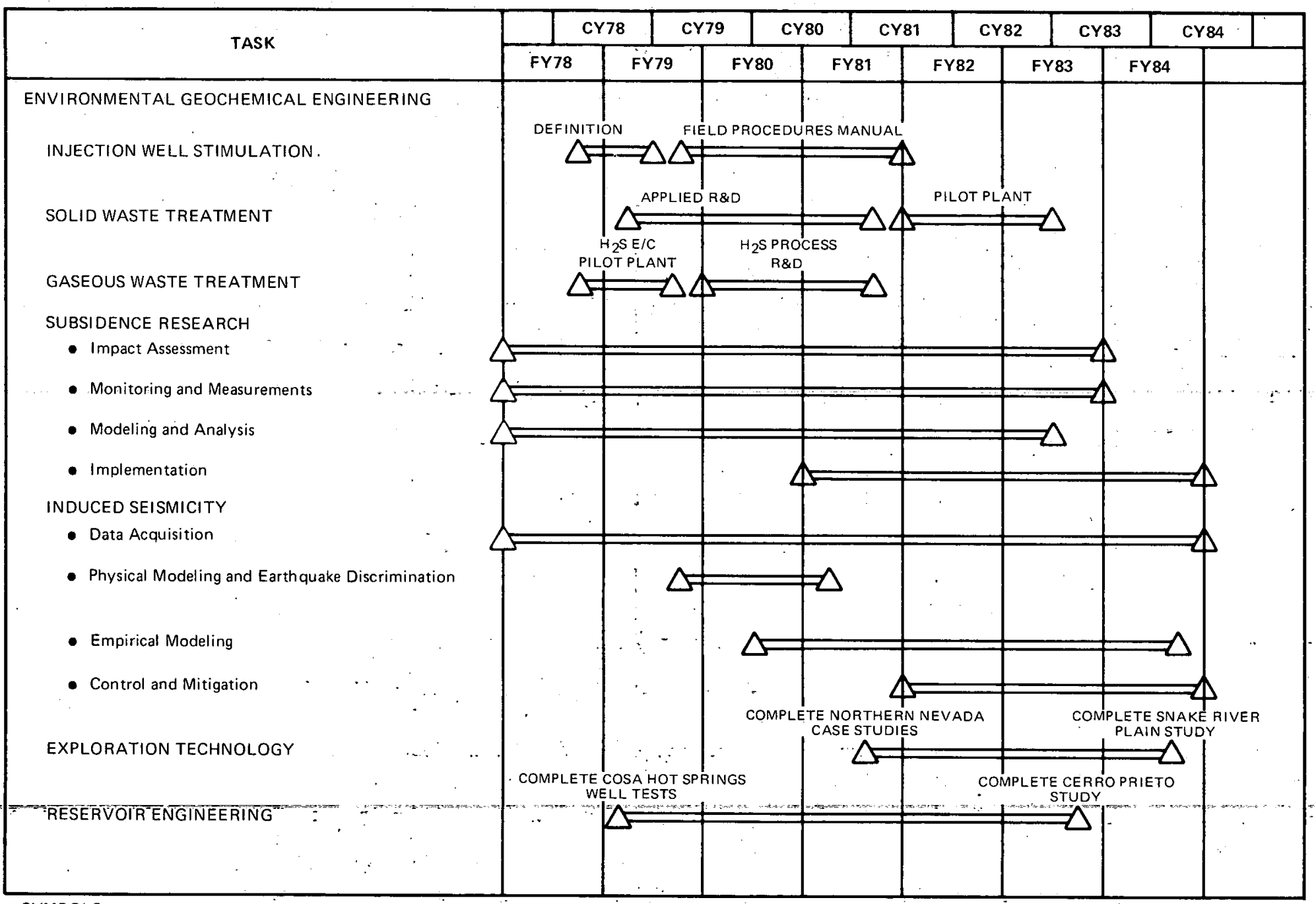

\section{SYMBOLS:}

$\triangle$ Program Milestone

$\checkmark$ Decision Point

= Activity Bar

Figure 2-9. Geothermal Technology Development (concluded) 
Table 2-1. Geothermà Loan Guaranty Program

(Applications List)

\begin{tabular}{|c|c|c|c|c|}
\hline $\begin{array}{l}\text { Approval Goal } \\
\text { or Status }\end{array}$ & Applicant & Project/Location & Goal & $\begin{array}{l}\text { Loan Guaranty } \\
\$ \text { millions }\end{array}$ \\
\hline FY 1978 & . & . & & \\
\hline $\begin{array}{l}\text { Environmenta] } \\
\text { assessment in } \\
\text { revision (drilling } \\
\text { site change) }\end{array}$ & $\begin{array}{l}\text { Republic Geothermal } \\
\text { Inc. and MAPCO }\end{array}$ & $\begin{array}{l}\text { Westmorland Development Project: } \\
\text { Explore, evaluate, and develop } \\
\text { field/Westmorland, Imperial } \\
\text { Valley, California }\end{array}$ & 55 MWe & $\begin{array}{l}21.0 \\
\text { (Bank of America) }\end{array}$ \\
\hline $\begin{array}{l}\text { To DOE Hq. } \\
\text { Sept. or Oct. }\end{array}$ & $\begin{array}{l}\text { Honey Lake } \\
\text { Hydropon ic Farms }\end{array}$ & $\begin{array}{l}\text { Honey Lake Farms Project: } \\
\text { Heat greenhouses and packing sheds, } \\
\text { refrigerate produce prior to } \\
\text { shipment/hendell-Amedee known } \\
\text { geothermal resource area (KGRA), } \\
\text { Susanville; California }\end{array}$ & (Nonelectric) & (Bank of Montreal) \\
\hline In Review & $\begin{array}{l}\text { 0'Brien Resources } \\
\text { Corp., Thermal Power } \\
\text { Inc., Amax Exploration, } \\
\text { Inc., and VTN Corp., Inc. }\end{array}$ & $\begin{array}{l}\text { O'Brien Project: Verify reservoir } \\
\text { and develop field/Roosevelt Hot } \\
\text { Springs KGRA, Beaver County, Utah... }\end{array}$ & 55 MiNe & $\begin{array}{l}12 \\
\text { (Bank of Montreal) }\end{array}$ \\
\hline FY 1977 & & & . & \\
\hline $\begin{array}{l}\text { Hold (added } \\
\text { preliminary } \\
\text { exploratory } \\
\text { drilling) }\end{array}$ & $\begin{array}{l}\text { Dry Creek Exploration, } \\
\text { Inc., (Subsidiary of } \\
\text { Geotherma] Resources } \\
\text { International) }\end{array}$ & $\begin{array}{l}\text { Dry Creek Prospect: Explore, } \\
\text { evaluate, and develop field/Lake } \\
\text { County (Geysers), California }\end{array}$ & 165 MWe & $\begin{array}{l}7.5 \\
\text { (Bank of America) }\end{array}$ \\
\hline Approved & Repub]ic Geothermal, Inc. & $\begin{array}{l}\text { E. Mesa Development Project: } \\
\text { Evaluate and develop field/ } \\
\text { E. Mesa, Imperial Valley, } \\
\text { California }\end{array}$ & 48 MWe & $\begin{array}{l}10.0 \\
\text { (Bank of America) }\end{array}$ \\
\hline$\cdot$ & $\cdot$ & 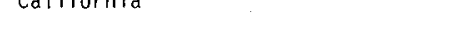 & & \\
\hline Approved & $\begin{array}{l}\text { McCul loch Geothermal } \\
\text { Corp. }\end{array}$ & $\begin{array}{l}\text { CU I Venture: } \\
\text { Explore and evaluate fields/ } \\
\text { Brawley, California }\end{array}$ & 110 MWe & $\begin{array}{l}6.3 \\
\text { (Bank of Montreal) }\end{array}$ \\
\hline Hold & $\begin{array}{l}\text { Southern California. } \\
\text { Public Energy Corp. } \\
\text { (City of Burbank) }\end{array}$ & $\begin{array}{l}\text { Site seiection appraisals/ } \\
\text { Roosevelt Hot Springs, Utan }\end{array}$ & $\begin{array}{l}50 \text { MWe } \\
\text { to } \\
200 \text { MWe }\end{array}$ & $\begin{array}{l}25.0 \\
(\text { Dean witter } \\
\text { and } C 0 .)\end{array}$ \\
\hline Approved & $\begin{array}{l}\text { Geothermal Food } \\
\text { Processors }\end{array}$ & $\begin{array}{l}\text { Food Dehydration: . Rehab. } \\
\text { existing wells; Design and } \\
\text { build dehydrator plant/ } \\
\text { Brady's Hot Springs, Churchill } \\
\text { County, Nevada }\end{array}$ & (Nonelectric) & $\begin{array}{l}3.5 \\
\text { (Nevada National } \\
\text { Bank) }\end{array}$ \\
\hline Hold & Diablo Exploration, Inc. & $\begin{array}{l}\text { Select site, explore, evaluate, } \\
\text { and develop field/Rio Grande } \\
\text { Rift Valley, New Mexcio }\end{array}$ & 50 MWe & $\begin{array}{l}21.8 \\
\text { (Kidder, Peabody, } \\
\text { Inc.) }\end{array}$ \\
\hline $\begin{array}{l}\text { Construction } \\
\text { permit denied }\end{array}$ & $\begin{array}{l}\text { Resource Funding Ltd. } \\
\text { ('Northern California } \\
\text { Power Assoc., a con- } \\
\text { sorti um of cities) }\end{array}$ & $\begin{array}{l}\text { Explore, evaluate, develop } \\
\text { field/Cob Valley, Lake County } \\
\text { (Geysers), California }\end{array}$ & 66 MWe & 14.5 \\
\hline
\end{tabular}




\section{II. ENVIRONMENTAL CONCERNS A'ND REQUIREMENTS}

\section{A. INTRODUCTION}

Environmental changes have been observed to accompany development of hydrothermal resources in various parts of the world. The magnitudes of the associated EH\&S impacts have varied widely and depend upon the site, the character of the resource, the nature of the utilization system or process, and the success of control or mitigation efforts. This experience with hydrothermal systems provides a rational means of defining potential problems that must be resolved before significant additional development of hydrothermal systems, occurs. Priorities have not been set for these con-: cerns, however, because the ir relative importance is so dependent upon the resource characteristics (noncondensable gas content, total dissolved solids, etc.) and the nature of the regional setting (land use, socioeconomic structure, water availability, etc.). Thus, while the emission of hydrogen sulfide. is the most important issue at The Geysers geothermal resource area, the potential for land subsidence and water use conflicts are more significant issues in the Imperial Valley.

For geopressured and hot dry rock systems, there is no experience with fully developed systems, and the initial feasibility experiments are not yet completed. Therefore, it is possible at this time to predict the EH\&S concerns and requirements in only a general way. Appendix A briefly discusses" factors which, when considered in conjunction with site-specific screening criteria, constitute a reasonable and methodical technique for defining, setting priorities for, and scheduling the environmental research required to resolve environmental concerns. This technique will be applied as more experience with geothermal energy systems permits.

Important outputs of the DOE EH\&S program include recommendations concerning the degree of control that should be maintained over effluents and other undesirable impacts associated with the development of geothermal resources. These recommendations will be in the form of DOE environmental policy and design criteria and may subsequently provide the basis for regulätory actions by other agencies.

\section{B. ANALYSIS OF CONCERNS AND RESEARCH REQUIREMENTS \\ Concerns related to geothermal energy production were developed by} including all conceivable EH\&S problems within a general framework related to emissions, physical changes, land and water use conflicts, socioeconomic issues, and system safety. Research requirements were then generally developed for each concern so that the following factors were included where appropriate:

- Identify and measure (such as rates of release)

- Determine effects (e.g., dose-response curves) 
Assess the impacts of effects

Develop mitigation measures -where needed

Establish baseline and monitoring networks

Assess the impact of accidents

Emissions associated with vapor- and liquid-dominated geothermal resource applications are well defined for current technology. Most of the available data are from experience with electrical powerplants located at The Geysers area in Northern California. Additional information on residuals is related to precommercial operation of geothermal facilities in the Imperial Valley. Tables 3-1 and 3-2 list typical hydrothermal powerplant resource requirements and production residuals and chemical discharges, respectively. Because advanced $\mathrm{H}_{2} \mathrm{~S}$ abatement systems are still either in laboratory development or small pilot demonstrations, unabated values are given as a worst case. Values for residuals from geopressured applications are not given because actual operating experience is lacking.

\section{HYDROTHERMAL SYSTEMS: CONCERNS, REQUIREMENTS, AND STATUS}

As a result of recent analysis, the concerns listed in Table 3-3 have been generated for hydrothermal energy systems. In terms of timing and immediate impact on online power, the release of airborne effluents is the dominating concern. The continued operation and expansion of The Geysers is clearly dependent upon the ressolution of this concern through the application of control technology. In other areas, more importance must be assigned to ișsues such as land subsidence and cooling system water availability. Cultural issues may even be the dominating concerns for development at Coso Hot Springs, California, and in Hawaii.

\section{Release of Airborne Effluents}

The fluids in hydrothermal reservoirs contain varying amounts of chemical species that do not condense during the heat extraction process. The fractional content of such noncondensed gases varies widely, from 0.4 percent by weight at. The Geysers, California, to 30 percent at 'Monte Amiata, Italy. The major constitutent of this fraction is typically $\mathrm{CO}_{2}$, with lesser amounts of $\mathrm{NH}_{3}, \mathrm{H}_{2} \mathrm{~S}$, and $\mathrm{CH}_{4}$ and with trace amounts of $\mathrm{Rn}$, $\mathrm{Hg}, \mathrm{B}$, and other compounds. Most extraction and utilization techniques will result in the "release of these chemicals to the atmosphere unless control devices are used. An exception would be the use of a down-hole pump to maintain pressure on the fluid through a heat exchanger and an injection well. In theory, a closed loop could be maintained. Such down-hole pumps are now used in Iceland and are undergoing tests in Imperial Valley, California.

The calculated unabated emission, rates of these compounds at The Geysers are presented in Table 3-2. The collection of similar data for other reservoirs is a continuing requirement as development proceeds. 
Table 3-1. Hydrothermal Powerplant Resource Requirements and Production Residualsa

1. Powerplant size
a. Capacity
. Operation factor

c. Average power level

2. Land area per powerplant for geothermal facilities

3. Well field area per powerplant

4. Average downhole resource temperature

5. Geothermal fluid required

6. Geothermal fluid residual
a. Flashed steam system
b. Binary flow system
$21-45 \mathrm{~kg} / \mathrm{kWh}$
$30-60 \mathrm{~kg} / \mathrm{kWi}$

7. Steam condensate

0.03 sq. mi.

$.25-2.50 \mathrm{sq} . \mathrm{mi}$

$30-60 \mathrm{~kg} / \mathrm{kWh}$
Table 3-2. Measured or Calculated Unabated Discharge Rate of Several Chemicals to the Atmosphere at-The Geysers Powerplant, as a Result of Producing 502 MWe of Power
a. Flashed steam system

b. Binary flow system

8. Cooling water requi rements

9. Hydrocien sulfide emissions to the atmosphere
a. Flashed steam system
$1.2-2.4 \mathrm{~g} / \mathrm{kWh}$

10. Thermal efficiency

$10-12 \%$

\section{$-15 \mathrm{~kg} / \mathrm{kWh}$}

$60-90 \frac{\mathrm{acre}-\mathrm{ft}}{\mathrm{MW}-\mathrm{yr}}$

D.L. Ermak, "A Scenario for Geothermal Electric Power

Development in Imperial Valley," Energy, Vol. 3, 203

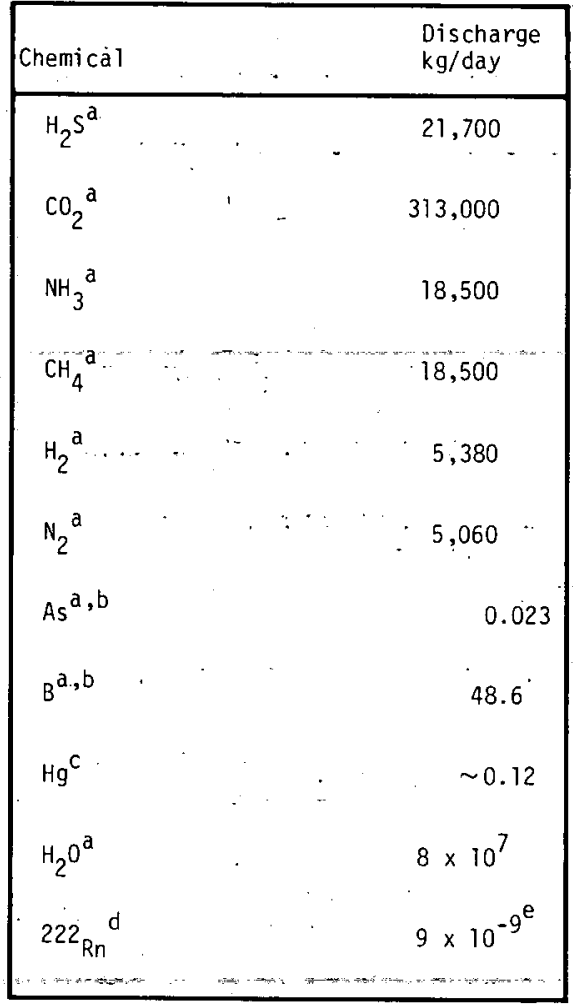

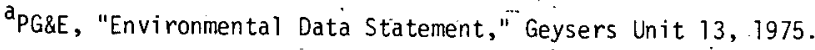

based on calculated cooling tower drift rates.

$\dot{c}_{D . E}$. Robertson, Battelle, Pacific Northwest Laboratories, personal communication, 1978.

${ }_{\text {L.R. Anspaugh, Lawrence Livermore Laboratory, } 1978 .}$

$e_{9} \times 10^{-9} \mathrm{~kg}=1.4 \mathrm{Ci}$ 
Table 3-3. Environmental, Health, and Safety Concerns and Requirements for Hydrothermal Energy Systems

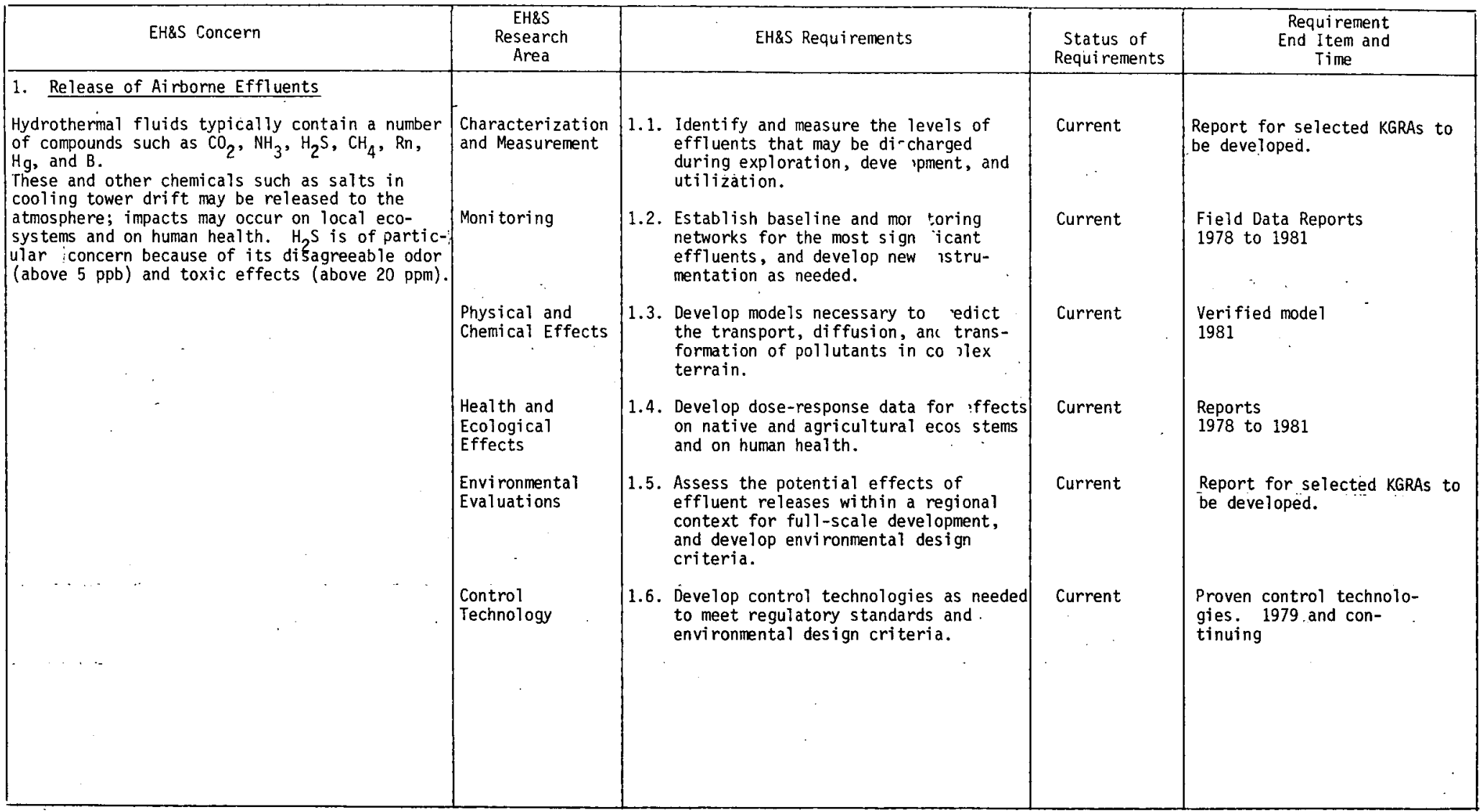


Table 3-3. Environmental, Health, and Safety Concerns and

Requirements for Hydrothermal Energy Systems (Continued)

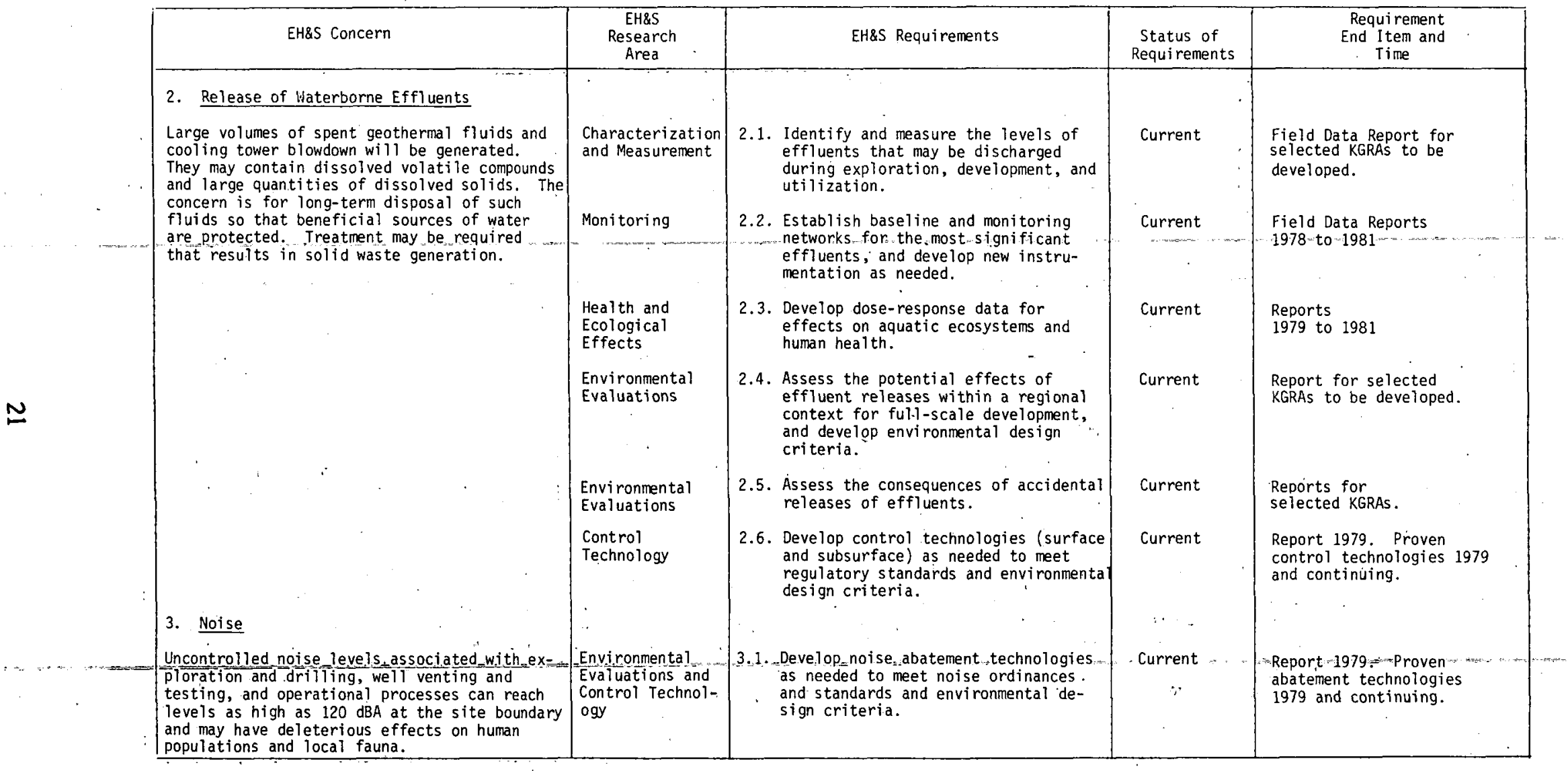


Table 3-3. Environmental, Health; and Safety Concerns and Requirements for Hydrothermal Energy Systems (Continued)

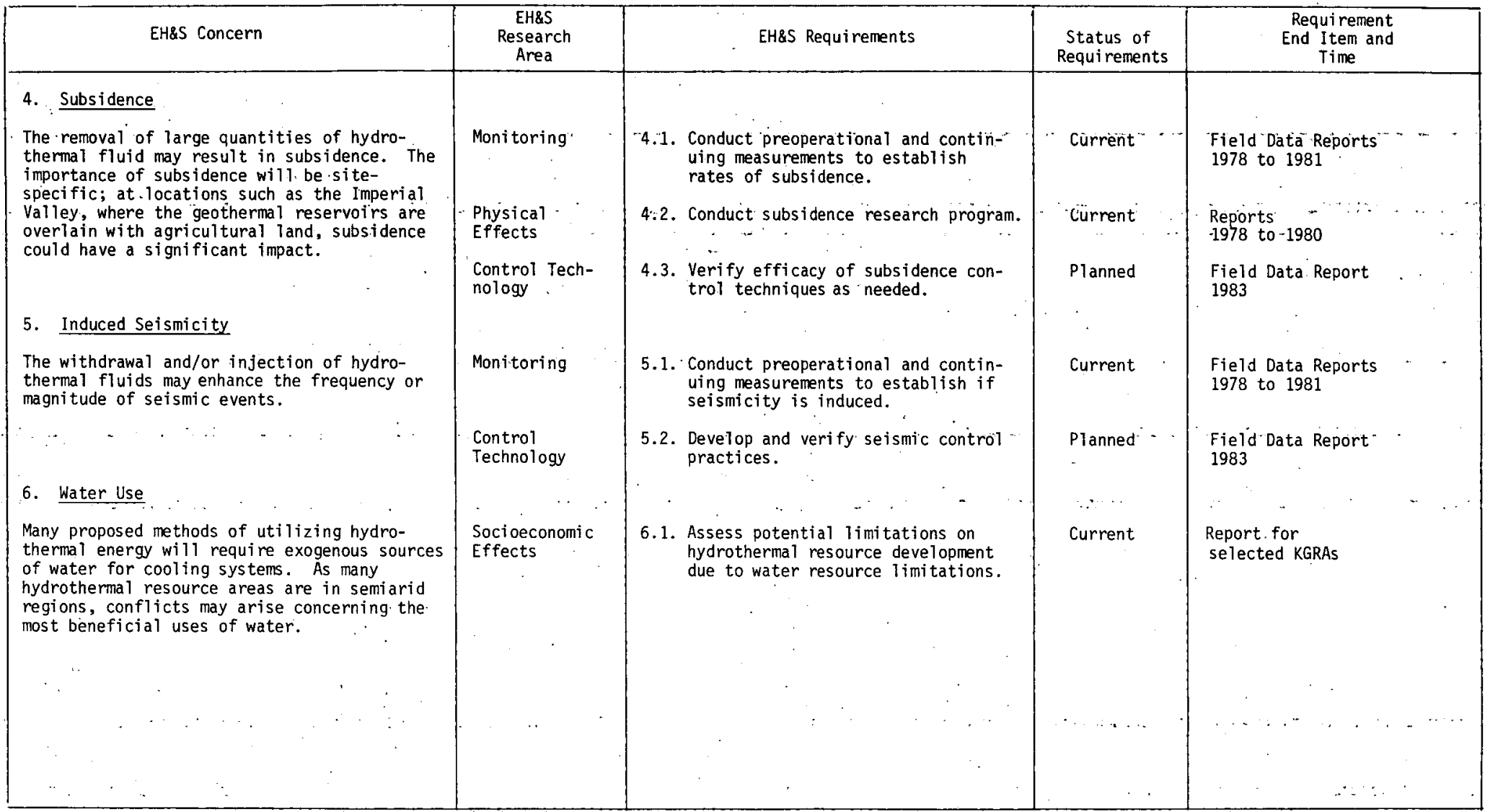


Table 3-3. Environmental, Health, and Safety Concerns and Requirements for Hydrothermal Energy Systems (Continued)

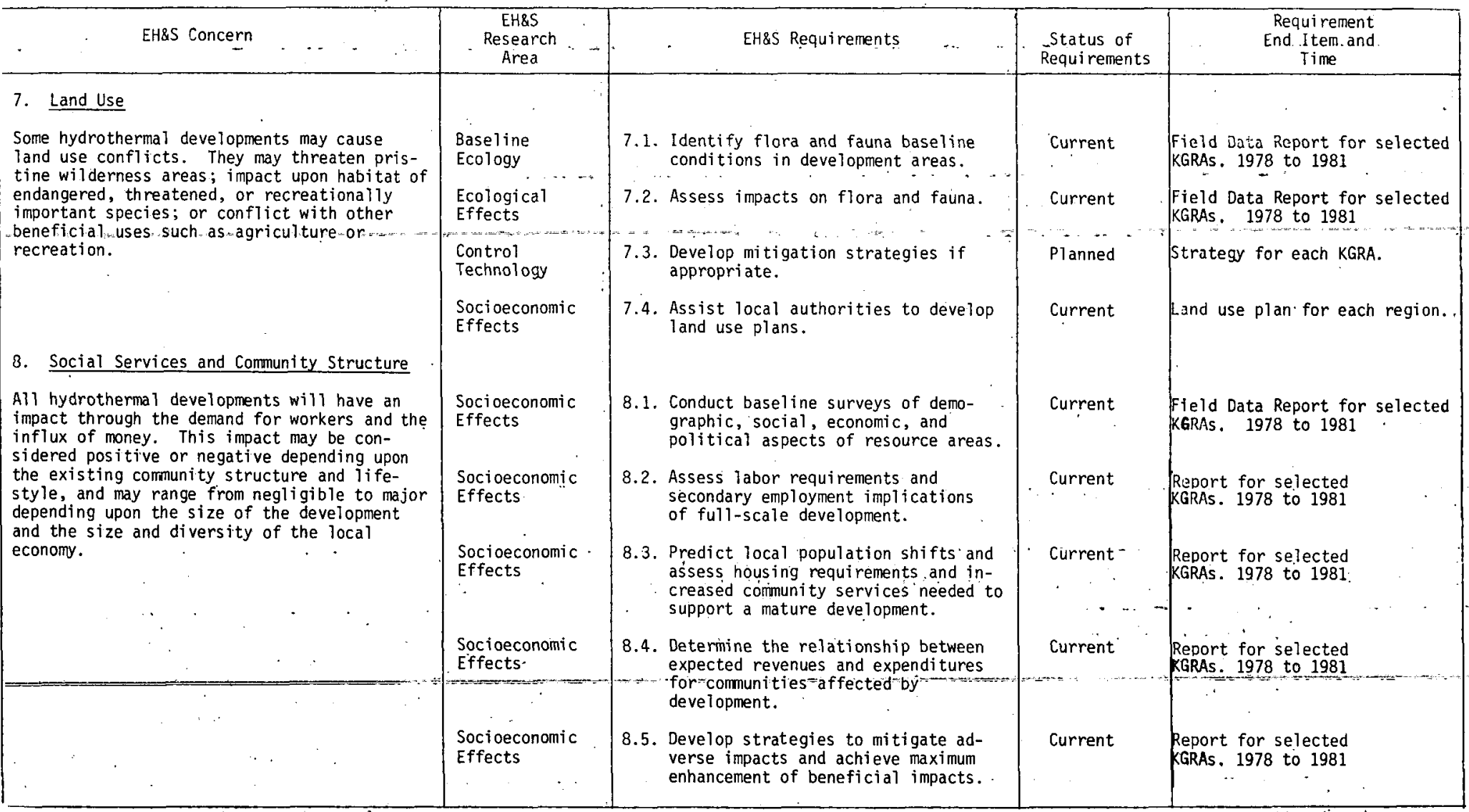


Table 3-3. Environmental, Health, and Safety Concerns and

Requirements for Hydrothermal Energy Systems (Continued)

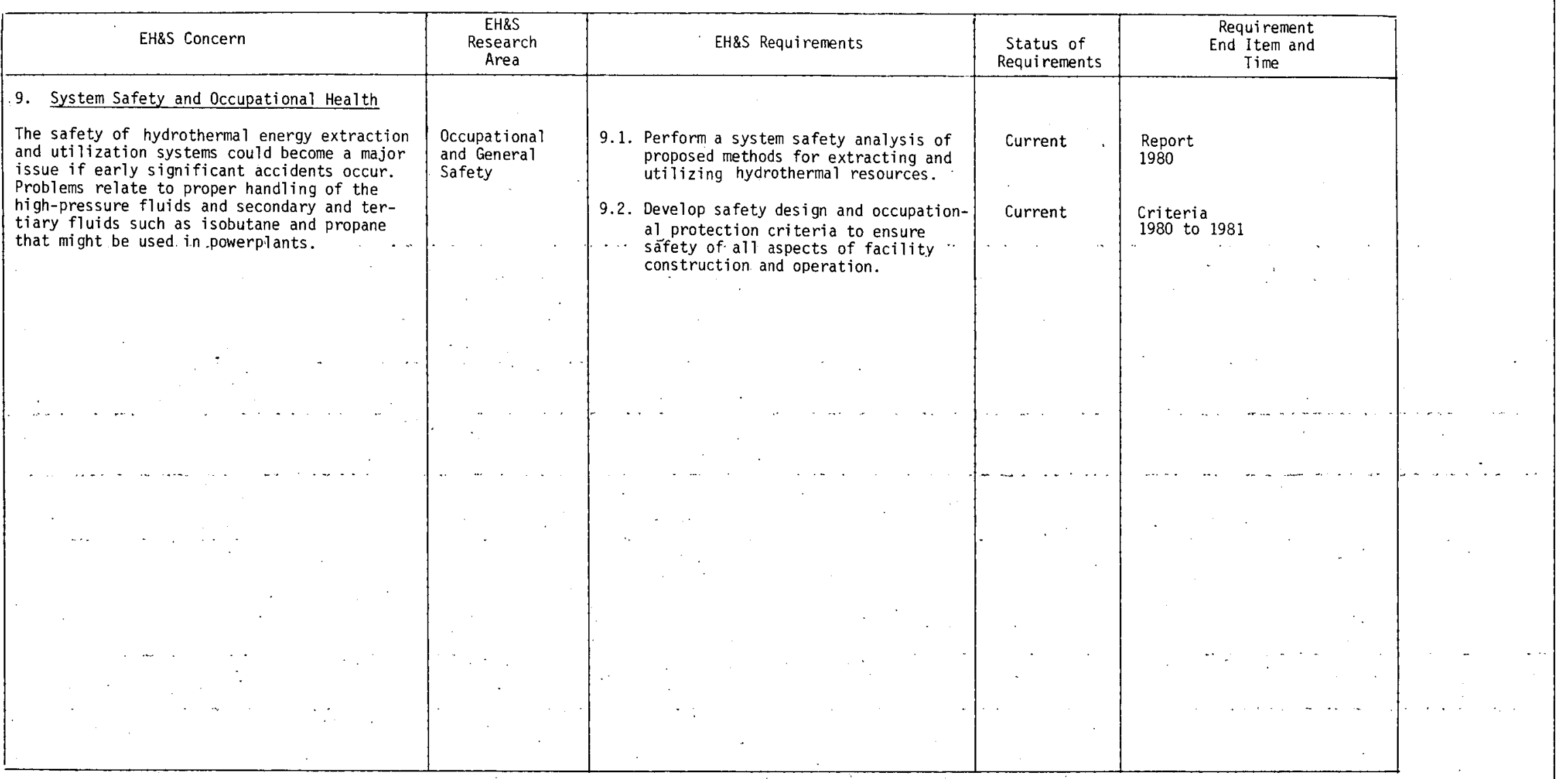


The release of $\mathrm{CO}_{2}$ by hydrothermal powerplants is significant only in a global context, and it is extremely unlikely that hydrothermal powerplants will make a significant contribution to the total flux of $\mathrm{CO}_{2}$ to the atmosphere.

The release of $\mathrm{H}_{2} \mathrm{~S}$ is a substantial problem at The Geysers and has resulted in adverse reactions from the downwind communities. The odor detection threshold of humans for $\mathrm{H}_{2} \mathrm{~S}$ is about $0.005 \mathrm{ppm}$ (by volume), and the California standard for ambient air is $0.030 \mathrm{ppm}$. . The California standard is sometimes exceeded, and regulatory agencies have required the operator to develop a pollution abatement program as a condition for the expansion of the power production facilities. Health effects from exposure to $\mathrm{H}_{2} \mathrm{~S}$ at these low levels have not been unequivocally demonstrated but have been claimed by residents in The Geysers area. 'Effects of $\mathrm{H}_{2} \mathrm{~S}$ ' on vegetation have been demonstrated at concentrations in air of several parts per million. The presently available evidence indicates that vegetation damage from this mechanism will not occur due to hydrothermal operations, but more research is needed to confirm this with additional vegetation species and to examine the synergistic action of $\mathrm{H}_{2} \mathrm{~S}$ with other pollutants such as $\mathrm{O}_{3}$. In the atmosphere, $\mathrm{H}_{2} \mathrm{~S}$ is slowly oxidized to $\mathrm{SO}_{2}$ and $\mathrm{SO}_{4}=$. The formation of sulfate and other sulfur-containing particulates is therefore certain. However, the slow conversion rate of $\mathrm{H}_{2} \mathrm{~S}$ to other sulfur compounds indicates that this will probably not present an actual problem because considerable dispersion will have occurred while conversion is taking place. In actuality, it is very unlikely that any new, commercial-scale hydrothermal powerplant will be built in the United States without either $\mathrm{H}_{2} \mathrm{~S}$ abatement mechanisms or demonstrable proof that they are unnecessary due to the nature of the reservoir.

Present power units at The Geysers use direct-contact condensers. Because $\mathrm{H}_{2} \mathrm{~S}$ is soluble in water, about 70 percent of the $\mathrm{H}_{2} \mathrm{~S}$ is carried to the cooling tower with the condensate. Present environmental control technology consists of ducting the ejector off-gas to the cooling tower and adding an iron catalyst to the cooling water to oxidize $\mathrm{H}_{2} \mathrm{~S}$ to elemental sulfur. This method is not highly successful because of limited abatement, increased maintenance costs, and the need to dispose of large volumes of cooling tower sludge that contains unusable sulfur. New power units at: The Geysers will have indirect contact condensers that will result in about 90 percent of the $\mathrm{H}_{2} \mathrm{~S}$ going to the off-gas ejector stream. This $\mathrm{H}_{2} \mathrm{~S}$ will then be oxidized to commercial quality sulfur by the Stretford process. The first unit of this design should be online in FY 1979 and may achieve 90-percent abatement while the units are in operation. However, this system cannot be retrofitted economically to the older units and will not have any effect when it is necessary to vent steam directly to the atmosphere. The required solution is an upstream scrubber that can remove $\mathrm{H}_{2} \mathrm{~S}$ from steam before it reaches the turbine. Such a scrubber is under development by DOE and others and will undergo 1/20-scale tests in FY 1979.

Substantial amounts of $\mathrm{NH}_{3}$ are also released at The Geysers. Measurements indicate that emission rates of $\mathrm{NH}_{3}$ are lower at other hydrothermal sites. The significance of ammonia release appears to be minor. 
Ammonia is frequently used as a plant fertilizer and is probably nontoxic to vegetation and mammals at expected concentrations. Dissolved ammonia is toxic to aquatic life, but airborne releases of ammonia should not be significant. There may be complex interactions of ammonia, sulfur compounds, and particulates that produce potentially harmful pollutants. This possibility deserves further analysis, but it is not presently considered to be an important issue.

Although not presumed to be a reaction to $\mathrm{H}_{2} \mathrm{~S}$, vegetation stress has occurred at The Geysers in the immediate area of the power-generating units. Presently available evidence indicates that this stress may be due to boron. This is a minor problem at The Geysers but could be of more importance at other reservoirs or with other adjacent land uses. More data are needed on the presence of boron in hydrothermal fluids.

Mercury emission rates have recently been reported for The Geysers and Cerro Prieto, Mexico. The airborne release rates are small, 90 micrograms per kilowatt-hour $(\mathrm{g} / \mathrm{kWh})$ and 30 to $70 \mathrm{~g} / \mathrm{kWh}$ at three measured units at The Geysers. These releases appear to be inconsequential. Ambient air at The Geysers has the same concentration of mercury as was measured at background locations, although ambient air at Cerro Prieto was above background levels. Additional measurements at other sites are needed to resolve this issue for local conditions.

The release of radon-222 and other radionuclides has also recently been measured at The Geysers. The average emission rate of radon-222 is 130 nanocuries $/ \mathrm{kWh}$. Concentrations in ambient air of the short-lived radondaughters at The Geysers are within the range of concentrations measured at background locations. Levels of other naturally occurring radionuclides in The Geysers area were also within normal background levels. Measurements of radon in fluids at other sites also indicate that the release of radionuclides at hydrothermal sites will not be an important issue. However, confirmatory measurements of emission rates and ambient concentrations in the vicinity of new uses, particularly nonelectric applications, will be necessary.

More detailed source-term measurements at sites of hydrothermal use are needed to determine the levels of some toxic trace constituents which may be released. In particular, information on compounds such as hydrogen fluoride, mercaptans, and volatile hydrides is needed. These compounds very likely exist in hydrothermal fluids, but very few measurements are now available.

Airborne effluents in the form of cooling system drift are also expected at all hydrothermal powerplants. The magnitude of this potential problem is very dependent upon technological options. In the Imperial Valley, for example, commercial powerplants will very likely be forced to maintain fairly high salinity levels in their cooling systems because high quality water is not expected to be available. If steam condensate is used as cooling water makeup, then the concentration of many ionic species in the cooling 
system will be altered. Expected emissions will be in the form of particles composed of common salts and many trace contaminants including boron and cooling system additives. Cooling system drift may therefore stress surrounding vegetation. Studies and assessments of this problem are planned.

By far the largest of the airborne emissions from geothermal powerplants will be water vapor. Because the thermodynamic efficiency of such powerplants is low, the release rate per unit energy produced is higher than for other conventional power plants. In some locations, this water vapor release may result in local fogging and icing conditions.

\section{Release of Waterborne Effluents}

The management of spent hydrothermal fluids is one of the most important issues confronting development at many locations, although some hydrothermal fluids are so pure they have been used for irrigation and other beneficial uses. Some fluids in Imperial Valley, however, are very saline, and discharges to surface waters would not be desirable or permitted. The anticipated disposal scheme is to inject the spent fluids back into the geothermal reservoir. Injection of excess steam condensate has been carried out successfully for several years at The Geysers. Prior to injection, the excess condensate had been released into surface waters, but this was found to be detrimental to aquatic life, probably due to the dissolved ammonia.

Long-term injection tests are currently being conducted in the Imperial Valley with spent fluids of greater salinity. These tests appear to be successful although there are still serious concerns of scaling and well-bore plugging due to precipitation of silica. Preliminary results from hightemperature (above $145^{\circ} \mathrm{C}$ ) injection of geothermal fluids have been encouraging. It may be realistic, therefore, to assume that hydrothermal powerplants utilizing many liquid-dominated reservoirs can be operated over long periods with no intentional release of spent hydrothermal fluids to surface waters or into underground aquifers of beneficial use. Research studies and long-term monitoring at selected sites are necessary, however, to ensure that unintentional contaminations do not occur. The accidental release of geothermal fluids could, in some areas, have a serious impact on aquatic and tẹrestrial ecosystems.

Some of the very saline fluids, constituting less than 5 percent of the U.S. hydrothermal resources, such as those in the Salton Sea known geothermal resource area (KGRA), cannot be injected directly back into the reservoir due to scaling, precipitation, and plugging problems and very high attendant maintenance costs. Treatment of the spent fluids will therefore be required prior to injection, leading to a need to dispose of large volumes of sludge in waste disposal sites and accompanying concerns of adequate disposal site selection and maintenance to avoid contamination of surface water and groundwater.

There are also problems with waterborne effluents during the welldrilling process. These problems are not unique to geothermal energy, but 
contaminating events have occurred on several occasions at geothermal sites. These releases are of an accidental nature and are already covered by regulations. It is hoped that improved procedures will eliminate or greatly reduce such releases in the future.

Another potentially major issue involving waterborne effluents concerns heat rejection systems. There are many options for the design of such systems, but the options may be severely limited by available water quantity and quality and by cost. Most practical cooling systems will probably require the discharge of cooling water blowdown. This water will be brackish and may contain additives or geothermal fluid carryover if steam condensate is used as makeup water. For hydrothermal systems, it may be possible to inject this blowdown with the spent hydrothermal fluids, but there are serious questions whether the two fluids can be mixed without worsening the scaling problem in some liquid-dominated systems. The cooling system design of any proposed hydrothermal use must be evaluated carefully for possible effects on aquatic ecosystems, both by the dissolved. solids and by the thermal discharge.

\section{Noise}

Noise" has been a significant problem at The Geysers, with resulting complaints from nearby residents. Major noise-producing events are the venting during well completion and the discharge of mainline steam to the atmosphere when power-producing units are shut down. (This venting has been allowed to continue if the power unit is down for only a short period. The reopening of shut-in wells can dislodge damaging debris.) : This problem has been reduced by the use of better mufflers and the installation of crossties between steamlines so that it is not necessary to release as much steam to the atmosphere when power units are shut down. Studies of the impact of noise on wildlife at The Geysers have been completed; results indicate that there is no discernible impact. There is a need, however, for portable mufflers to reduce noise levels when wells must be vented. A state-of-theart study of this problem is planned.

The noise issue is expected to be much less important at liquiddominated hydrothermal sites. Steam pressures are lower, and noise levels associated with well tests are much lower than at The Geysers. Measurement programs will be necessary, however, and mitigation measures will be employed if necessary.

\section{Subsidence}

The removal of large quantities of fluid. from a geologic formation may result in subsidence, or sinking of the land. Such subsidence has been common following the withdrawal of water and oil. It has also been observed at the Wairakei, New Zealand, hydrothermal powerplant where a maximum rate of subsidence of about 1.3 feet/year has been measured. However, the injection of spent geothermal fluids back into the formation is not done at Wairakei; the spent fluids are discharged into surface waters. 
It is hoped that the injection of spent hydrothermal fluids back into the reservoir will not only solve the liquid waste problem but will also eliminate or mitigate the subsidence problem. However, this is not known with certainty; localized sinking around withdrawal wells and uplifting around injection wells may occur.

A better understanding of geothermal reservoirs and the factors that control subsidence may eventually lead to the development of management strategies that can completely control subsidence. This is an area of active research and, in 1977; DOE established a subsidence research project at Lawrence Berkeley Laboratory. It is necessary to assess the problem by acquiring precise leveling data to measure actual rates of subsidence at geothermal facilities. Baseline data are also important because many geothermal sites can be expected to be undergoing tectonic subsidence. A naturally occurring subsidence of 13 centimeters was observed in the northern end of Imperial Valley during a recent 2-year period.

The importance of subsidence will be site specific. It may be of significant importance at locations such as the Imperiâl Valley where the geothermal reservoirs are overlain by agricultural systems using gravity-flow irrigation and drainage systems. Subsidence in naturally hilly locations may cause only minor or insignificant problems.

\section{Induced Seismicity}

Many hydrothermal reservoirs are located in regions with a high frequency of naturally occurring seismic events. A significant issue is whether the withdrawal and injection of geothermal fluids may enhance the rate of microseismic events, or even trigger a major earth movement. Although one study implicates the process of reservoir cooling, the most likely cause of induced seismicity is believed to be the injection process. Studies in Colorado have demonstrated that the frequency of microseismic events is increased as a result of the high-pressure injection of fluids.

It is not known what pressures will be required to maintain the injection of spent hydrothermal fluids over long periods of time at liquiddominated sites, but field trials indicate that the pressures may be well below those demonstrated to cause induced microseismicity. The possible lubrication of a major fault and the resultant triggering of a major earthquake is another unresolved issue; careful site selection to avoid major faults should alleviate this concern.

Because these potential effects are unresolved, detailed microseismic studies must be conducted at geothermal sites. Balseline data on the frequency of seismic events and the depth at which they occur will provide valuable information in distinguishing between naturally occurring and induced events. In the Imperial Valley, for example, the depth of occurrence of nearly all naturally occurring seismic events is far below the depth of the 
hydrothermal reservoirs. Any sudden shift in the depth of earthquake foci to the depth of the reservoir would be strong evidence that geothermal production had, in fact, induced seismicity.

In 1979, DOE established a new program to study induced seismicity. The program, which will be managed by the Nevada Operations Office, seeks ultimately to recommend guidelines for assessing the risk of inducing seismic events during geothermal development and production. The program will utilize existing and new data to evaluate the usefulness of prediction models.

\section{Water Use}

Nearly all proposed methods of utilizing hydrothermal reservoirs for the production of electricity will require exogenous sources of water for heat rejection systems. As most reservoirs are in the semiarid regions of the West, conflicts over the allocation of limited water resources are expected. Such a conflict has already arisen in the Imperial Valley where the agricultural community is limited by the availability of water imported from the Colorado River. Research is in progress to assess this problem fully and to suggest measures to resolve, this conflict through a series of tradeoffs. Similar studies in other. KGRAs are needed.

\section{Land Use}

Any human activity, including the exploration for and the development of geothermal reservoirs, can put pressure upon native flora and fauna. Because geothermal energy is extracted as heat, it cannot be transported over long distances but must be utilized close to the location where it is found. This may result in conflicts over land use. Such issues will be extemely site specific. The most significant issues are expected to arise when goethermal reservoirs are located on or adjacent to areas designated or nominated as critical habitat areas under the Endangered Species Act. Such issues may be expected not only at sites of exploration and energy extraction, but for powerline corridors as well.

It is therefore essential that information concerning the presence of endangered and threatened species be obtained prior to development. Because geothermal powerplants will probably be built in small incremental units and because limited flexibility in siting is possible, most major problems should be avoided by careful planning. There may, in fact, be excellent opportunities to enhance wildlife habitat in the vicinity of geothermal developments if potential problems and opportunities are recognized early. Studies aimed at resolving such issues are currently underway in several KGRAs, and they will be needed as development expands into new areas.

Land use conflicts have also occurred in The Geysers region where development is encroaching upon residential areas. This problem, in theory at least, could be resolved by comprehensive land use planning in advance of development, and Federal aid in this process might be appropriate. In 
practice, however, this is a very difficult issue because land use management can result in major economic impacts on individuals and corporations, and local agencies have historically shown strong antagonism to State and Federal "assistance" in land use planning.

\section{Social Services and Community Structure}

Hydrothermal resources are located in a variety of areas with greatly differing socioeconomic resources. Many social, economic, cultural, and political issues may arise as geothermal energy uses are planned; these will be highly site specific. The Geysers powerplant has been opposed by some segments of the population in nearby communities because it threatens to alter a rural, retirement, and recreationally oriented lifestyle. The Imperial Valley resources are located within a highly developed agricultural system; however, a recent public opinion survey indicates that geothermal energy. development is highly favored by more than 90 percent of the populace. Competition for land and water resources may ultimately develop between agriculture and geothermal energy unless the development is carefully plannned to avoid such conflicts.

The development of geothermal resources will provide many positive impacts in the social and economic areas. Tax bases will be broadened and the economic base in affected communities will also be diversified. Early planning with affected communities could be effective in developing appropriate manpower resources so that positive steps can be taken to reduce local unemployment."

Geothermal projects will probably occur as phased development with exploration leading to the construction of power generating units, or nonelectric uses, in modest size increments. (Typical power generating units have been added at The Geysers in increments of about 100 MWe.) These phased developments should not result, therefore, in the overwhelming of existing social services that has occurred where very large coal-fired powerplants have been built.

Cultural and religious conflicts may also arise. Some hot springs have been or are being used as part of a cultural tradition, and development may be opposed because it threatens such use. Developmen't in Hawaii faces a unique problem because volcanoes (and geothermal energy) are considered by native Hawaiians to be physical manifestations of the Goddess Pele.

Because social, economic, cultural, and political issues may be significant in determining the acceptability of geothermal resource development, these potential issues must be identified and addressed. Development scenarios must be formulated and potential impacts identified. Effective mitigation of these issues will require working with or providing assistance to local communities so that the need for increased social services can be identified and planned, and the appropriate cultural and political issues can be identified and resolved in advance of development. 


\section{System Safety and Occupational Health}

The health and safety issues that affect the operation of hydrothermal energy facilties include the need for measures to ensure that the operation of such facilities adequately provides for the medical and health surveillance and safety of the workers at the facility.

The safety of geothermal energy extraction and utilization systems could become a major issue if early significant failures should occur. Well blowouts have occurred at several geothermal powerplants including The Geysers, California, and Cerro Prieto, Mexico. These events apparently have not caused major damage due to the isolated locations of the powerplants; however, such events could be serious.

Many proposed geothermal plant designs include secondary or tertiary loops with working fluids such as isobutane and propane. Containment of such fluids is important as they represent potentially explosive mixtures. In addition, many geothermal fluids are corrosive and erosive to standard materials. Because of such potential problems, there is a need for a detailed examination of the overall safety of geothermal energy systems. This review is in progress with a final report expected in FY 1979. This should be followed by the adoption of safety design and occupational health protection criteria.

\section{GEOPRESSURED SYSTEMS: CONCERNS, REQUIREMENTS, AND STATUS}

Table 3-4 lists the concerns and requirements for geopressured systems. The most significant are expected to be the disposal of spent geopressured fluids and land subsidence.

\section{Release of Airborne Effluents}

Fluids in geopressured reservoirs contain large amounts of dissolved (and perhaps' free) methane. This may, in fact, prove to be the most valuable part of the resource; it certainly will be recovered and used beneficially. In a recent geopressured well test, the dissolved gas contained, in addition to methane, about 1 percent $\mathrm{CO}_{2}$ and trace amounts of $\mathrm{H}_{2} \mathrm{~S}, \mathrm{Hg}$, $\mathrm{NH}_{3}$, and $\mathrm{Rn}$. Except for $\mathrm{NH}_{3}$, however, the concentrations found were quite low compared to noncondensable gases from hydrothermal systems. Results from other geopressured wells will be necessary before this potential problem can be assessed fully, but present results indicate that gas from geopressured wells can probably be added to other natural gas sources with no unusual treatment. Experience with some natural gas wells suggests that $\mathrm{H}_{2} \mathrm{~S}$ levels could be significantly higher in some areas and could constitute a problem. Large-scale development of the geopressured resource will result in the usual need for heat sinks and the accompanying problems of cooling tower drift, etc. 
Table 3-4. Environmental, Health, and Safety Concerns and Requirements for Geopressured Energy Systems

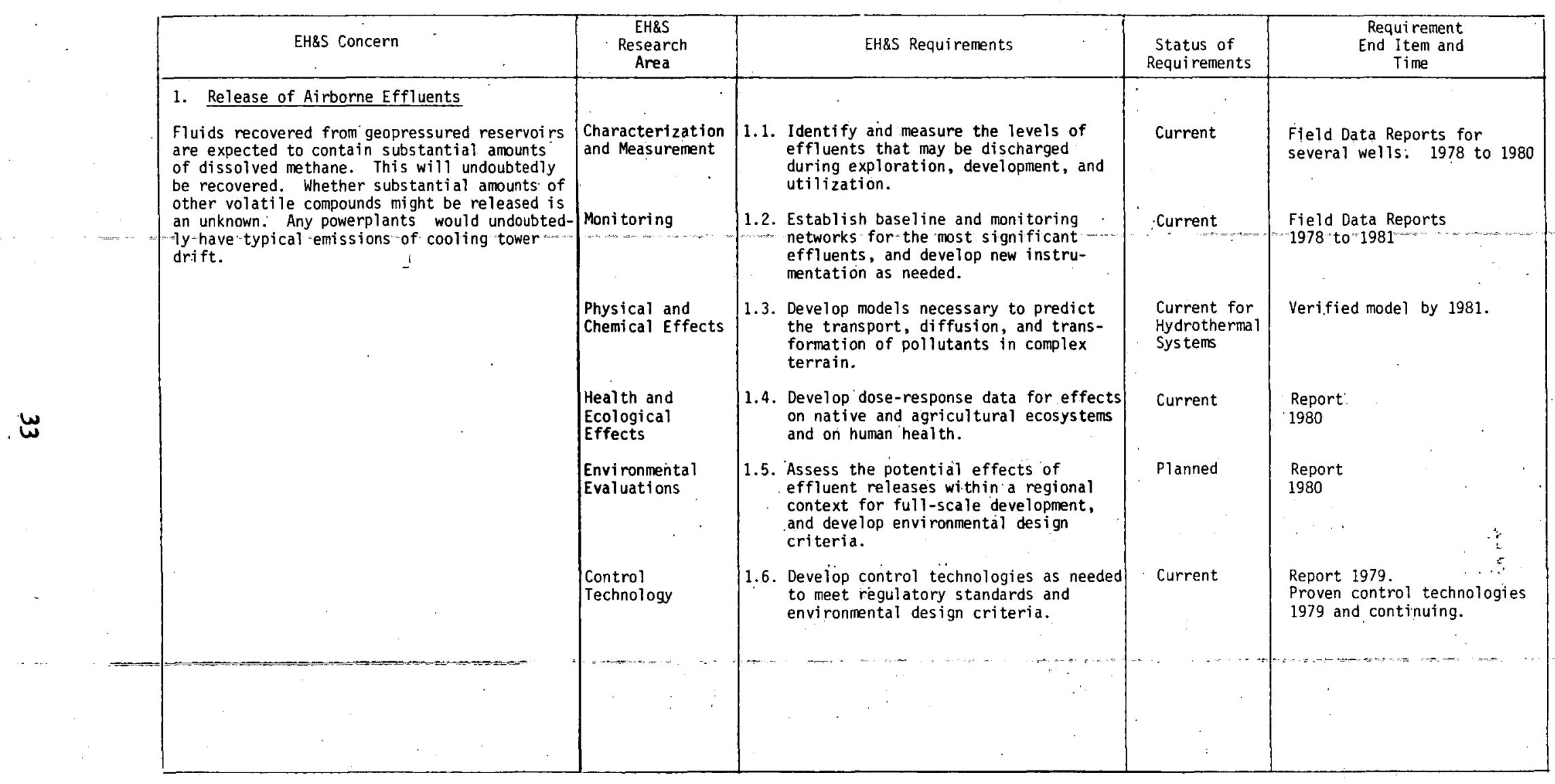


Table 3-4. Environmental, Health, and Safety Concerns and Requirements for Geopressured Energy Systems (Continued)

\begin{tabular}{|c|c|c|c|c|}
\hline EH\&S Concern & $\begin{array}{l}\text { EH\&S } \\
\text { Research } \\
\text { Area }\end{array}$ & EH\&S Requirements & $\begin{array}{c}\text { Status of } \\
\text { Requirements }\end{array}$ & $\begin{array}{l}\text { Requi rement } \\
\text { End Item and } \\
\text { Time }\end{array}$ \\
\hline \multicolumn{5}{|l|}{ 2. Release of Waterborne Effluents } \\
\hline \multirow{6}{*}{$\begin{array}{l}\text { Large volumes of geopressured fluids will } \\
\text { be produced. It may not be economically } \\
\text { feasible to inject these back into the reser- } \\
\text { voir, and other acceptable disposal means } \\
\text { must be found. The fluids may contain sub- } \\
\text { stantial amounts of dissolved solids. }\end{array}$} & $\begin{array}{l}\text { Characterization } \\
\text { and Measurement }\end{array}$ & $\begin{array}{l}\text { 2.1. Identify and measure the levels of } \\
\text { effluents that may be discharged } \\
\text { during exploration, development, and } \\
\text { utilization. }\end{array}$ & Current & $\begin{array}{l}\text { Field Data Reports for } \\
\text { severa? wells. } \\
1978 \text { to } 1980\end{array}$ \\
\hline & Monitoring & $\begin{array}{l}\text { 2.2. Establish baseline and monitoring } \\
\text { networks for the most significant } \\
\text { effluents, and develop new instru- } \\
\text { mentation as needed. }\end{array}$ & Current & $\begin{array}{l}\text { Field Data Reports } \\
1980 \text { to } 1981\end{array}$ \\
\hline & $\begin{array}{l}\text { Health and } \\
\text { Ecological } \\
\text { Effects }\end{array}$ & $\begin{array}{l}\text { 2.3. Develop dose-response data for } \\
\text { effects on aquatic ecosystems and } \\
\text { human health. }\end{array}$ & Current & $\begin{array}{l}\text { Report } \\
1980\end{array}$ \\
\hline & $\begin{array}{l}\text { Environmental } \\
\text { Evaluations }\end{array}$ & $\begin{array}{l}\text { 2.4. Assess the potential effects of } \\
\text { effluent releases within a regional } \\
\text { context for full-scale development, } \\
\text { and develop envi ronmental design } \\
\text { criteria. }\end{array}$ & Current & $\begin{array}{l}\text { Report } \\
1980\end{array}$ \\
\hline & $\begin{array}{l}\text { Environmental } \\
\text { Evaluations }\end{array}$ & $\begin{array}{l}\text { 2.5. Assess the consequences of accidental } \\
\text { releases of effluents. }\end{array}$ & Current & $\begin{array}{l}\text { Report } \\
1980\end{array}$ \\
\hline & $\begin{array}{l}\text { Control } \\
\text { Technology }\end{array}$ & $\begin{array}{l}\text { 2.6. Develop control technologies (surface } \\
\text { and subsurface) as needed to meet } \\
\text { regulatory standards and environmenta) } \\
\text { design criteria. }\end{array}$ & Current & $\begin{array}{l}\text { State-of-the-Art Report } 1979 . \\
\text { Proven control technologies } \\
1979 \text { and continuing. }\end{array}$ \\
\hline 3. Noise & & & & \\
\hline $\begin{array}{l}\text { Uncontrolled noise associated with exploration, } \\
\text { drilling, well venting and testing, and } \\
\text { operational processes may reach high levels } \\
\text { and may have deleterious effects on human popu- } \\
\text { lations and local fauna. }\end{array}$ & $\begin{array}{l}\text { Environmental } \\
\text { Evaluations and } \\
\text { Control Technol. } \\
\text { ogy }\end{array}$ & $\begin{array}{l}\text { 3.1. Develop noise abatement technologies } \\
\text { as needed to meet noise ordinances } \\
\text { and standards and environmental de- } \\
\text { sign criteria. }\end{array}$ & Current & $\begin{array}{l}\text { State-of-the-Art Report } 1979 . \\
\text { Proven abatement technolo- } \\
\text { gies } 1979 \text { and continuing. }\end{array}$ \\
\hline
\end{tabular}


Table 3-4. Environmental, Health, and Safety Concerns and Requirements for Geopressured Energy Systems (Continued)

\begin{tabular}{|c|c|c|c|c|}
\hline EH\&S Concern & $\begin{array}{l}\text { EH\&S } \\
\text { Research } \\
\text { Area }\end{array}$ & EH\&S Requirements & $\begin{array}{l}\text { Status of } \\
\text { Requirements }\end{array}$ & $\begin{array}{l}\text { Requi rement } \\
\text { End Item and } \\
\text { Time }\end{array}$ \\
\hline \multicolumn{5}{|l|}{ 3. Noise (cont'd) } \\
\hline & $\begin{array}{l}\text { Characterization } \\
\text { and Measurement }\end{array}$ & $\begin{array}{l}\text { 3.2. Measure noise levels associated with } \\
\text { the drilling, completion, and testing } \\
\text { of geopressured wells. }\end{array}$ & Current & $\begin{array}{l}\text { Field Data Report } \\
1979\end{array}$ \\
\hline 4. Subsidence & & $\because$ & & $\because$ \\
\hline $\begin{array}{l}\text { The removal of large volumes of geopressured } \\
\text { fluid may result in subsidence: The effects } \\
\text { may be severe on the gulf coast where lands } \\
\text { overlying the reservoirs are only a few feet }\end{array}$ & Monitoring & $\begin{array}{l}\text { 4.1. Conduct preoperational and contin- } \\
\text { uing measurements to estabi ish. } \\
\text { rates of subsidence. }\end{array}$ & Current & $\begin{array}{l}\text { Field Data Reports } \\
1978 \text { to } 1981\end{array}$ \\
\hline above sea level. & $\begin{array}{l}\text { Physical } \\
\text { Effects }\end{array}$ & 4.2. Conduct subsidence research program. & Current & $\begin{array}{l}\text { Field Data Reports } \\
1978 \text { to } 1980\end{array}$ \\
\hline 5. Induced Seismicity & $\begin{array}{l}\text { Control Tech- } \\
\text { nology }\end{array}$ & $\begin{array}{l}\text { 4.3. Verify efficacy of subsidence con- } \\
\text { trol techniques as needed. }\end{array}$ & Planned & $\begin{array}{l}\text { Field Data Report } \\
1983\end{array}$ \\
\hline $\begin{array}{l}\text { The withdrawal and possible injection of } \\
\text { geopressured fluids may produce seismic } \\
\text { events. } \\
\text { 6. Water Use }\end{array}$ & Monitoring. & $\begin{array}{l}\text { 5.1. Conduct preoperational and continuing } \\
\text { measurements to establish if the } \\
\text { testing of geopressured wells pro- } \\
\text { duces seismic events. }\end{array}$ & Current & $\begin{array}{l}\text { Field Data Reports } \\
1978 \text { to } 1981\end{array}$ \\
\hline $\begin{array}{l}\text { The development of geopressured reservoirs } \\
\text { will result in the consumption of water for } \\
\text { heat-rejection systems. }\end{array}$ & $\begin{array}{l}\text { Socioeconomic } \\
\text { Effects }\end{array}$ & $\begin{array}{l}\text { 6.1. Assess potential limitations on } \\
\text { geopressured resource development } \\
\text { due to water resource limitations. }\end{array}$ & Planned & $\begin{array}{l}\text { Field Data Report for each } \\
\text { region } \\
1980\end{array}$ \\
\hline$\therefore$ & . . & $\therefore$ & & \\
\hline
\end{tabular}


Table 3-4. Environmental, Health, and Safety Concerns and Requirements for Geopressured Energy Systems (Continued)

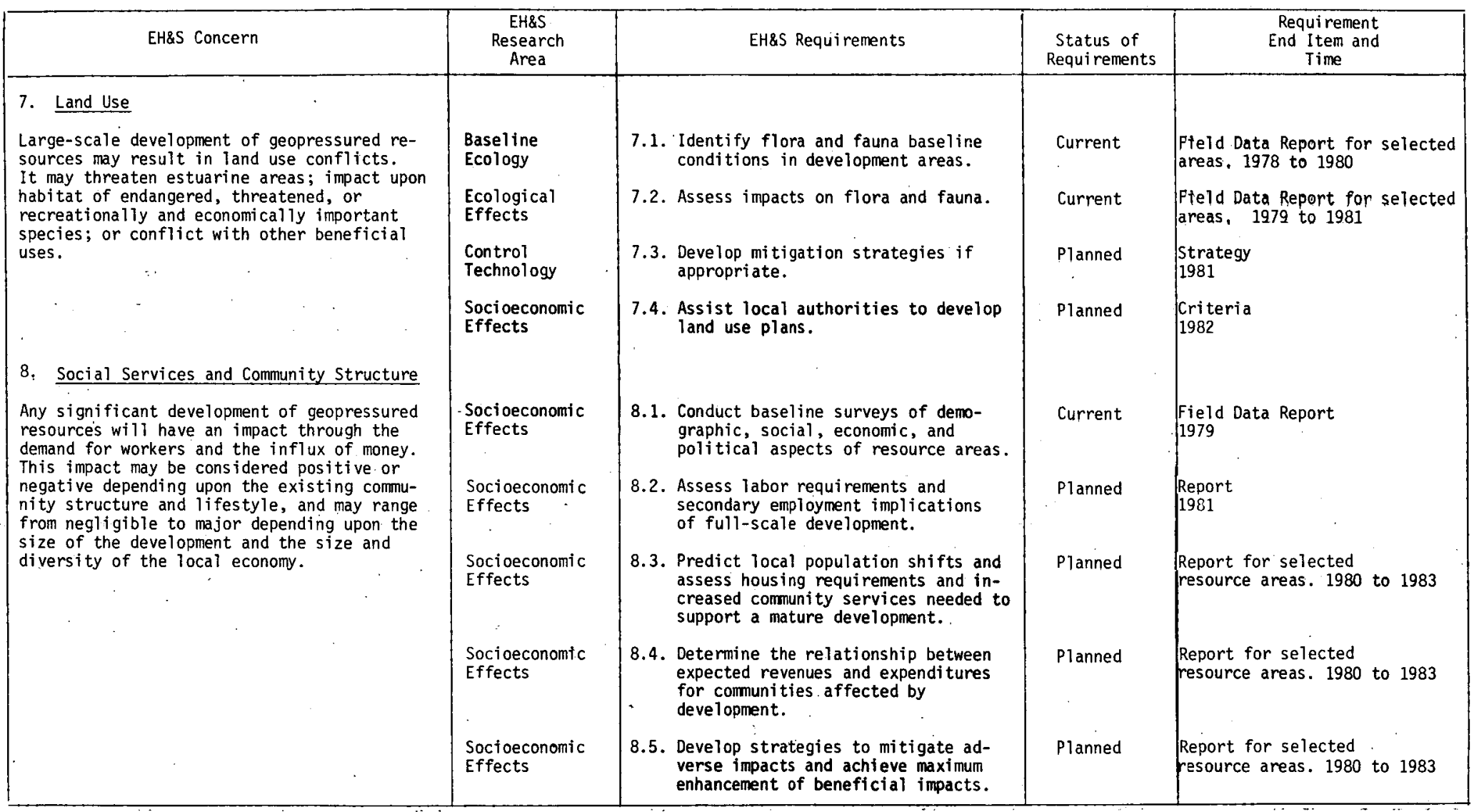


Table 3-4. Environmental, Health; and Safety Concerns and Requirements for Geopressured Energy Systems (Continued)

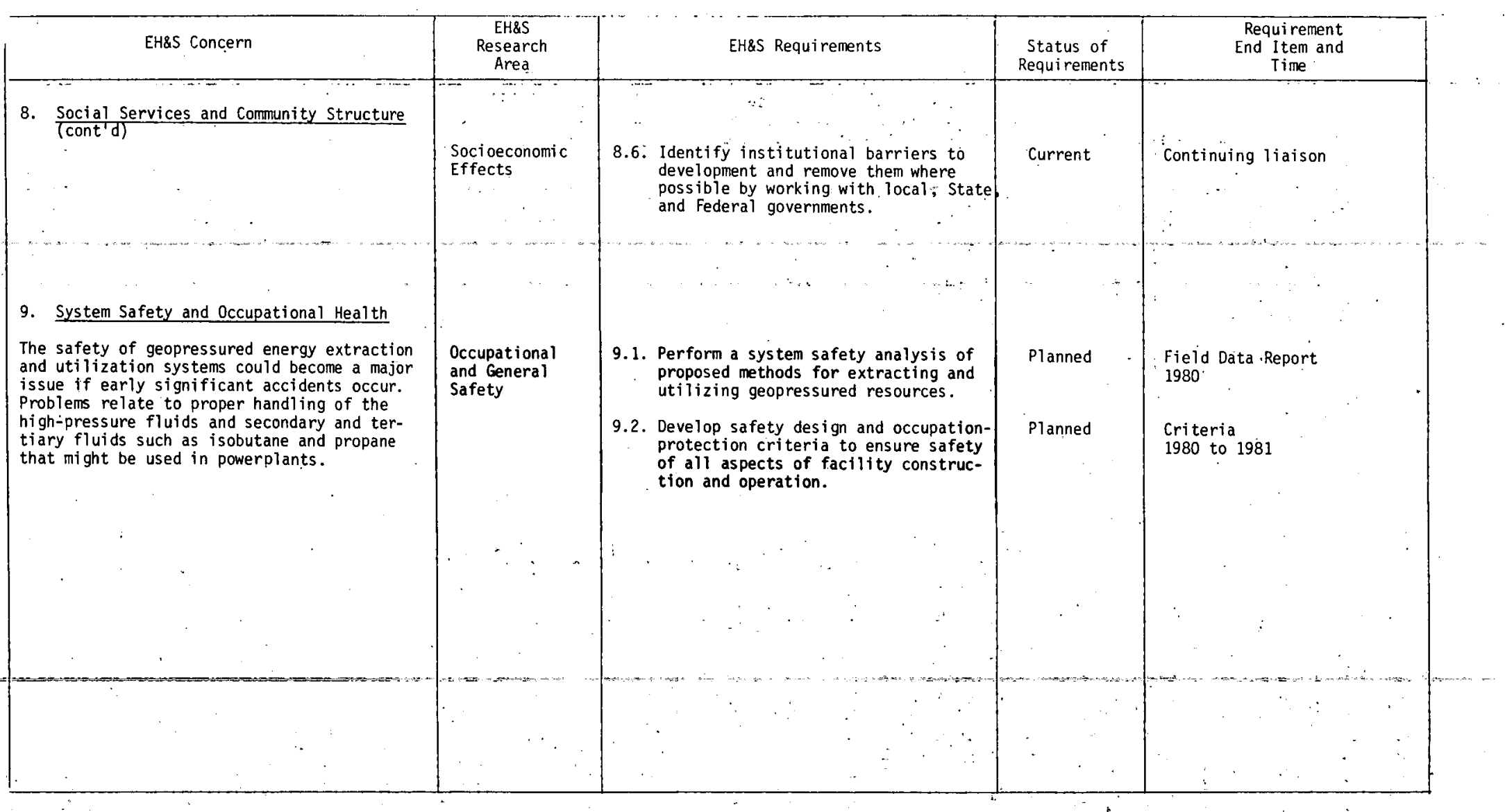




\section{Release of Waterborne Effluents}

Disposal of spent geopressured fluids will be one of the most significant environmental problems. Available analyses indicate that the fluid will have a total dissolved solids content of 1,000 to $10,000 \mathrm{ppm}$, and boron concentrations of 20 to $60 \mathrm{ppm}$. Other than possible feedstock for mineral recovery, the fluids will not be suitable for beneficial uses. Because of the great depths and pressures, it may not be economically feasible to inject the fluids back into the geopressured reservoir. Possible means of disposal are to discharge into existing saline bodies of water or to inject into subsuface saline aquifers. Both methods appear to be feasible, but carry environmental risks that must be evaluated carefully.

Disposal to surface bodies of waters, such as the Gulf of Mexico, must be done without endangering the wetlands ecosystem, which is important to the region's economy. Subsurface disposal is currently being used with oilfield brines, but a fully developed geopressured industry. would generate a substantially larger volume of brines. Long-term questions of reservoir acceptance without the contamination of aquifers of beneficial use must be answered, and monitoring networks will be essential.

As with some hydrothermal fluids, long-term injection may not be possible without the treatment of the brines to remove solids that would plug the wellbore or reservoir. If treatment is necessary, this may produce large volumes of solid waste that will require disposal. Tests scheduled over the next several years should define the extent of this possible problem. The discharge of cooling tower blowdown will probably also be required.

\section{Noise}

$\backslash$ Because of the pressures involved, production facilities will be inherently noisy. However, noise levels should be substantially less than those associated with a freely venting well at The Geysers. Actual noise measurements will be required, and research on abatement systems may be needed.

\section{Subsidence}

The withdrawal of large volumes of fluid from geopressured reservoirs will result in compaction of the reservoir at depth. This compaction may be translated to the surface and result in land subsidence, but this is not known with certainty. If subsidence should occur, the results along the gulf coast are potentially very serious. This is because a large amount of land is presently only a few feet above sea level. Significant subsidence could result not only in the direct inundation of land but could also make large areas susceptible to flooding due to hurricane activity or freshwater flooding.

Regional and site-specific leveling networks are essential to measure this potential effect, and resurveying should be performed periodically. A better understanding of the process of subsidence, and the factors that control it, is essential. 


\section{Induced Seismicity}

The induction of seismic events by the production of geopressured reservoirs is not considered likely, but cannot be ruled out. The gulf coast area is generally aseismic, and there appears to be a slow and continuous release of stress along the many growth faults in the region. The reduction of pore pressure in geopressured reservoirs could conceivably alter this process and cause stresses to accumulate. Seismic activity and fault movement should therefore be monitored closely during development.

\section{Water Use}

Large-scale development of the geopressured resource could result in competitive demands for the better quality water supplies. The required heat rejection systems are projected to be net consumers of water even if the condensate water is used for cooling water makeup. Careful advance planning should be able to resolve this problem, although in some areas it may be necessary to use saline water for cooling.

\section{Land Use}

A potentially serious issue concerns development in coastal wetlands. This wetlands area is sensitive to disruptions from human activities and is unusually valuable in terms of commercial productivity, recreation, and cultural and scientific interest. Coastal Zone Management Plans may be enacted that could have significant impacts on how the geopressured resource can be developed in these areas. A more thorough understanding of the biology and hydrology of the wetlands area will be reqired so that appropriate mitigation measures may be taken. More data on the presence of threatened and endangered species in these areas will also be required.

\section{Social Services and Community Structure}

A mature geopressured industry could have a significant impact upon regional economics and community structure. However, the gulf coast area has generally experienced large-scale industrial development and can probably accommodate the phased type of development that would occur. Some exceptions may arise where community assistance would be appropriate:

Major political and legal problems will arise if subsidence should actually occur or if there is significant disruption of wetlands ecosystems. The development of appropriate regulations in advance of large-scale activities would help mitigate public concern.

\section{System Safety and Occupational Health}

Well blowouts and accidental spills of produced fluids could have substantial impacts. Due to the pressures involved, well blowouts may be very difficult to control. A thorough assessment of the safety of any proposed geopressured fluid utilization facility must be carried oult. 


\section{E. HOT DRY ROCK SYSTEMS: CONCERNS, REQUIREMENTS, AND STATUS}

Concerns and requirements for hot dry rock systems are presented in Table 3-5. These concerns are somewhat speculative due to the very limited experience even with experimental systems. The most significant concerns may be the induction of seismic events and water use conflicts.

\section{Release of Airborne Effluents}

The extraction of energy from hot dry rock systems will depend upon the use of an exogenous fluid. Current experiments at Fenton Hill, New Mexico, are using water which is being circulated through a fractured section of rock via two wells. In theory, a closed circulation loop is possible, but it is necessary to vent the fluid when circulation is restarted. In addition, because the water does dissolve some of the rock, it may be necessary to discharge blowdown from the circulation system to control the buildup of dissolved solids. These processes. will also result in the discharge of dissolved gases that may be present in the fluid. Measurements at Fenton Hill indicate that $\mathrm{CO}_{2}, \mathrm{H}_{2} \mathrm{~S}$, traces of $\mathrm{NH}_{3}$, and additional unidentified gases are present. The levels of $\mathrm{H}_{2} \mathrm{~S}$ and $\mathrm{NH}_{3}$ found do not suggest that these releases will be a significant environmental problem, but more data are needed as extraction experiments in other areas progress.

As with any energy technology, cooling tower drift effects represent a potential impact that must be assessed if wet cooling towers are to be used. Initial experiments involve discharging the heat directly to the atmosphere.

\section{Release of Waterborne Effluents}

As discussed above, the circulating fluid will dissolve or leach material from the fractured rock. The experiments at Fenton Hill indicate that silica may build up in the fluid to such an extent that treatment may be required to remove the silica to eliminate fouling of the heat extraction system. One method might be to discharge blowdown from the system if makeup water is available. Another method might be to remove the silica; this would result in a solid. or slurry waste disposal problem. Other chemicals such as fluorides and mercury might also be present in this waste.

\section{Noise}

Heat extraction processes are not anticipated to be unusually noisy. However, noise levels: associated with drilling and general activity may be objectionable in some locations.

\section{Subsidence}

Fractured:volumes will not be very large (several hundred meters thick) and will be created at great depth (about 3500 meters). Overlying competent rock is expected to provide sufficient support so that subsidence should 
Table 3-5. Environmental, Health, and Safety Concerns and Requirements for Hot Dry Rock Energy Systems

\begin{tabular}{|c|c|c|c|c|}
\hline$\therefore$ EH\&S Concern & $\begin{array}{l}\text { EH\&S } \\
\text { Research } \\
\text { Area }\end{array}$ & EH\&S Requirements & $\begin{array}{l}\text { Status of } \\
\text { Requirements }\end{array}$ & $\begin{array}{l}\text { Requi rement } \\
\text { End I tern and } \\
\text { Time }\end{array}$ \\
\hline 1. Release of Airborne Effiuents & & & & \\
\hline $\begin{array}{l}\text { Exogenous fluids will be used to extract. } \\
\text { energy from hot dry rock strata. These } \\
\text { fluids may leach volatile compounds from } \\
\text { these strata or cause chemical reactions that } \\
\text { will result in the presence of dissolved } \\
\text { gases: It may be neces'sary to release these } \\
\text { gases to the atmosphere; cooling tower drift } \\
\text { would perhaps also be a problem. }\end{array}$ & $\begin{array}{l}\text { Characterization } \\
\text { and Measurement } \\
\text { Monitoring }\end{array}$ & $\begin{array}{l}\text { 1.1. Identify and measure the levels of } \\
\text { effluents that may be discharged } \\
\text { during exploration, development, and } \\
\text { utilization. } \\
\text { 1.2. Establish baseline and monitoring } \\
\text { networks for the most significant } \\
\text { effluents, and develop new instru- } \\
\text { mentation as needed: }\end{array}$ & $\begin{array}{l}\text { Current } \\
\text { Planned }\end{array}$ & $\begin{array}{l}\text { Field Data Report for each } \\
\text { experiment. } 1978 \text { to } 1985 \\
\text { Field Data Reports } \\
1980 \text { to } 1985\end{array}$ \\
\hline . & $\begin{array}{l}\text { Physical and } \\
\text { Chemical Effects }\end{array}$ & $\begin{array}{l}\text { 1.3. Develop models necessary, to predict } \\
\text { the transport, diffusion, and trans- } \\
\text { formation of pollutants in complex } \\
\text { terrain. }\end{array}$ & $\begin{array}{l}\text { Current for } \\
\text { Fiydrothermal } \\
\text { Systems }\end{array}$ & Verified model by 1981. \\
\hline & $\begin{array}{l}\text { Heal th and } \\
\text { Ecological } \\
\text { Effects }\end{array}$ & $\begin{array}{l}\text { 1.4. Develop dose-response data for effects } \\
\text { on native and agricultural ecosystems } \\
\text { and on human health. }\end{array}$ & Current & $\begin{array}{l}\text { Report } \\
1981\end{array}$ \\
\hline 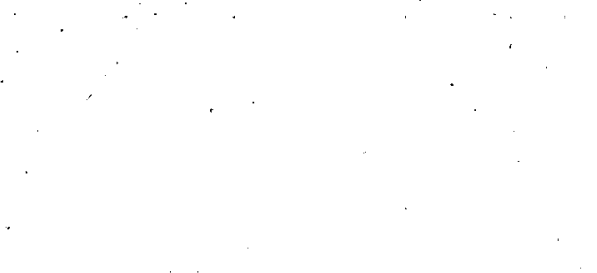 & $\begin{array}{l}\text { Environmental } \\
\text { Evaluations } \\
\text { Control : } \\
\text { Technology }\end{array}$ & $\begin{array}{l}\text { 1.5. Assess the potential effects of } \\
\text { effiuent releases within a regional- } \\
\text { context for full-scale development, } \\
\text { and develop environmental design } \\
\text { criteria. } \\
\text { 1.6. Develop control technologies as needed } \\
\text { to meet regulatory standards and } \\
\text { environmental design criteria. }\end{array}$ & $\begin{array}{c}\text { Planned } \\
\text { Planned }\end{array}$ & $\begin{array}{l}\text { Report } \\
1985 \\
\ddots \\
\text { Proven control technologies } \\
\text { Post-1985 }\end{array}$ \\
\hline$\cdots$ & & $\ldots$ & & $\cdot \quad: \quad:$ \\
\hline$\therefore \quad$. & & $\therefore \quad \therefore \quad-\cdots$ & & $\therefore \quad(\quad-1$ \\
\hline
\end{tabular}


Table 3-5. Environmental, Health, and Safety Concerns and Requirements for Hot Dry Rock Energy Systems (Continued)

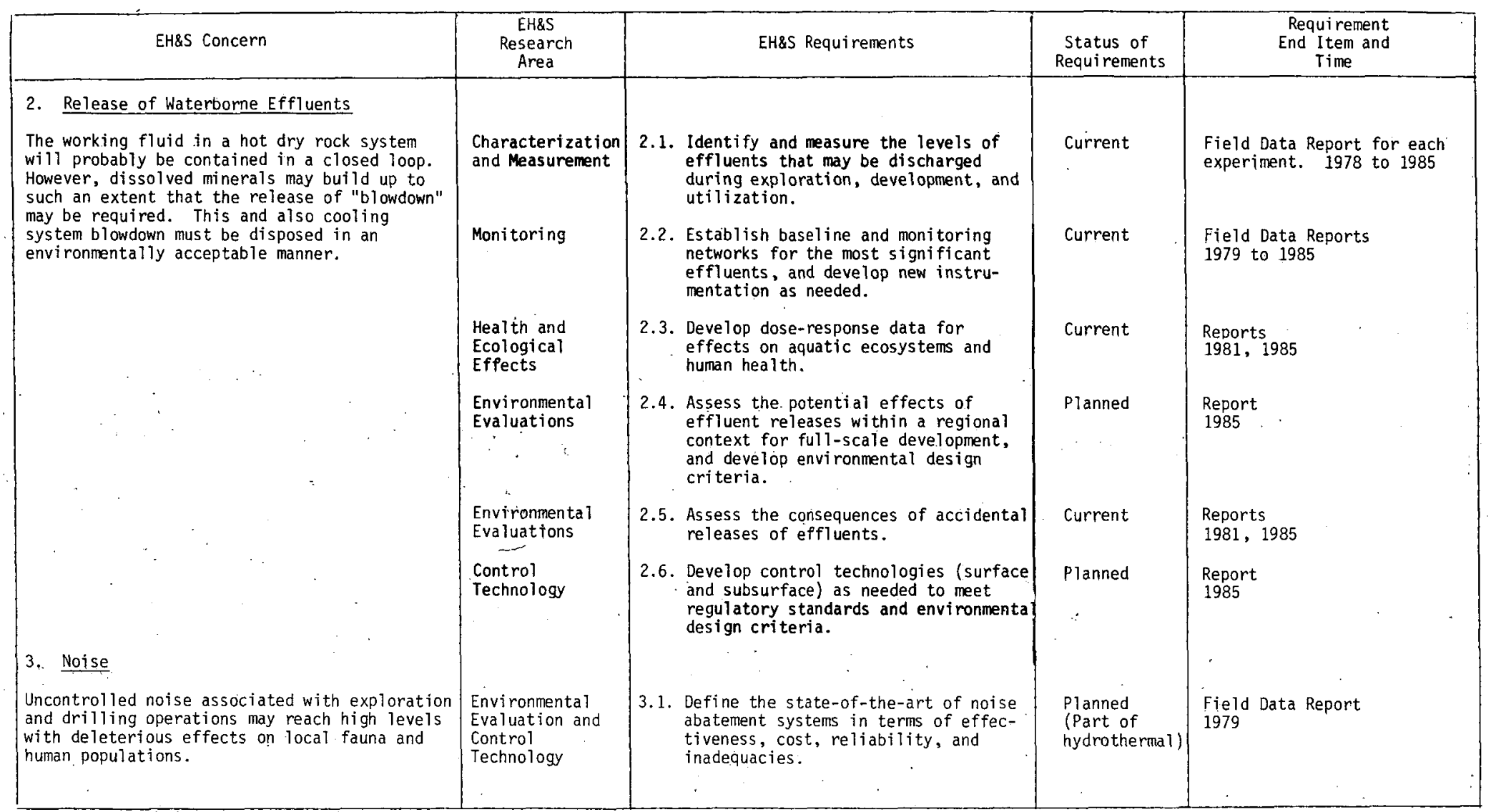


Table 3-5. Environmental, Health, and Safety Concerns and Requirements for Hot Dry Rock Energy Systems (Continued)

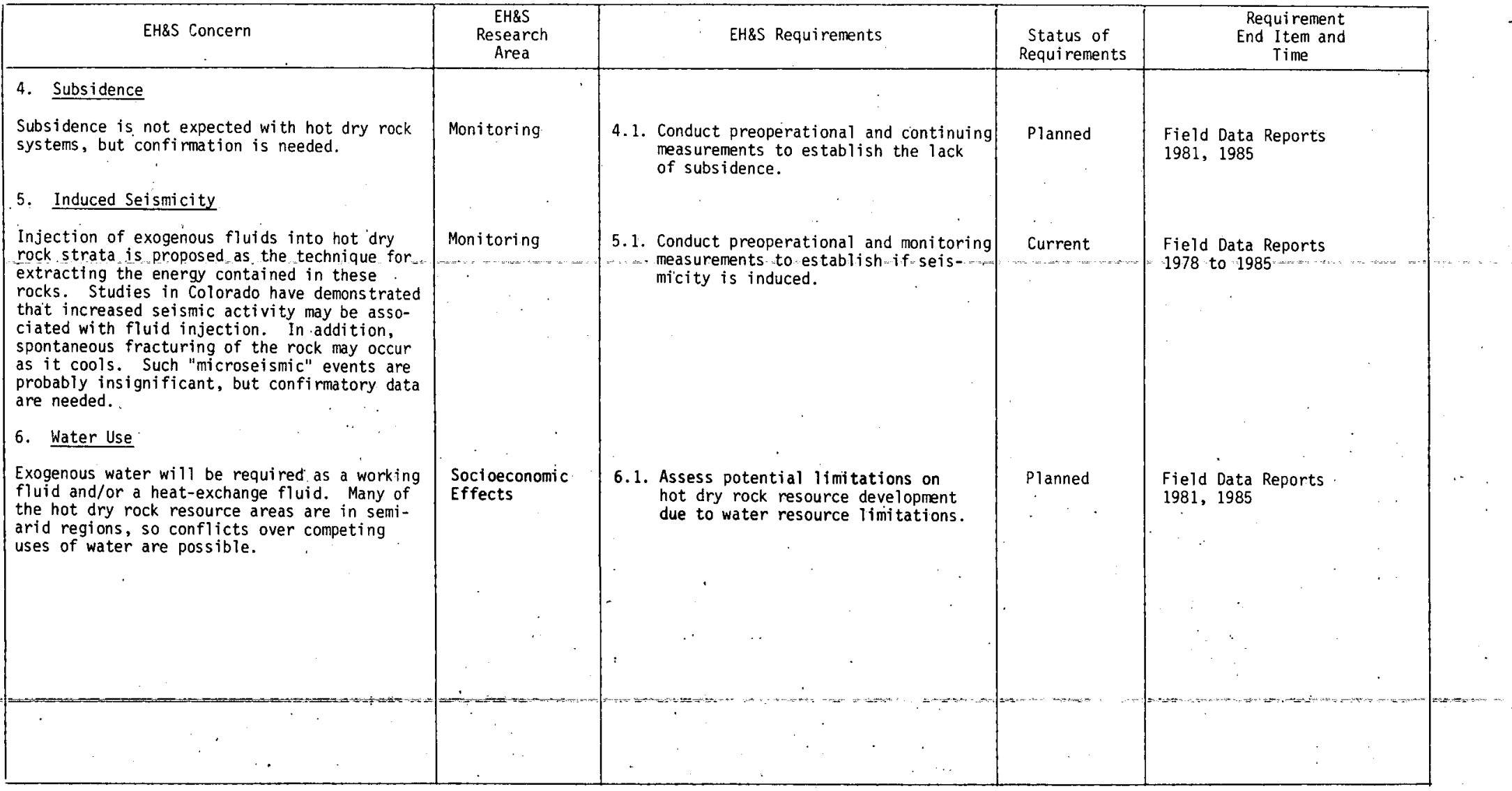

$\checkmark$ 
Table 3-5. Environmental, Health, and Safety Concerns and Requirements for Hot Dry Rock Energy Systems (Continued)

\begin{tabular}{|c|c|c|c|c|}
\hline EH\&S Concern & $\begin{array}{l}\text { EH\&S } \\
\text { Research } \\
\text { Area. }\end{array}$ & EH\&S Requirements & $\begin{array}{l}\text { Status of } \\
\text { Requirements }\end{array}$ & $\begin{array}{l}\text { Requi rement } \\
\text { End Item and } \\
\text { Time }\end{array}$ \\
\hline \multicolumn{5}{|l|}{ 7. Land Use } \\
\hline \multirow{4}{*}{$\begin{array}{l}\text { Development plans may be opposed because of } \\
\text { land use conflicts. They may threaten pris- } \\
\text { tine wilderness areas; impact upon habitat } \\
\text { of endangered, threatened, or recreationalily } \\
\text { important species; or conflict with other } \\
\text { beneficial uses. }\end{array}$} & $\begin{array}{l}\text { Baseline } \\
\text { Ecology }\end{array}$ & $\begin{array}{l}\text { 7.1. Identify flora and fauna baseline } \\
\text { conditions in development areas. }\end{array}$ & Planned & $\begin{array}{l}\text { Field Data Report for each } \\
\text { site. } 1980 \text { to } 1982\end{array}$ \\
\hline & $\begin{array}{l}\text { Ecological } \\
\text { Effects }\end{array}$ & 7.2. Assess impacts on flora and fauna. & Planned & $\begin{array}{l}\text { Field Data Report for each } \\
\text { site. } 1980 \text { to } 1982\end{array}$ \\
\hline & $\begin{array}{l}\text { Control } \\
\text { Technology }\end{array}$ & $\begin{array}{l}\text { 7.3. Develop mitigation strategies if } \\
\text { appropriate. }\end{array}$ & Planned & $\begin{array}{l}\text { Strategy for each site. } \\
1980 \text { to } 1982\end{array}$ \\
\hline & $\begin{array}{l}\text { Socioeconomic } \\
\text { Effects }\end{array}$ & $\begin{array}{l}\text { 7.4. Assist local authorities to develop } \\
\text { land use plans. }\end{array}$ & Planned & $\begin{array}{l}\text { Criteria } \\
1981\end{array}$ \\
\hline 8. Social Services and Community Structure & & & · & \\
\hline $\begin{array}{l}\text { Significant development of the hot dry rock } \\
\text { resource will have an impact through the de- } \\
\text { mand for workers and the influx of money. } \\
\text { This impact may be positive or negative de- } \\
\text { pending upon the existing community structure } \\
\text { and lifestyle, and may range from negligibie } \\
\text { to major depending upon the size of the de- } \\
\text { velopment and the size and diversity of the } \\
\text { local economy. } \\
\text { 9. System Safety and Occupational Health }\end{array}$ & $\begin{array}{l}\text { Socioeconomic } \\
\text { Effects }\end{array}$ & $\begin{array}{l}\text { 8.1. Conduct preliminary assessments of } \\
\text { potential impacts on social services } \\
\text { and community structure. }\end{array}$ & Planned & $\begin{array}{l}\text { Reports } \\
1981,1985\end{array}$ \\
\hline $\begin{array}{l}\text { The safety of hot dry rock energy extraction } \\
\text { and utilization systems could become a major } \\
\text { issue if early significant accidents occur. } \\
\text { Secondary loops may contain isobutane or other }\end{array}$ & $\begin{array}{l}\text { Occupational } \\
\text { and General } \\
\text { Safety }\end{array}$ & $\begin{array}{l}\text { 9.1. Perform a system safety analysis of } \\
\text { proposed methods for extracting and } \\
\text { utilizing geopressured resources. }\end{array}$ & Planned & $\begin{array}{l}\text { Report } \\
1981\end{array}$ \\
\hline $\begin{array}{l}\text { explosive fluids which are a potential onsịte } \\
\text { hazard. }\end{array}$ & $\begin{array}{l}\text { Occupational } \\
\text { and General } \\
\text { Safety }\end{array}$ & $\begin{array}{l}\text { 9.2. Develop safety design and occupation- } \\
\text { protection criteria to ensure safety } \\
\text { of all aspects of facility construc- } \\
\text { tion and operation. }\end{array}$ & Planned & $\begin{array}{l}\text { Criteria } \\
1982\end{array}$ \\
\hline$\therefore \quad \therefore$ & & 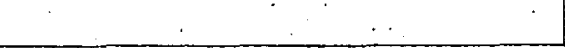 & & $=$ \\
\hline
\end{tabular}


not occur. However, significant experiments should include minimum subsidence detection networks to confirm this.

\section{Induced Seismicity}

Massive fluid injection and withdrawal with the accompanying cooling of rock may lead to increased levels of seismic activity. Measurements during the initial experiments at Fenton Hill have not detected any increase in seismic activity; however, measurements should be continued as the experiments increase in scope.

\section{Water Use}

Although other working fluids have received some consideration, water will probably be the fluid of choice. An initial volume of water will be required to establish circulation, and makeup water will be needed to compensate for fluid loss in the system. Additional water may be required if blowdown from the system is discharged or if wet cooling systems are used as heat rejection systems. Detailed assessments of water needs and of possible conflicts over water use will be required.

\section{Land Use}

Conflicts may arise over land use if proposed experiments or developments impinge on wilderness areas; impact upon habitats of endangered, threatened, or recreationally important species; or conflict. with other beneficial uses. As significant development will not occur for several years, this problem should be avoidable by care in the site selection process for experimental sites.

\section{Social Services and Community Structure}

As with any energy development, potential impacts upon local communities may occur. Over the next several years, only a few experiments will be conducted and effects should be minor. As decision points for commercialization are approached, assessments of the impacts of large-scale development will be required.

\section{System Safety and Occupational Health}

As practical heat extraction processes become defined, a review of system safety and possible occupational health problems should be undertaken. No unusual problems are anticipated, but secondary loops containing isobutane or other combustible fluids may be utilized and will require special attention. 


\section{ENVIRONMENTAL PROGRAM STRATEGY AND MANAGEMENT}

\section{A. PROGRAM GOAL}

The goal of the DOE Environmental Program is to ensure that energy technologies developed, demonstrated, and brought to the commercialization phase by DOE are environmentally acceptable. In particular, ensuring environmental acceptability refers not only to meeting the present, immediate requirements of the law but also to identifying environmental problems and taking measures that will avoid or mitigate adverse effects of widespread and long-term use of these technologies.

Section III enumerated and discussed the various environmental concerns and the $R \& D$ required. This section describes the implementation strategy developed to, address these needs.

\section{B. PROGRAM STRÄTEGY}

To accomplish the above-stated goal, DOE conducts a number of assessments to determine the EH\&S implications of energy technology development and utilization. The results of these assessments provide the basis for the DOE program addressing the concerns and requirements described in Tables $3-3,3-4$, and $3-5$. The current program is designed to

- Produce information that will define the nature and scope of potential EH\&S impacts,

- Provide an information base for the establishment of EH\&S standards and regulations,

- Ensure that environmental considerations are taken into account in the program decisionmaking process, and

- Define mitigation measures and develop appropriate control technology to minimize impacts and meet environmental standards at reasonable cost.

The EH\&S program consists of numerous projects, which are generally grouped as follows:

- Baseline characterizations to identify potential impacts and to establish the environmental conditions before significant development takes place;

- Operational site measurements and monitoring to assess environmental conditions during resource development and energy production operations; 
- Effects studies to evaluate the ecological, health, safety, social, and economic impacts of geothermal developments and to develop the capability to predict long-term consequences;

- Integrated assessment and evaluation of our knowledge concerning the issues;

- Environmental control and abatement research to limit emissions and reduce impacts to prescribed or acceptable levels; and

- Development of EH\&S guidelines and performance criteria.

The current and planned research and assessment projects supporting the geothermal program are summarized in Appendix B. The projects listed have been developed, planned, and implemented in coordination with the Assistant Secretary for Energy Technology (ASET)/Energy Technology Solar, Geothermal, Electric, and Storage Systems (ETS), the Office of the Assistant Secretary for: Resource Applications (ASRA), and the Assistant Secretary for. Environment "(ASEV) to address "the concerns and requirements of Tables 3-3, 3-4, and 3-5.

Figure 4-1 presents the schedule for environmental $R \& D$ efforts and compliance activities, coordinated, with the schedule of the geothermal energy systems technology program. The upper section of the figure summarizes the total technology program (Figures 2-6/through 2-9) and establishes a time frame for the completion of systems and general technology development projects. Research on potential environmental impacts associated with stages of technology development is scheduled to precede completion of major systems and technology development projects, except in rare cases where the environmental $R \& D$ is necessarily of long-term duration. Preparation of Environmental Assessments (EAs) and Environmental Impact Statements (EISs) is similarly scheduled in Table 4-1. Revisions to the EAs and EISs will be scheduled in updated EDPs.

\section{PROGRAM MANAGEMENT}

\section{Responsibility}

ASEV, ETS, and ASRA are responsible for preparing, reviewing, approving, and coordinating implementation of this EDP. The Office of Environment (EV)/Division of Technology Assessment, ETS/Division of Planning and Technology Transfer, and the Office of Resource Applications/ Division of Geothermal Resource Management will coordinate in identifying and determining the priorities of major health and environmental issues and reviewing research and assessment activities for relevance and timeliness.

The primary responsibility for performing the environmental research and assessment activities related to geothermal technology development will be shared by ETS, RA, and EV. Each program office will initiate, fund, and manage its health and environmental research and assessment programs in support of high-priority needs enumerated in the EDP. Projects 


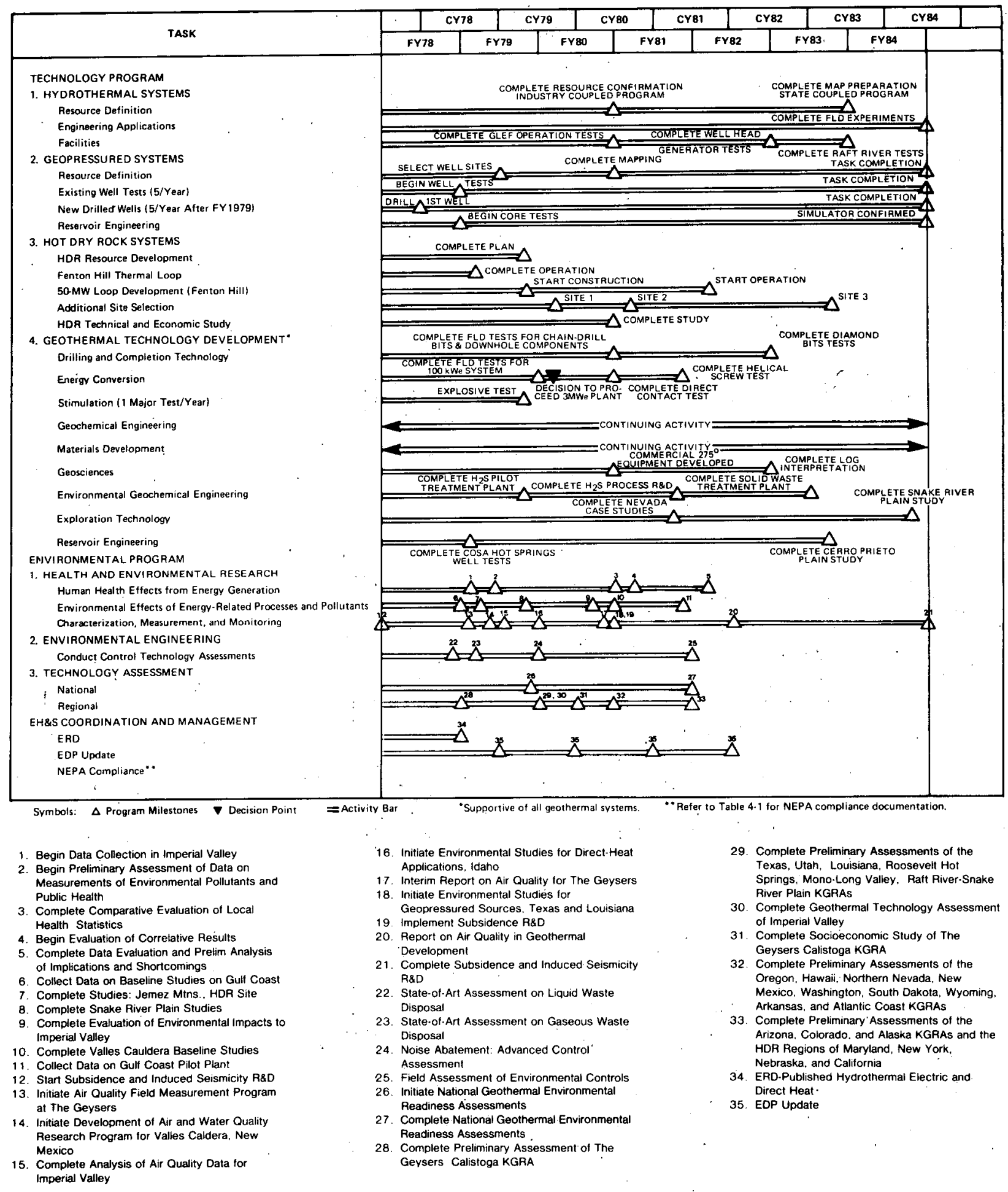

Figure 4-1. Coordinated Technology and Environmental Milestones 
Table 4-1. Summary of DOE-Prepared NEPA-Related Documents

\begin{tabular}{|c|c|c|c|}
\hline Project & Document Number & & Date \\
\hline 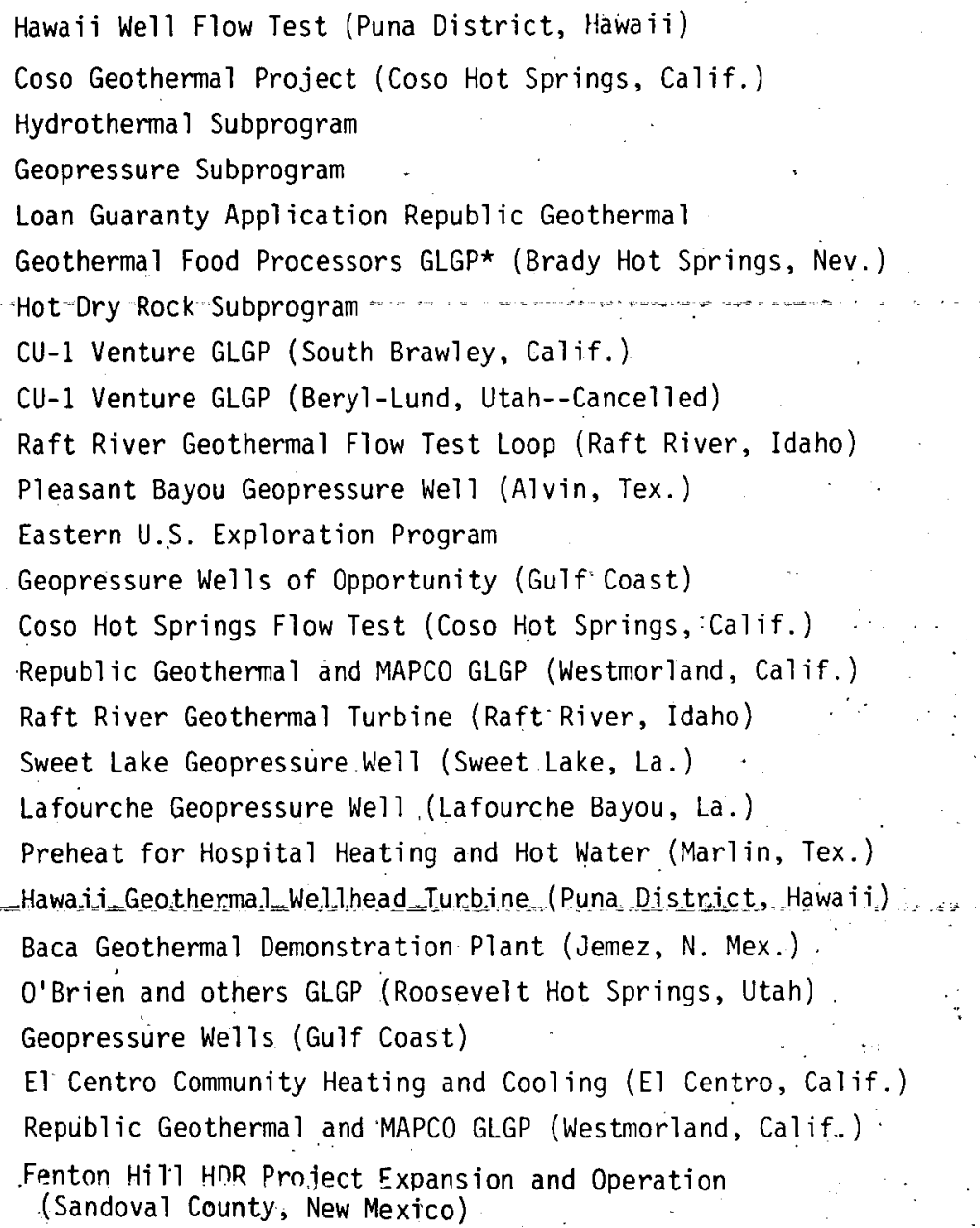 & $\begin{array}{l}\text { EIA/GE/76-1 } \\
\text { EIA/GE/77-1 } \\
\text { EIA/GE/77-2 } \\
\text { EIA/GE/77-3 } \\
\text { EIA/GE/77-4 } \\
\text { EIA/GE/77-5 } \\
\text { EIA/GE/77-6 } \\
\text { EIA/GE/77-7 } \\
\text { EIA/GE/77-8 } \\
\text { DOE/EA-0008 } \\
\text { DOE/EA-0013 } \\
\text { DOE/EA-0015 } \\
\text { DOE/EA-0023 } \\
\text { DOE/EA-0036 } \\
\text { EA Draft } \\
\text { EA Draft } \\
\text { EA Draft } \\
\text { EA Draft } \\
\text { EA Draft } \\
\text { EA Draft } \\
\text { EIS } \\
\text { EA } \\
\text { EA } \\
\text { EA } \\
\text { EIS } \\
\text { EA Draft } \\
\end{array}$ & & $\begin{array}{l}\text { Nov. } 1976 \\
\text { Jan. } 1977 \\
\text { March } 1977 \\
\text { July } 1977 \\
\text { May } 1977 \\
\text { Sept. } 1977 \\
\text { Sept. } 1977 \\
\text { Aug. } 1977 \\
\text { Sept. } 1977 \\
\text { March } 1978 \\
\text { March } 1978 \\
\text { April } 1978 \\
\text { Feb. } 1978 \\
\text { April } 1978 \\
\text { June } 1978 \\
\text { June } 1978 \\
\text { Sept: } 1978 \\
\text { Oct. } 1978 \\
\text { Oct. } 1978 \\
\text { Nov. } 1978 \\
\text { in preparation } \\
\text { in preparation } \\
2 \text { projected } \\
\text { projected } \\
\text { projected } \\
\text { March } 1979 \\
\end{array}$ \\
\hline
\end{tabular}

* GLGP. $=$ Geothermal Loan Guaranty Program 
implemented will be coordinated and reviewed by the Geothermal Environmental Coordination Committee (GECC) and its subcommittees, described below.

EV will concentrate on environmental and biological effects research and national impact assessments resulting from particular commercialization scenarios and assessment of control options; ETS will concentrate on resource assessment and development of environmental control technologies. ETS and RA will identify the need for and prepare appropriate NEPA documents at the earliest possible date to meet the intent of NEPA. EV will assist in determining the need for and the timing and will provide overall review and approval of the documents. EV, ETS, and RA will coordinate the activities of offices in DOE and other Government agencies to ensure that resources are employed optimally for geothermal-related environmental research and assessment. RA will be concerned with providing appropriate incentives for commercialization through such means as loan guaranties, direct grants, and occasionally through planning assistance to states with KGRAs.

\section{Coordination}

The Geothermal Environmental Coordination Committee is a special group constituted under authority of DOE Order 5420.1 , composed of representatives of various DOE offices to assist in the implementation of the DOE Environmental Development Plan System. The primary function of GECC is to monitor and overview the status of environmental $R \& D$ programs, ensure that the intent of the EDPs is achieved, and promote regular information exchanges and coordination between offices responsible for environmental R\&D. Specifically, GECC, through appropriate subcommittees,

- Participates in the preparation and review of EDPs and identifies the need for and recommends revisions in EDPs;

- Maintains a collective awareness of the content, status, and results of environmental $R \& D$ efforts and apprises management periodically of status and issues;

- Advises management of gaps, redundancies, and potential conflicts in the environmental $R \& D$ efforts and recommends corrective options for management considerations; and

$\because \quad$ Coordinates between performing offices those necessary physical and institutional arrangements required for the conduct of respective environmental research efforts.

\section{Management Documents}

In addition to EDPs, certain EH\&S documents are prepared to assist management in conducting DOE's environmental program. The most significant of these are briefly described below. 
Environmental Readiness Document - The ERD is an independent assessment report prepared by ASEV with the full cognizance of technology program line managers. It provides a state-of-the-art assessment of the environmental status of a technology at the phase of development being considered for management decisions, usually at the key decision points of the management system. The ERD presents the results of a critical review and analysis of environmental $: R \& D$ results carried on in the preceding phase and provides further definition of concerns and research needs for the ensuing period. The ERD provides the basis for the ASEV position on the environmental readiness of a DOE technology at each key decision point.

Environmental Assessment/Environmental Impact Statement - The National Environmental Policy Act of 1969 establishes the requirements for EISs. An EA is a statement that provides the information on which to base a determination of the necessity for an EIS or a finding of no significant impact. EAs may be prepared for any action and at any time to assist Departmental planning and decisionmaking. EAs and EISs are prepared by. program offices according to DOE procedures and are reviewed by the Office of Environment.

Safety Analysis - A safety analysis is prepared by program managers according to DOE procedures (Uniform Independent Safety Review System); early in the design phase of a proposed facility that DOE intends to procure and operate. The use of a safety analysis to identify hazards, eliminate and control identified hazards, assess residual risk, and document management authorization to a DOE operation applies equally to technology base activities and energy system acquisition projects. The purpose is to limit risks to the health and safety of the public and employees and adequately protect property and the environment. 


\section{BIBLIOGRAPHY.}

Adams, D.F., F.A. Young, and R.A. Luhr, Evaluation of an Odor Perception Threshold Test Facility," Tappi 51, 62A, 1968.

Anspaugh, L.R., "Final Report on the Investigation of the Impact of the Release of $222 \mathrm{Rn}$, Its Daughters, and Precursors at The Geysers Geothermal Field and Surrounding Area," Lawrence Livermore Laboratory, 1978.

Axtmann, R.C., "Emission Control of Gas Effluents from Geothermal Power Plants," Environmental Letters 8, 135, 1975.

Bacon, C.F., "Blowout of a Geothermal Well," Calif. Geol. 29 (.1), 13, 1976.

Bolten, R.S., "Management of a Geothermal Field," in Geothermal Energy, H.C.H. Armstead, ed., Unesco, Paris, 1973.

Brown, F.C., "Control of $\mathrm{H}_{2} \mathrm{~S}$ from Geothermal Power Plants by Steam Scrubbing with Copper Sulfate Solution," Proceedings of the U.S. DOE Environmental Control Symposium, Washington, D.C., November 28-30, $\underline{1978,}$ in press.

Crow, N.B. and P.W. Kasameyer, "Monitoring Natural Subsidence and Seismicity in the Imperial Valley as a Basis for Evaluating Potential Impacts of Geothermal Production," Geothermal Resources Council Trans. 2, 125, 1978.

Cummings, R.G., G.E. Morris, J.W. Tester, and R.L. Bivins, "Electricity from Hot Dry Rock Geothermal Energy: Technical and Economic Issues," LA-UR-78-1374, Los Alamos Scientific Laboratory, 1978.

Ermak, D.L. and P.L. Phelps, "An Environmental Overview of Geothermal Development: The Geysers-Calistoga KGRA. Volume 1. Issues and Recommendations," UCRL-52496, Lawrence Livermore Laboratory, 1978.

Ermak, D.L., "A Scenario for Geothermal Electric Power Development in Imperial Valley," Energy 3, 203, 1978.

Gudiksen, P.H., M.C. Axelrod, D.L. Ermak, K.C. Lamson, and R. Lange, "A Methodology for Assessing the Potential Impact on Air Quality Resulting from Geothermal Resource Development in the Imperial Valley," Proceedings of the International Clean Air Conference, Brisbane, Australia, May 15-19, 1978, E.T. White, T. Hetherington, and D.R. Thiele, eds., Ann Ärbor Science Publishers, Ann Arbor, Michigan, 1978.

Gutschick, V. and K. Rea, "Environmental Assessment of Dissolved Gases in LASL's Hot Dry Rock Geothermal Source Demonstration Project," Geothermal Resources Council Trans. 2, 249, 1978. 


\section{BIBLIOGRAPHY (Continued)}

Hankins, B.E., R.E. Chàvanne, R.A. Ham, O.C. Karkalits and J.I. Palermo, "Chemical Analysis of Water from the World's First Geopressured-Geothermal Well," Geothermal Resources Council Trans. 2, 253, 1978.

Harrar, J.E., L.E. Lorensen, C.H. Otto, Jr., S.B. Beutscher, and G.E. Tardiff, "Effects of Organic Additives on the Formation of Solids from Hypersaline Geothermal Brine,". Geothermal Resources Council Trans. 2, $259,1978$.

Imperial County Planning Department, El Cențro, Calif., "Geothermal Resource Element to the; General Plan," 1977.

Interagency Geothermal Coordinating Council, "Geothermal Energy, Research, Development and Demonstration Program, DOE/ET-0039/1 (IGCC-3), U.S. Department of Energy, 1978.

Jacobsen, W.O., "Operational History of the Geothermal Loop Experimental Facility at the Salton Sea KGRA," Geothermal Resources Council Trans. $2,325,1978$.

Johnson, C.E. and D.M. Hadley, "Tectonic Implications of the Brawley Earthquake Swarm,. Imperial Valley, California, January 1975," preprint of a paper given at the Fall Meeting, American Geophysical Union, San Francisco, December 1.975.

Karkalits, O.C. and B.E. Hankins, "Chemical Analysis of Dissolved Natural Gas in Water from the World's First Geopressured Geothermal Well," Geothermal Resources Council Trans. 2, 351, 1978.

Lawrence Berkeley Laboratory, "Geothermal Subsidence Research Program Plan," LBL-5983, 1977.

Lofgren, B.E., "Measuring Ground Movement in Geothermal Areas of Imperial Valley, California," Proc. Conf. Res. Dev. Geothermall Energy Resources, Pasadena, California, September 23-25, 1974, NSF-RA-N-74-159, National Science Foundation, 1974.

Martin, J.B., "Environmental, Safety, and Health Standards Identification for Geothermal Energy," PNL-2583, Battelle Pacific Northwest Laboratories, 1979.

Muffler, L.J.P., ed., "Assessment of Geothermal Resources of the United States--1978," Circular 790, U.S. Geological Survey, 1978.

Newchurch, E.J., C.F. Bryan, D.P. Harrison, R.A. Muller, R.E. Wilcox, A.L. Bachman, J.P. Newman, K.J. Cunningham, R.K. Hilding, and J.A. Rehage, "A Plan for the Long Term Environmental Assessment of Geopressured Resource Development in the Louisiana Gulf Coast Region," UCRL-13913, Lawrence Livermore Laboratory, 1978. 


\section{BIBLIOGRAPHY (Continued)}

Pacific Gas and Electric Co., "Amended Environmental Data Statement. Geysers Unit 13," 1975.

Pettit, R.A., "Environmental Monitoring for the Hot Dry Rock" Geothermal Energy Development Project. Annual Report for the Period July 1975 - June 1976,". LA-6504-SR, Los Alamos Scientific Laboratory, 1976.

Phelps, P.L. and L.R. Anspaugh, "Imperial Valley Environmental Project: Progress Report," UCRL-50044-76-1, Lawrence Livermore Laboratory, 1976.

Pimentel, K.D., R.R. Ireland, and G.A. Tompkins, "Chemical Fingerprints to Assess the Effects of Geothermal Development on Water Quality in Imperial Valley," Geothermal Resources Council Trans. 2, 527, 1978.

Robertson, D.E., E.A. Crecelius, J.S. Fruchter, and J.D. Ludwick, "Mercury Emissions from Geothermal Power Plants," Science 196, 1094, 1977.

U.S. Department of Energy, "Environmental Readiness Document. Hydrothermal Electric and Direct Heat," DOE/ERD-0005, 1978.

U.S. Department of Energy, "Development Plans for Geothermal Energy," in preparation.

Wilson, J.S., J.R. Hamilton, J.A. Manning, and P.E. Muehlberg, "Environmental Assessment of Geopressured Waters and Their Projected Uses," EPA-600/7-77-039, Environmental Protection Agency, 1977. 


\section{APPENDIX A}

\section{SETTING RESEARCH PRIORITIES "FOR}

\section{'ENVIRONMENTAL', HEALTH, AND SAFETY'RESEARCH}

In addition to the rationale described in Section IIIA; three other factors require consideration in defining, setting priorities for, and scheduling environmental research. Each is discussed briefly below.

\section{A. REGULATORY IMPETUS}

When Federal, State or local regulations or standards exist explicitly for new technologies, or implicitly through general regulation of some of the potential emissions or safety concerns,. a ranking of possible impacts has already been performed by the regulating agency. High priority must be given to research directed toward determining the potential for compliance with existing or imminent regulations. "Generally, when adequate regulations and standards exist, research is directed more toward identifying cost-effective compliance options (control technology) than determining impacts of alternative levels of control. Federal regulations concerning air and water emissions, their resulting environmental effects, solid waste disposal, toxic material handling, and occupational safety and health matters applicable to phases of geothermal energy systems technology include the following:

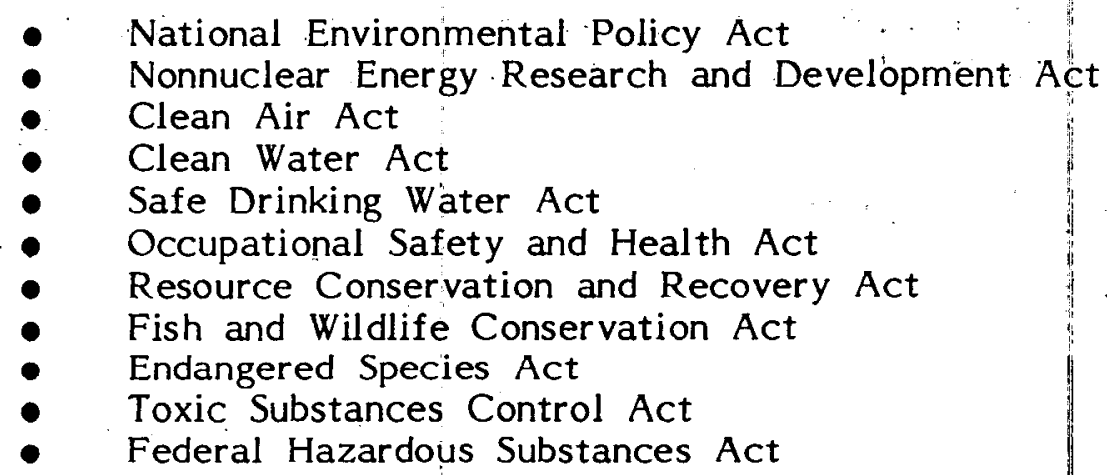

In addition to such regulation on the Federal level, geothermal energy systems technology development will be impacted significantly by State and local regulations. These consist primarily of water law, zoning, and land use controls, all of which tend to be administered on the local and State level, except in those cases where geothermal energy resources are located on federally owned land. Zoning regulations restrict the ways in which owners may develop or use their land in the interest of the public health, safety, or general welfare. Water law, for example, appropriative and riparian doctrine, regulates and will determine the manner of water use in areas of geothermal resources development. Both of these regulatory mechanisms will explicitly or implicitly contribute toward setting environmental research priorities for geothermal resources development. 


\section{B. ENVIRONMENTAL RESOLUTION TIME VERSUS PUBLIC UTILIZATION TIME}

A primary consideration for determining research needs is the schedule of deployment for the particular technology. The objective of the EDP is to plan environmental research so that issues are resolved before a technology is extensively utilized. Therefore, whenever it is estimated that the time required to resolve an environmental issue (environmental resolution time) through $R D \& D$ is greater than or equal to the time before the technology is available to the public, that issue has priority.

\section{COST-EFFECTIVENESS}

Another approach in determining priorities is to consider the commonality of problems among diverse technologies. Researching the problems of one particular technology may resolve similar problems involving other technologies. Such an approach is cost-effective. 


\section{APPENDIX B}

SUMMARY OF COMPLETED, CURRENT, AND PLANNED ENVIRONMENTAL RESEARCH PROJECTS

Tables B-1, B-2, and B-3 summarize research that addresses the environmental effects of geothermal energy systems technology development: The projects described here address concerns as identified in Tables 3-3, 3-4, and 3-5. 
Table B-1. Completed, Current, and Planned Research Projects for Hydrothermal Systems

Projects Listed are Keyed to Concerns and Requirements in Table 3-3

\begin{tabular}{|c|c|c|c|c|c|c|}
\hline CONCERN & $\begin{array}{l}\text { REQUIREMENT } \\
\text { NUMBER }\end{array}$ & $\frac{\text { SPONSORING AGENCY/OFFICE* }}{\text { PROJECT TITLE }}$ & $\begin{array}{c}\text { PERFORMING } \\
\text { ORGANIZATION* }\end{array}$ & STATUS & $\begin{array}{l}\text { START } \\
\text { DATE }^{+}\end{array}$ & $\begin{array}{l}\text { COMPL. } \\
\text { DATE }^{+}\end{array}$ \\
\hline $\begin{array}{l}\text { 1. ReTease of Air } \\
\text { borne Effluent }\end{array}$ & $\begin{array}{l}1.1,1.3,1.5 \\
1.1,1.2 \\
1.1,1.3 \\
1.1,1.2 \\
1.1,1.3 \\
1.1 \\
1.1,1.2,1.4 \\
1.4 \\
1.6 \\
1.6 \\
1.5 \\
1.6 \\
1.1 \\
\vdots\end{array}$ & $\begin{array}{l}\text { DOE/EV } \\
\text { Air Quality Impacts of Geothermal Development in } \\
\text { Cal ifornia (IVEP, Geysers) } \\
\text { Atmospheric Characterization } \\
\text { Trace Metal Characterization and Speciation in } \\
\text { Geothermal Effluents } \\
\text { Heavy Metal and Noxious Gas Emissions } \\
\text { Geothermal Tracer Experiment } \\
\text { Poilutant Transport in Complex Terrain } \\
\text { Effects of } \mathrm{H}_{2} \mathrm{~S} \text { on Vegetation } \\
\text { Toxic Effects of Geothermal Effluents } \\
\text { Evaluation of } \mathrm{H}_{2} \mathrm{~S} \text { Control Technology for Geothermal } \\
\text { Energy SourceS } \\
\text { D0E/DGE. } \\
\mathrm{H}_{2} \mathrm{~S} \text { Removal from Brine - Direct Oxidation } \\
\text { Removal of } \mathrm{H}_{2} \mathrm{~S} \text { from Geothermal Steam by Catalytic } \\
\text { Oxidation } \\
\mathrm{H}_{2} \mathrm{~S} \text { Control, CuSO Scrubbing } \\
\text { EPA } \\
\text { Monitoring Guides for } \mathrm{H}_{2} \mathrm{~S} \text { and Noncondensable } \\
\text { Hazardous Gaseous Emission/Geothermal } \\
\quad \\
\text {. }\end{array}$ & 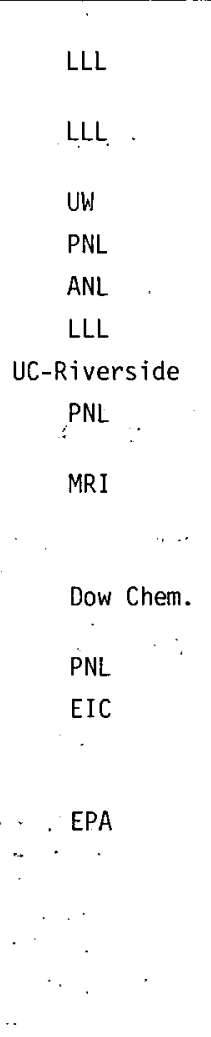 & $\begin{array}{l}\text { Current } \\
\text { Completed } \\
\text { Completed } \\
\text { Current } \\
\text { Planned. } \\
\text { Current } \\
\text { Current } \\
\text { Current } \\
\text { Current } \\
\qquad \because \\
\text { Completed } \\
\text { Current } \\
\text { Current } \\
\text { Current }\end{array}$ & $\begin{array}{l}1977 \\
1978 \\
1975 \\
1980 \\
1979 \\
1978 \\
1978 \\
1978 \\
\\
1976 \\
1977 \\
1978\end{array}$ & $\begin{array}{l}1978 \\
\vdots \\
1978 \\
1980 \\
1980 \\
1982 \\
1980 \\
1980 \\
1979 \\
\\
1978 \\
1982 \\
1980 \\
.- \\
1979 .\end{array}$ \\
\hline
\end{tabular}


Table B-1. Completed, Current, and Planned Research Projects for Hydrothermal Systems (Continued)

\section{Projects Listed are Keyed to Concerns and Requirements in Table 3-3}

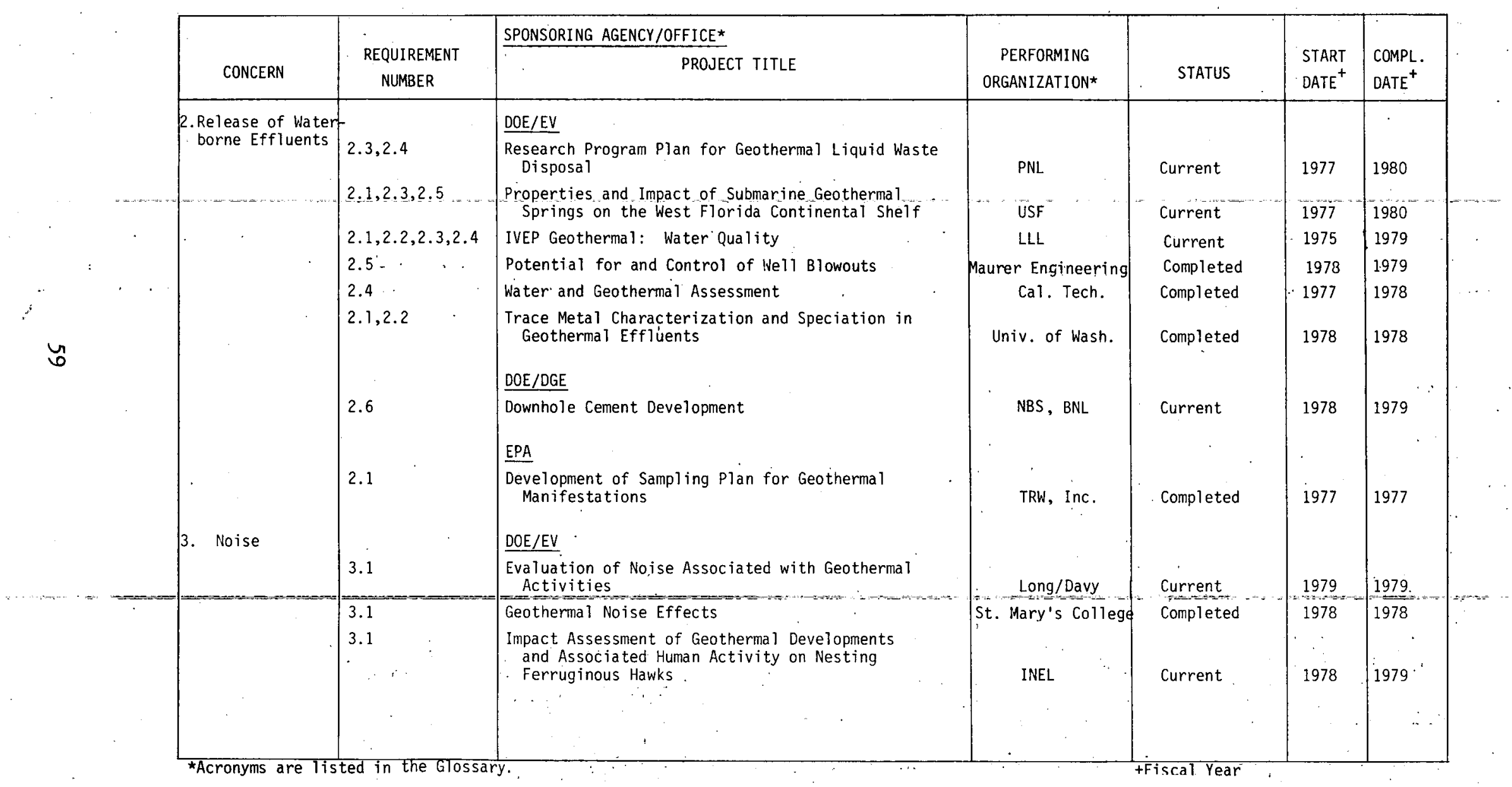


Table B-1. Completed, Current, and Planned Research Projects for Hydrothermal Systems (Continued)

Projects Listed are Keyed to Concerns and Requirements in Table 3-3.

\begin{tabular}{|c|c|c|c|c|c|c|}
\hline CONCERN & $\begin{array}{l}\text { REQUI REMENT } \\
\text { NUMBER }\end{array}$ & $\frac{\text { SPONSORING AGENCY/OFFICE* }}{\text { PROJECT TITLE }}$ & $\begin{array}{l}\text { PERFORMING } \\
\text { ORGANIZATION* }\end{array}$ & STATUS & $\begin{array}{l}\text { START } \\
\text { DATE }^{+}\end{array}$ & $\begin{array}{l}\text { COMPL. } \\
\text { DATE }^{+}\end{array}$ \\
\hline $\begin{array}{l}\text { 3. Noise (cont'd) } \\
\text { 4. Subsidence }\end{array}$ & $\begin{array}{l}3.1 \\
3.1 \\
4.1,4.2,4.3 \\
4.1,4.3 \\
4.1,4.2,4.3 \\
4.1,4.2,4.3 \\
5.1 \\
5.2 \\
5.1,5.2 \\
5.1,5.2 \\
5.1 \\
5.1,5.2 \\
5.1,5.2 \\
5.1,5.2\end{array}$ & $\begin{array}{l}\text { DOE/DGE } \\
\text { Noise Control Program } \\
\text { Peregrine Falcon Study } \\
\text { DOE/EV } \\
\text { IVEP - Geothermal Subsidence and Seismicity } \\
\text { Assess. Effectiveness of Subsidence/Seismic Control } \\
\text { Techniques } \\
\text { DOE/DGE } \\
\text { Geothermal Subsidence Research Program } \\
\text { USGS } \\
\text { Geothermal Investigations, Subsurface Env. Impact } \\
\text { DOE/EV } \\
\text { Potential for Land Seismic Activity } \\
\text { ASsess Effectiveness of Subsidence/Seismic Control } \\
\text { Techniques } \\
\text { IVEP - Geothermal Subsidence and Seismicity } \\
\text { DOE/DGE } \\
\text { Seismic Monitoring at The Geysers Geothermal. Field } \\
\text { Induced Seismicity - RHS Utah } \\
\text { Induced Seismicity - The Geysers } \\
\text { Induced Seismicity - Cerro Prieto } \\
\text { Induced Seismic Research Program }\end{array}$ & $\begin{array}{l}\text { TBD } \\
\text { GRIPS Commission } \\
\text { LLL } \\
\text { TBD } \\
\text { LBL } \\
\text { USGS, Ca7if. } \\
\text { TBD } \\
\text { TBD } \\
\text { LLL } \\
\text { USGS } \\
\text { Univ. of Utah } \\
\text { USGS } \\
\text { LBL } \\
\text { Nevada Operations } \\
\text { Office }\end{array}$ & $\begin{array}{l}\text { Current } \\
\text { Completed } \\
\text { Planned } \\
\text { Planned } \\
\text { Completed } \\
\text { Completed } \\
\text { Current } \\
\text { Current } \\
\text { Current } \\
\text { Current }\end{array}$ & $\begin{array}{c}1979 \\
1980 \\
1977 \\
\ddots \\
1977 \\
1978 \\
1977 \\
1978 \\
1978\end{array}$ & $\begin{array}{l}1978 \\
1982 \\
1979 \\
1979 \\
1982\end{array}$ \\
\hline
\end{tabular}

*Acronyms are listed in the Glossary. 
Table B-1. Completed, Current, and Planned Research. Projects for Hydrothermal Systems (Continued)

Projects Listed are Keyed to Concerns and Requirements in Table 3-3

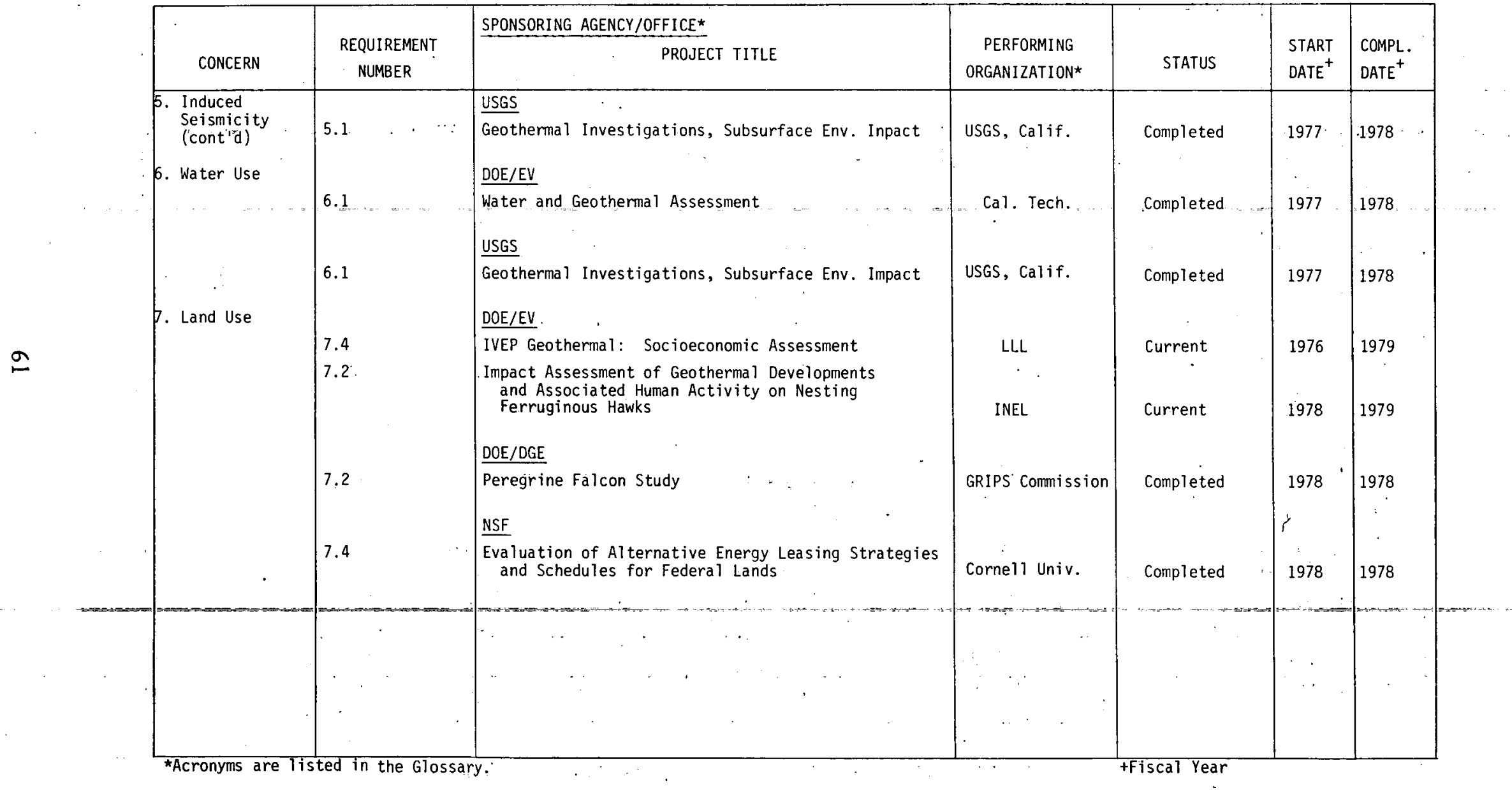


Table B-1. Completed, Current, and Planned Research Projects for Hydrothermal Systems (Continued)

Projects Listed are Keyed to Concerns and Requirements in Table 3-3

\begin{tabular}{|c|c|c|c|c|c|c|}
\hline CONCERN & $\begin{array}{l}\text { REQUIREMENT } \\
\text { NUMBER }\end{array}$ & $\frac{\text { SPONSORING AGENCY /OFFICE^ }}{\text { PROJECT TITLE }}$ & $\begin{array}{l}\text { PERFORMING } \\
\text { ORGANIZATION* }\end{array}$ & STATUS & $\begin{array}{l}\text { START } \\
\text { DATE }^{+}\end{array}$ & $\begin{array}{l}\text { COMPL. } \\
\text { DATE }^{+}\end{array}$ \\
\hline $\begin{array}{l}\text { 3. Social Services } \\
\text { and Community } \\
\text { Structure. }\end{array}$ & 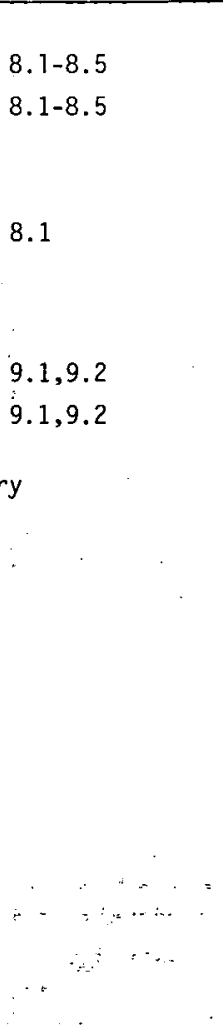 & 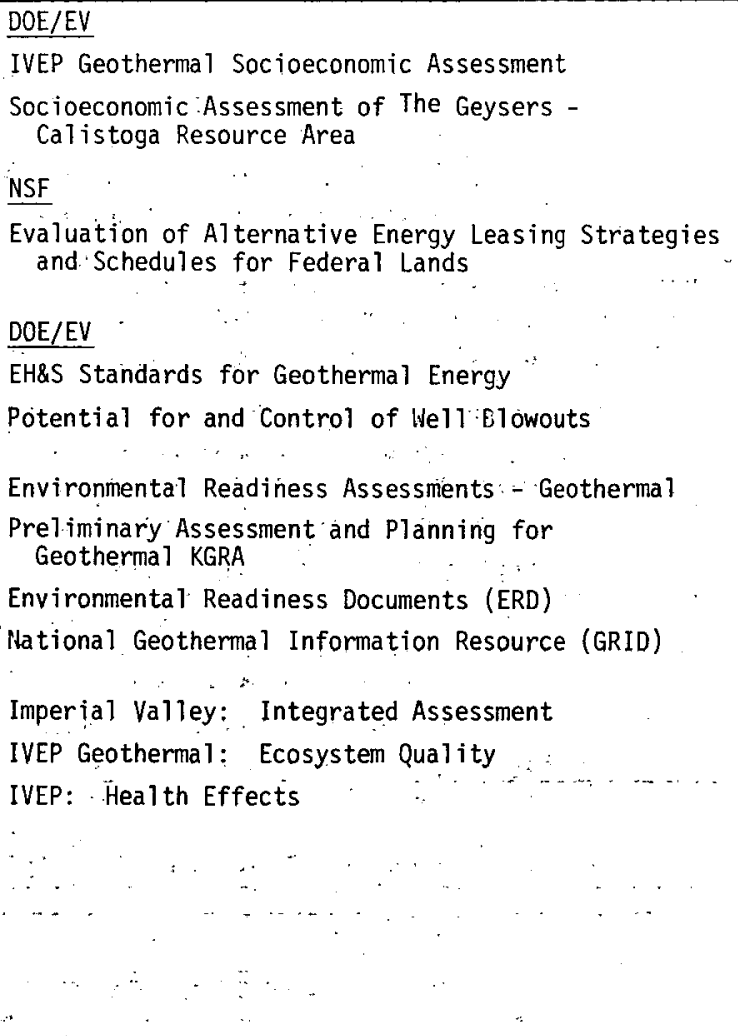 & $\begin{array}{c}\text { Cornel1 Univ. } \\
\text { PNL } \\
\text { Maurer Engineering } \\
\text { LLL } \\
\text { LLL. } \\
\text { LLL } \\
\text { LBL } \\
\text { LLL } \\
\text { LLL } \\
\text { LLL } \\
\end{array}$ & $\begin{array}{l}\text { Current } \\
\text { Completed } \\
\text { Planned } \\
\text { Current } \\
\text { Current } \\
\text { Completed } \\
\text { Current } \\
\text { Current } \\
\text { Current - }\end{array}$ & $\begin{array}{r}1978 \\
1977 \\
1978 \\
1980 \\
1977 \\
1978 \\
1976 \\
1977 \\
1976 \\
1977\end{array}$ & $\begin{array}{l}1979 \\
1979 \\
\\
1981 \\
\\
1981 . \\
1980 \\
1978 \\
\\
1979 \\
1979 \\
1980\end{array}$ \\
\hline
\end{tabular}


Table B-1. Completed, Current, and Planned Research Projects for Hydrothermal Systems (Continued)

Projects Listed are Keyed to Concerns and Requirements in Table 3-3

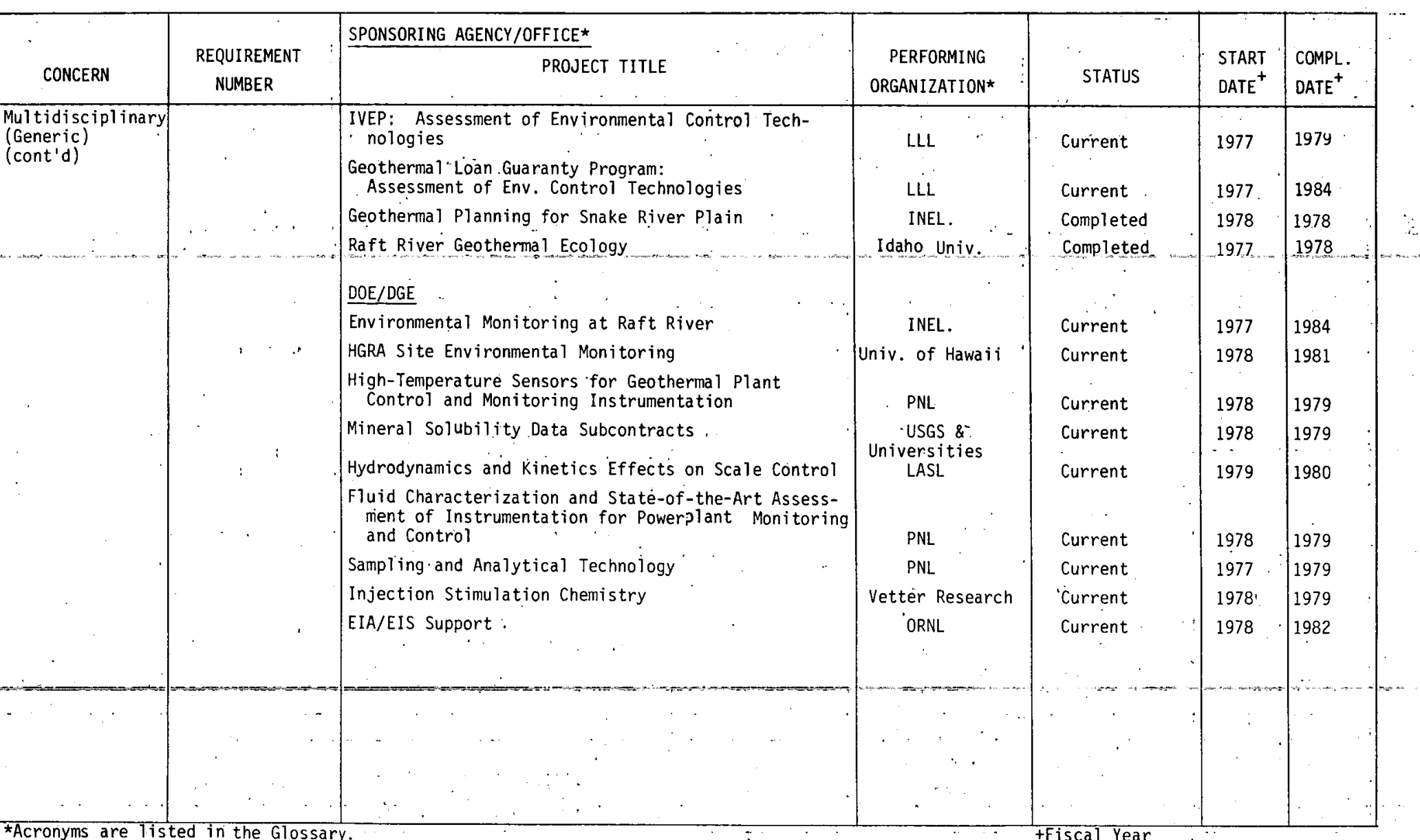


Table B-2. Completed, Current, and Planned Research Projects for Geopressured Systems

Projects Listed are Keyed to Concerns and Requirements in Table 3-4

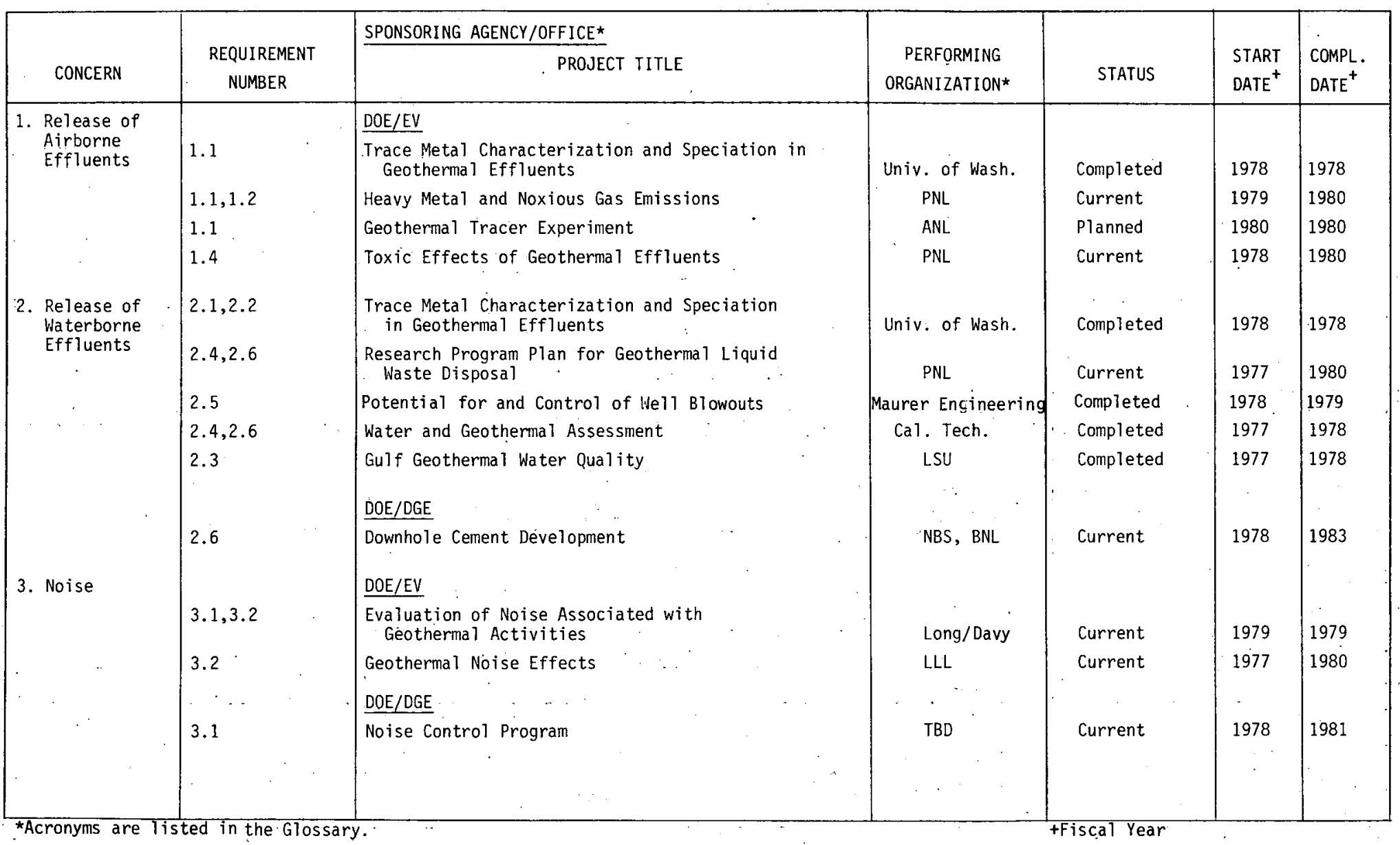


Table B-2. Completed, Current, and Planned Research Projects for Geopressured Systems (Continued)

Projects Listed are Keyed to Concerns and Requirements in Table 3-4

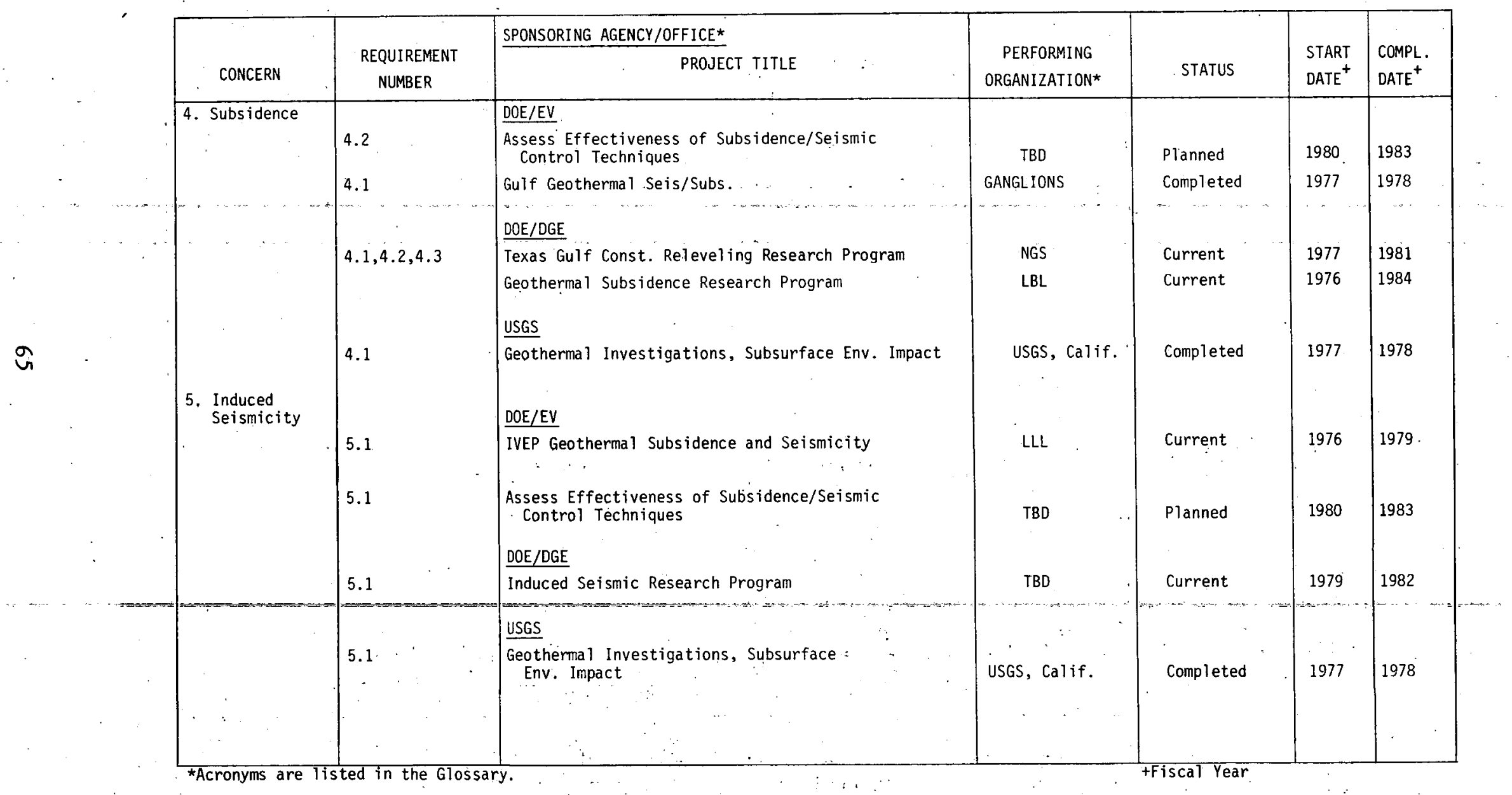


Table B-2. Completed, Current, and Planned Research Projects for Geopressured Systems (Continued)

Projects Listed are Keyed to Concerns and Requirements in Table 3-4

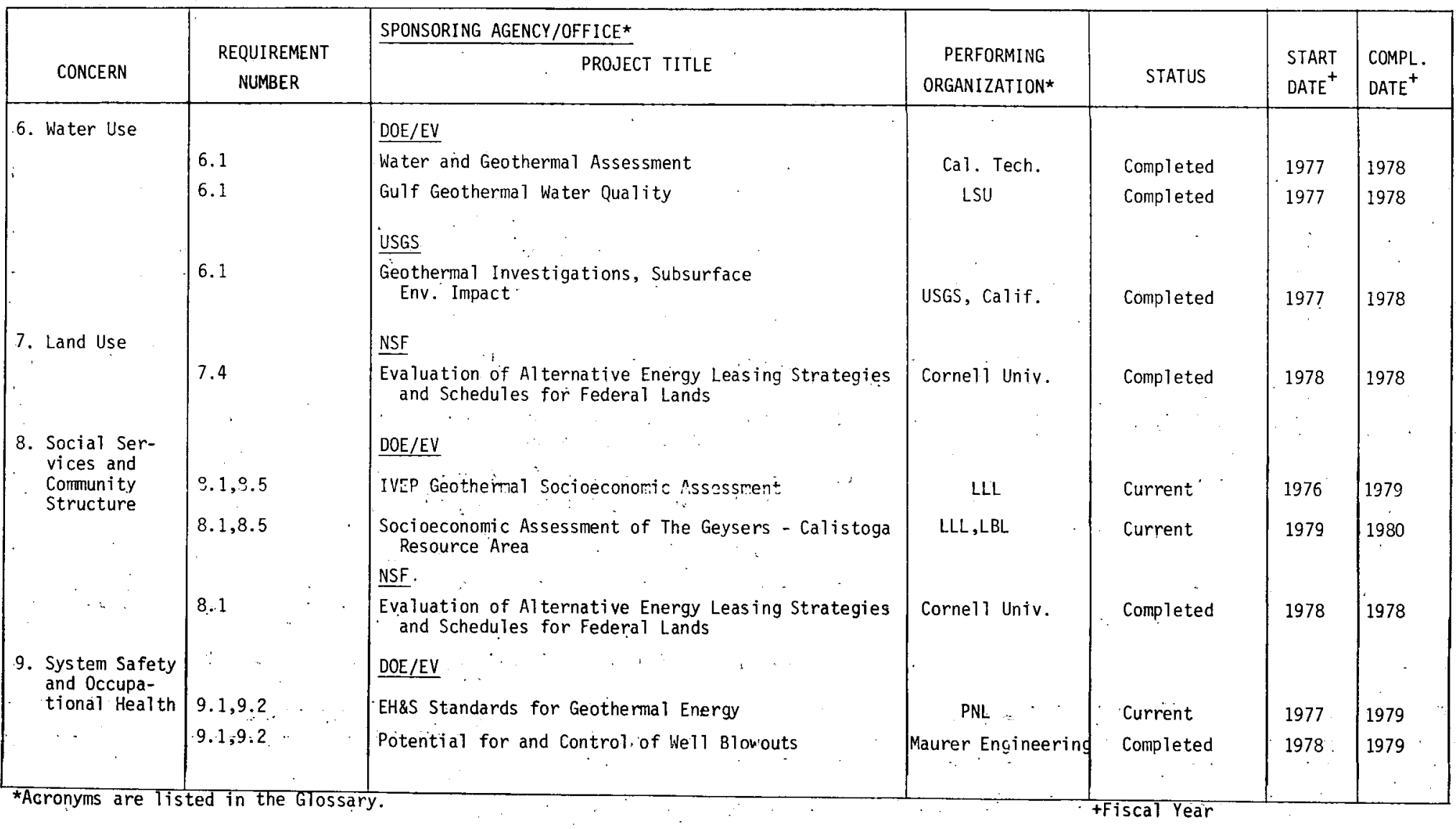


Table B-2. Completed, Current, and Planned Research Projects for Geopressured Systems (Continued)

Projects Listed are Keyed to Concerns and Requirements in Table 3-4

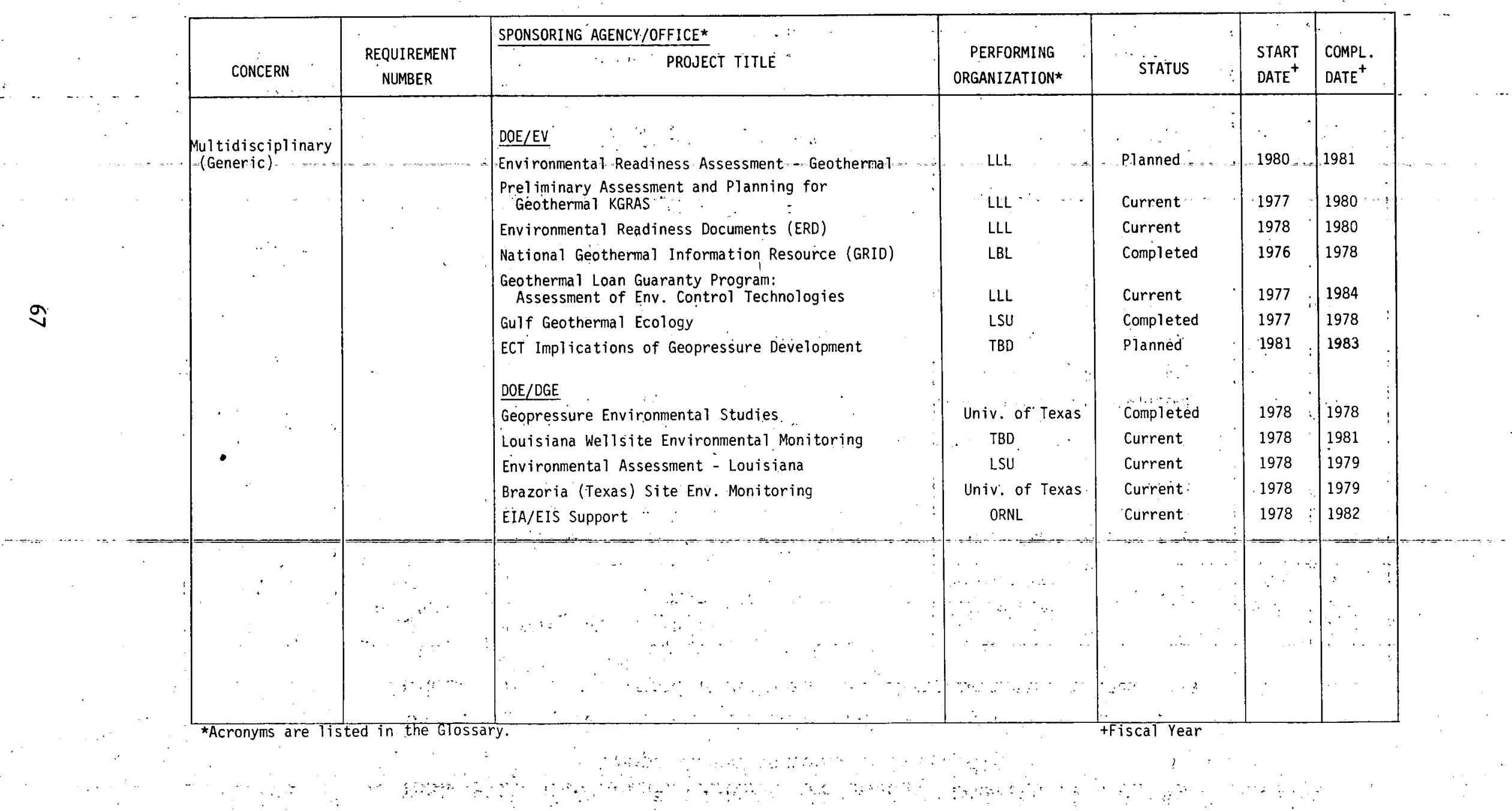


Table B-3. Completed, Current, and Planned Research Projects for Hot Dry Rock Systems

Projects Listed are Keyed to Concerns and Requirements in Table 3-5

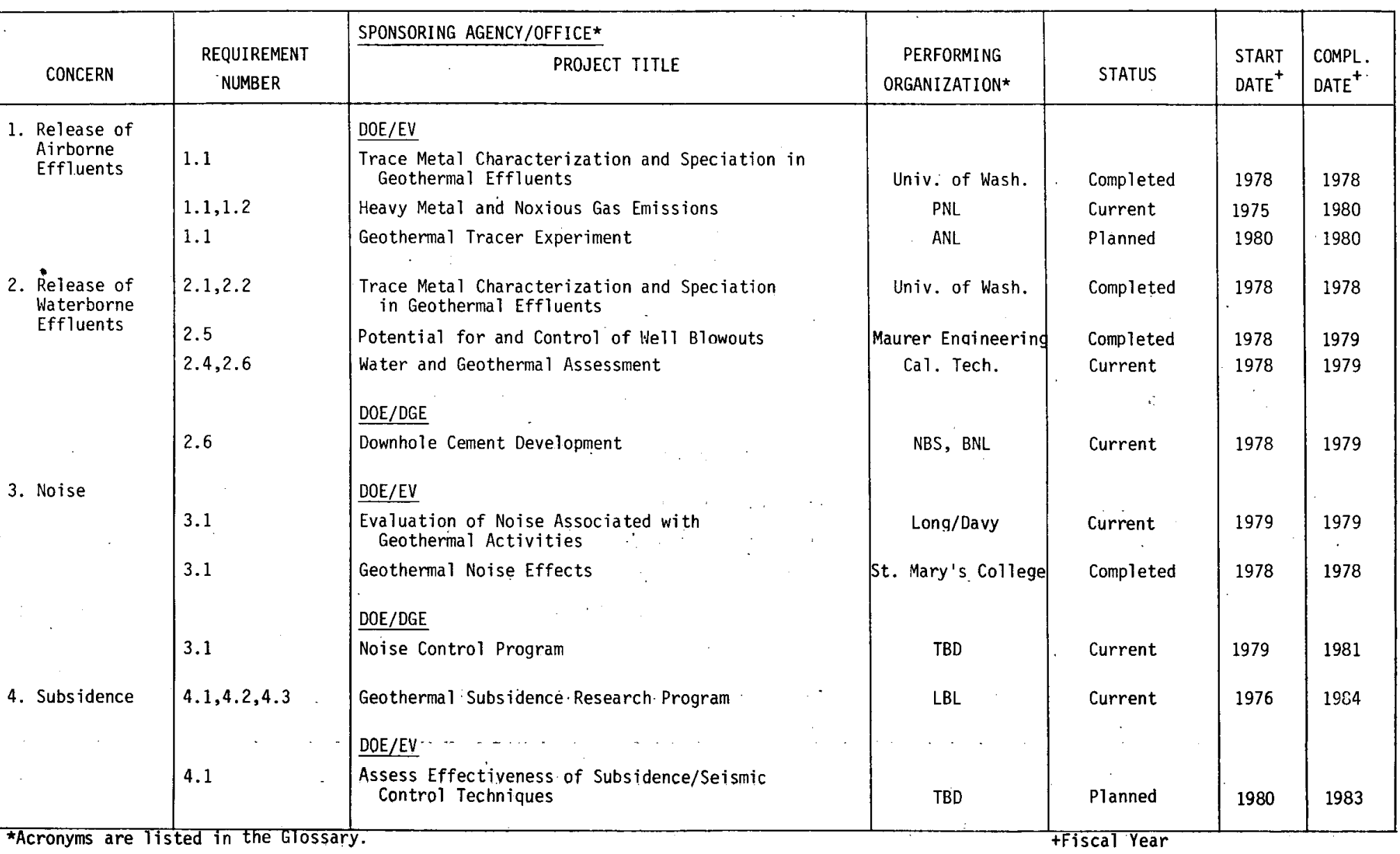


Table B-3. Completed, Current, and Planned Research Projects for Hot Dry Rock Systems (Continued)

Projects Listed are Keyed to Concerns and Requirements in Table 3-5

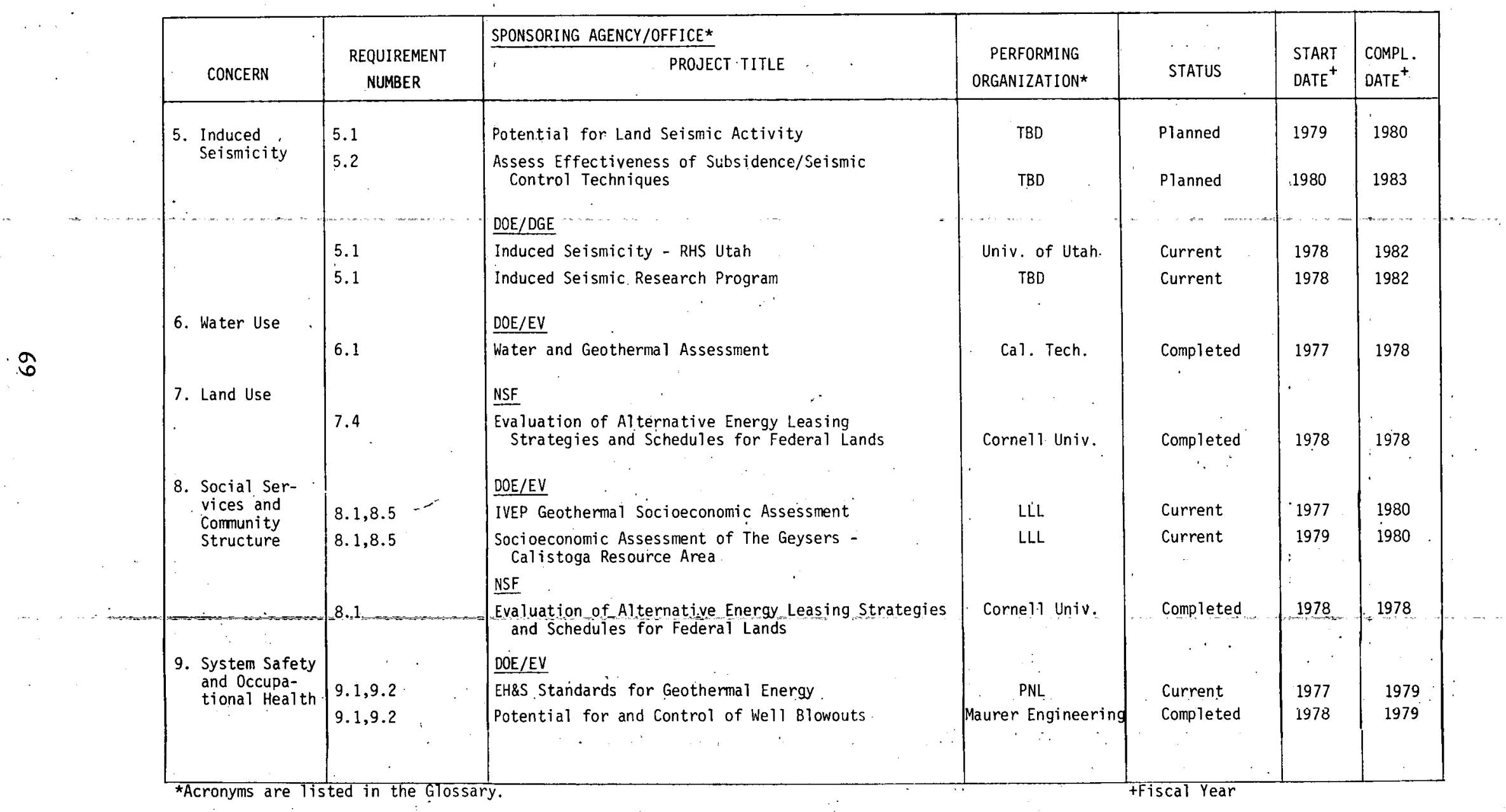


Table B-3. Completed, Current, and Planned Research Projects for Hot Dry Rock Systems (Continued)

Projects Listed are Keyed to Concerns and Requirements in Table 3-5

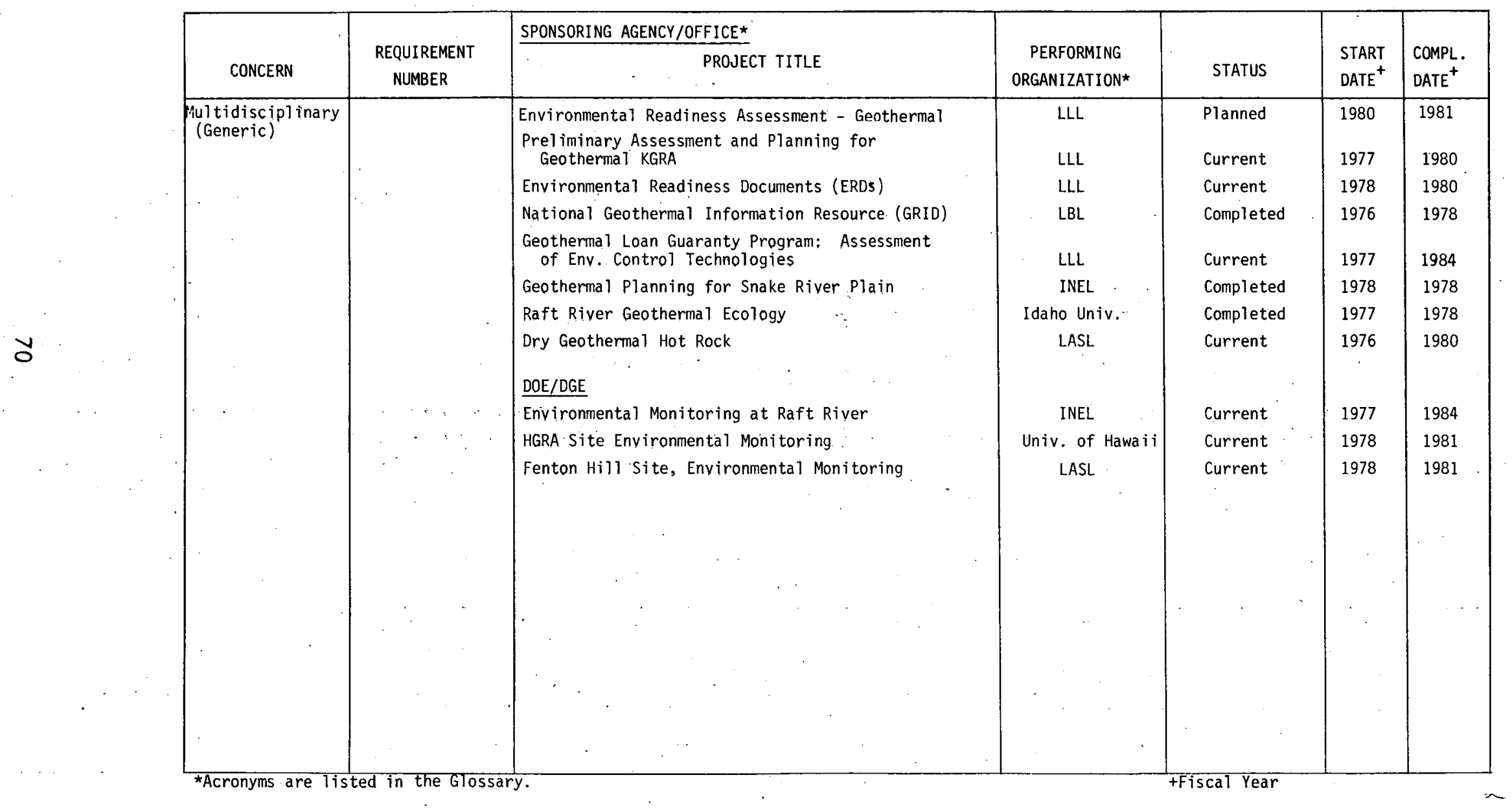


ANL, : Argonne National Laboratory

BNL Brookhaven National Laboratory

DGE Division of Geothermal Energy

DOC Department of Commerce

DOE $\quad$ Department of Energy

DOI Department of the Interior

EA Environmental Assessment

EDP Environmental Development Plan

EH\&S environmental, health, and safety

EIS Environmental Impact Statement

EPA Environmental Protection Agency

ERD Environmental Readiness Document

ET Office of Energy :Technology

ETS Office of Energy Technology, Solar, Geothermal, Electric, and

EV Office of Environment

GECC Geothermal Environmental Coordination Committee

GRIPS Geothermal Research Impacts Project Study Commission

HSL

INEL

KGRA

Health Services Laboratory, Idaho Falls

LASL

LBL

LLL

LSU

MRI

NBS

NEPA

NSF

ORNL

OSHA

PNL

RA

$R \& D$

TBD

$\mathrm{UC}$

USF

USGS

UW

Idaho National Engineering Laboratories

known geothermal resource area

Los Alamos Scientific Laboratory

Lawrence Berkeley Laboratory

Lawrence Livermore Laboratory

Louisiana State University

Midwest Research Institute

National Bureau of Standards

National Environmental Policy Act

National Science Foundation

Oak Ridge National Laboratory

Occupational Health and Safety Administration

Pacific Northwest Laboratory

- Office of Resource Applications

research and development

to be determined

University of California

University of San Francisco

U.S. Geological Survey

University of Washington 